Biochemical, functional and pharmacological characterization of novel bifunctional peptide ligands and nociceptin variants

PhD thesis

Anna Erdei

Supervisors:

Dr. Sándor Benyhe, Prof. Dr. Anna Borsodi

Institute of Biochemistry

Biological Research Centre of the Hungarian Academy of Sciences

and

Theoretical Medicine Doctoral School,

University of Szeged, Faculty of Medicine

Szeged, Hungary

2019 


\section{This thesis is based on the following publications:}

I. Erdei AI, Borbely A, Magyar A, Taricska N, Perczel A, Zsiros O, Garab G, Szucs E, Otvos F, Zador F, Balogh M, Al-Khrasani M, Benyhe S. Biochemical and pharmacological characterization of three opioid-nociceptin hybrid peptide ligands reveals substantially differing modes of their actions. PEPTIDES 99: pp. 205216. (2018)

II. Erdei AI, Borbely A, Magyar A, Szücs E, Ötvös F, Gombos D, Al-Khrasani M, Stefanucci A,Dimmito M.P, Luisi G, Mollica A, Benyhe S. Biochemical and pharmacological investigation of novel nociceptin/OFQ analogues and N/OFQRYYRIK hybrid peptides. PEPTIDES (2018).

\section{Total impact factor: $\mathbf{5 . 7 0 2}$}

\section{Other publications not closely related to this thesis:}

Dadam F, Zador F, Caeiro X, Szucs E, Erdei AI, Samavati R, Gaspar R, Borsodi A, Vivas L.The effect of increased $\mathrm{NaCl}$ intake on rat brain endogenous mu-opioid receptor signalling. JOURNAL OF NEUROENDOCRINOLOGY 30:(4) Paper UNSP e12585. 8 p. (2018)

Stefanucci A, Novellino E, Macedonio G, Dimmito MP, Mirzaie S, Cardoso FC, Lewis R, Zador F, Erdei AI, Dvoracsko S, Tomboly C, Benyhe S, Pieretti S, Minosi P, Mollica A. Design, synthesis and biological profile of mixed opioid agonist/N-VGCC blocker peptides. NEW JOURNAL OF CHEMISTRY 42:(8) pp. 5656-5659. (2018)

Mollica A, Pelliccia S, Famiglini V, Stefanucci A, Macedonio G, Chiavaroli A, Orlando G, Brunetti L, Fer rante C, Pieretti S, Novellino E, Benyhe S, Zador F, Erdei A, Szucs E, Samavati R, Dvoracsko S, Tomboly C, Ragno R, Patsilinakos A, Silvestri R. Exploring the first Rimonabant analog-opioid peptide hybrid compound, as bivalent ligand for CB1 and opioid receptors. JOURNAL OF ENZYME INHIBITION AND MEDICINAL CHEMISTRY 32:(1) pp. 444-451. (2017) 
Stefanucci A, Novellino E, Mirzaie S, Macedonio G, Pieretti S, Minosi P, Szucs E, Erdei AI, Zador F, Benyhe S, Mollica A. Opioid Receptor Activity and Analgesic Potency of DPDPE Peptide Analogues Containing a Xylene Bridge. ACS MEDICINAL CHEMISTRY LETTERS 8:(4) pp. 449-454. (2017)

Stefanucci A, Carotenuto A, Macedonio G, Novellino E, Pieretti S, Marzoli F, Szucs E, Erdei AI, Zador F, Benyhe S, Mollica A. Cyclic Biphalin Analogues Incorporating a Xylene Bridge: Synthesis, Characterization, and Biological Profile. ACS MEDICINAL CHEMISTRY LETTERS 8:(8) pp. 858-863. (2017)

Zador F, Kiraly K, Varadi A, Balogh M, Feher A, Kocsis D, Erdei AI, Lacko E, Zadori ZS, Hosztafi S, Noszal B, Riba P, Benyhe S, Furst S, Al-Khrasani M. New opioid receptor antagonist: naltrexone-14-O-sulfate synthesis and pharmacology. EUROPEAN JOURNAL OF PHARMACOLOGY 809: pp. 111-121. (2017)

Kowalczyk A, Kleczkowska P, Rękawek M, Kulik K, Lesniak A, Erdei A, Borics A, Martin C, Pawlik K, Lipkowski AW, Benyhe S, Makulska-Nowak H, Ballet S, Bujalska-Zadrozny M. Biological evaluation and molecular docking studies of AA3052, a compound containing a $\mu$ selective opioid peptide agonist DALDA and d-Phe-Phe-d-Phe-Leu-Leu-NH2, a substance P analogue. EUROPEAN JOURNAL OF PHARMACEUTICAL SCIENCES 93: pp. 1120. (2016)

Monti L, Stefanucci A, Pieretti S, Marzoli F, Fidanza L, Mollica A, Mirzaie S, Carradori S, De Petrocellis L, Schiano Moriello A, Benyhe S, Zádor F, Szűcs E, Ötvös F, Erdei AI, Samavati R, Dvorácskó S, Tömböly C, Novellino E. Evaluation of the analgesic effect of 4anilidopiperidine scaffold containing ureas and carbamates. JOURNAL OF ENZYME INHIBITION AND MEDICINAL CHEMISTRY 31:(6) pp. 1638-1647. (2016)

Total impact factor: $\mathbf{2 8 . 9 0 7}$ 
TABLE OF CONTENTS

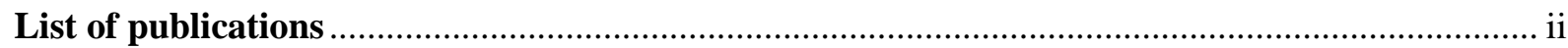

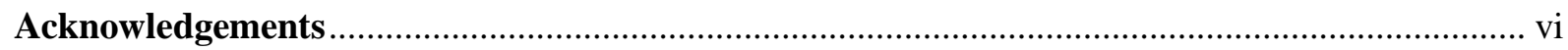

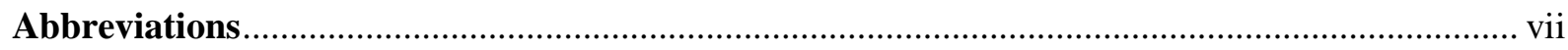

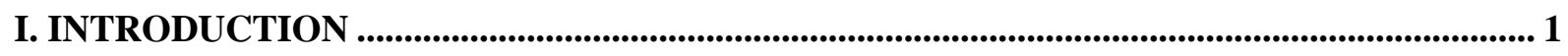

1. Discovery of the NOP receptor and its endogenous ligands .......................................... 1

2. Similarities and dissimilarities between NOP receptor and classical opioid receptors....... 1

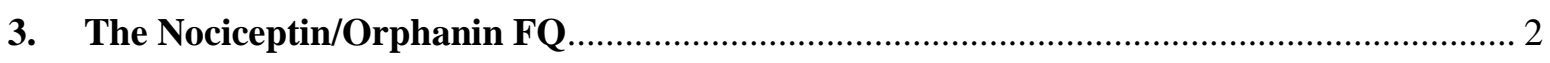

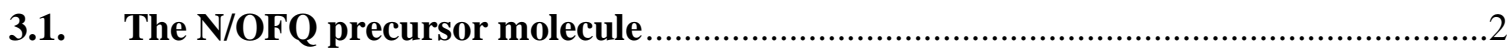

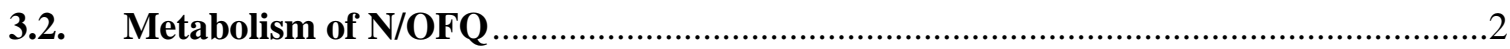

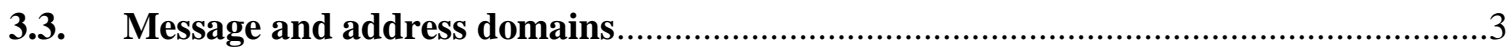

4. Tissue distribution and biological role of the N/OFQ-NOP receptor system ...................... 4

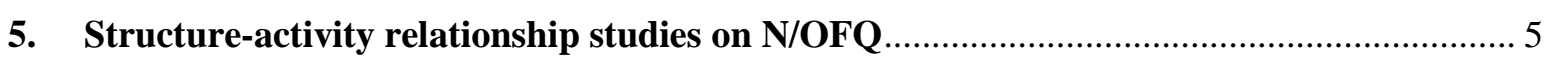

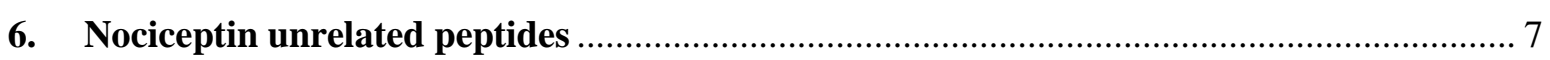

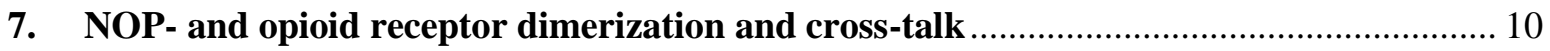

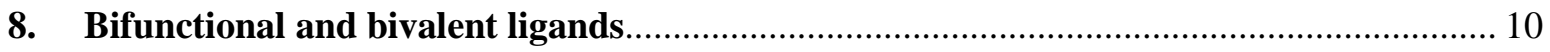

II. AIM OF THE STUDIES........................................................................................................................ 16

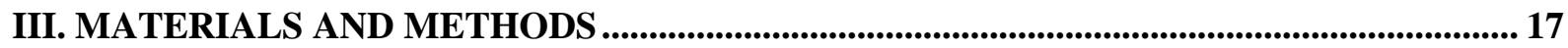

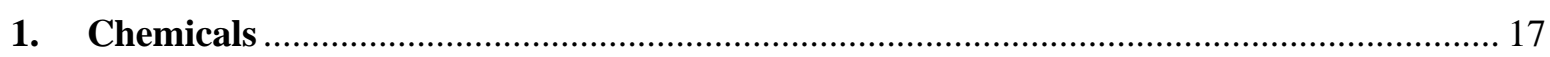

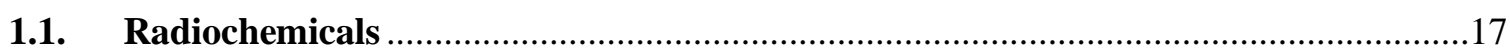

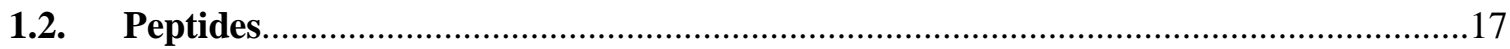

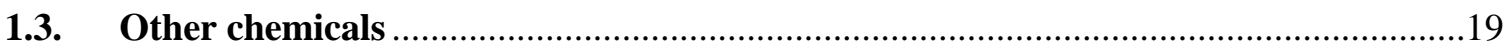

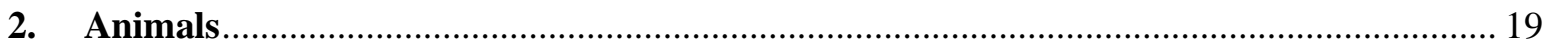

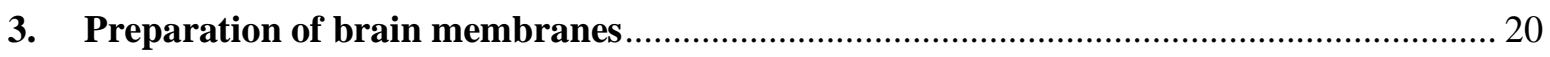

4. In vitro biochemical and functional characterization of tested ligands .............................. 20

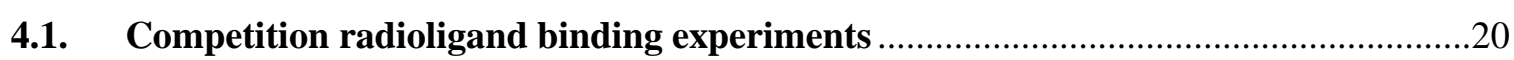

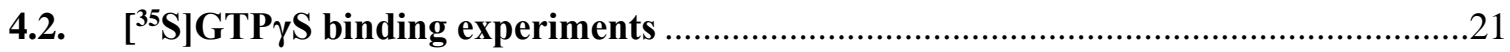

4.3. Mouse vas deferens tissue preparation and MVD bioassays......................................23

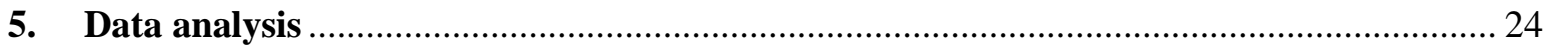

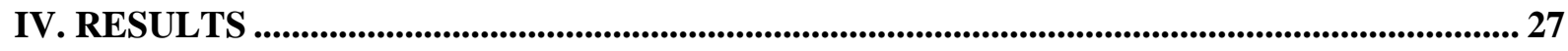

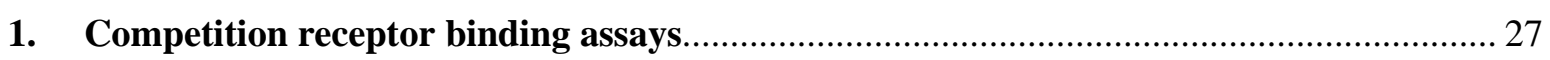

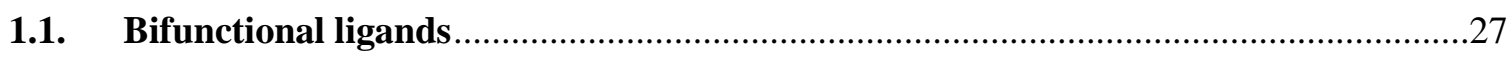

1.2. Nociceptin analogues and nociceptin-RYYRIK hybrid peptides ..................................30

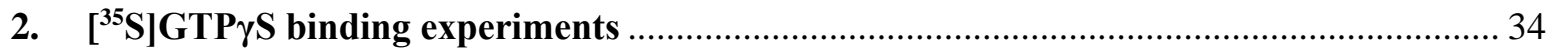




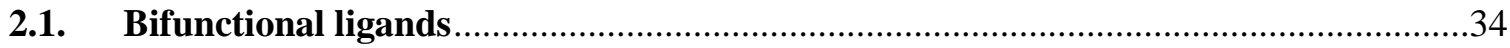

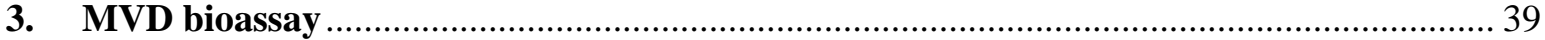

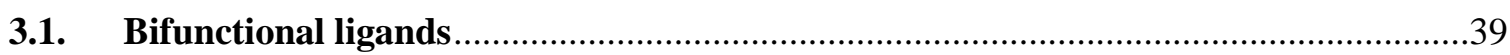

3.2. Nociceptin analogues and nociceptin-RYYRIK hybrid peptides................................ 41

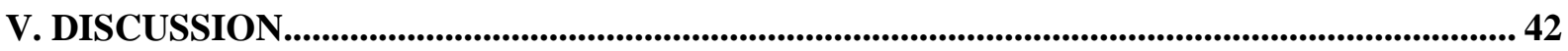

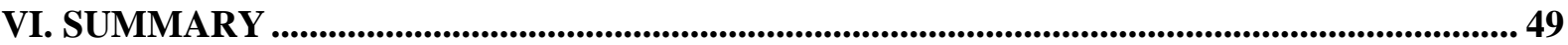

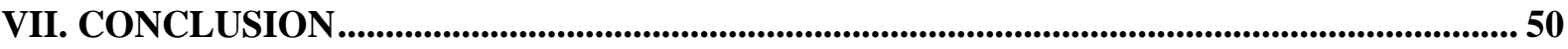

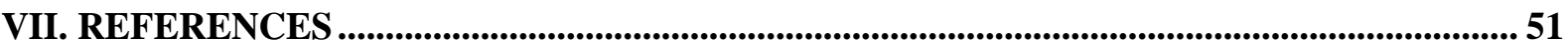




\section{ACKNOWLEDGEMENTS}

I would like to thank Anna Borsodi who gave me the opportunity to start my doctoral studies in this group. Furthermore, I would also like to thank her for the support and the attention I received from her during the time of my $\mathrm{PhD}$ studies.

I am grateful from my heart to Sándor Benyhe for his excellent leadership, help and patience. I am glad that he is such a kind-hearted and educated supervisor, since my knowledge expanded not only in the field of our research but also in other areas.

I am grateful to Mária Wollemann for reading and correcting my thesis tirelessly. I thank her for the references, advices and ideas she gave me. I thank her for the afternoon teas, her trust, the personal stories she shared with me. I also thank her for her sincerity, which helped me improve a lot. I will always remember her.

I am grateful to Ferenc Ötvös for the ligands he designed so we could obtain more information on the relationship between structure and activity. I am grateful to Anna Magyar, Adina Borbély, Adriano Mollica and his lab for the synthesis of the peptides.

I owe thanks to Edina Szücs, who provided me a lot of help in the measurements, and ensured that the lab was always up to date. I thank Ferenc Zádor for giving me his time and helping me with writing papers and fellowship applications. I thank Zsuzsa Benyhe and Márti Kordás for the pleasant conversations and conscientious work so that there was never any interruption in my lab work. Furthermore I thank Adrienn Chrappan for continuously looking after our finances.

I am grateful to Csaba Tömböly, Éva Tóthné Papp and Szabolcs Dvorácskó for the radioligands and the methodological help, and also for making me have a wonderful time here.

I am grateful to Mahmoud Al-Khrasani who gave me the opportunity to acquire new in vitro and in vivo techniques in his lab. I thank him for his patience, trust and friendship he gave me. Furthermore, I thank Mihály Balogh, Ágnes Fehér, Zoltán Zádori and Veronika Pol-Maruzs for helping me know my way around the lab and making my time beautiful. I am also grateful to the entire Biological Research Centre and the Pharmacological and Pharmacotherapeutical Institute of the Semmelweis University, I spent a lovely time there.

I thank my beloved husband Balázs Szalkai, my family and my friends for supporting me during the whole time, because this dissertation would not have been born without them. 


\section{LIST OF ABBREVIATIONS}

\begin{tabular}{|c|c|}
\hline Ac & Acetyl \\
\hline Analogue 1 & $\begin{array}{l}\text { YAFGYPS } \neg \\
\text { Ac-RYYRIK-K-NH }\end{array}$ \\
\hline ANOVA & One-Way Analysis of Variance \\
\hline APN & Aminopeptidase $\mathrm{N}$ \\
\hline BA55 & H-YGGFGGGRYYRIK-NH 2 \\
\hline BA61 & Ac-RYYRIKGGGYGGFL-OH \\
\hline BA62 & H-YGGFRYYRIK-NH ${ }_{2}$ \\
\hline $\mathrm{BE}(2)-\mathrm{c}$ & Human neuroblastoma cells \\
\hline BSA & Bovine serum albumin \\
\hline $\mathrm{C}-24$ & $\begin{array}{l}\text { 1-benzyl-N-[3-[spiroisobenzofuran-1 }(3 \mathrm{H}), 4 \text { '-piperidin-1-yl]propyl] } \\
\text { pyrrolidine-2-carboxamide }\end{array}$ \\
\hline cAMP & Adenosine-3,5'-cyclic monophosphate \\
\hline CCK2 & Cholecystokinin B receptor \\
\hline cDNA & $\begin{array}{l}\text { Complementary DNA copied from an mRNA coding for a protein; it is } \\
\text { inserted into surrogate host cells, causing them to express the protein }\end{array}$ \\
\hline $\mathrm{CHO}$ & 'Chinese hamster ovary' cell line \\
\hline $\mathrm{CPP}$ & Conditioned place preference \\
\hline DADLE & {$\left[\mathrm{d}-\mathrm{Ala}^{2}, \mathrm{~d}-\mathrm{Leu}^{5}\right]$ enkephalin } \\
\hline DAMGO & Tyr-D-Ala-Gly-(NMe)Phe-Gly-ol \\
\hline DOP receptor & $\delta$-opioid receptor \\
\hline DOPr & $\delta$-opioid receptor \\
\hline DR & Dose ratio \\
\hline DRG & Dorsal root ganglia \\
\hline $\mathrm{E}_{\max }$ & $\begin{array}{l}\text { 'Efficacy'; the maximal effect an agonist can elicit in a given } \\
\text { tissue/preparation }\end{array}$ \\
\hline $\mathrm{EC}_{50}$ & $\begin{array}{l}\text { 'Potency'; the agonist molar concentration that produces } 50 \% \text { of the } \\
\text { maximal possible effect of that agonist. }\end{array}$ \\
\hline ECL & Extracellular loop \\
\hline
\end{tabular}


EKC

EP 24.11

GPCR

GTP

GTP $\gamma \mathrm{S}$

$\left[{ }^{35} \mathrm{~S}\right] \mathrm{GTP} \gamma \mathrm{S}$

i.c.v.

IC 50

ICL

IL

IleDelt II

IUPHAR

JTC-801

$\mathrm{K}_{\mathrm{i}}$

$\mathrm{K}_{\mathrm{d}}$

$\mathrm{K}_{\mathrm{e}}$

KGNOP1

KOP receptor

$\mathrm{KOPr}$

MOP receptor

mRNA

MVD

N/OFQ

NK1

NOP receptor

NOPr
Ethylketocyclazocine

Endopeptidase 24.11

G-protein coupled receptor

Guanosin 5'-triphosphate

Guanosine-5'-O-(3-thiotriphosphate)

Guanosine-5'-O-[ $\gamma$-thio] triphosphate

Intracerebroventricular

'Affinity'; the concentration of the competitor producing $50 \%$

displacement in the competion radioligand binding assay.

Intracellular loop

Intracellular

$\mathrm{Ile}^{5,6}$-deltorphin II

International Union of Pharmacology, a nongovernmental organization of national societies functioning under the International Council of Scientific Unions

$\mathrm{N}$-(4-amino-2-methylquinolin-6-yl)-2-(4-

ethylphenoxymethyl)benzamide

Equilibrium inhibition constant; measures a molecule's affinity

Equilibrium dissociation constant of a radioligand-receptor complex

Equilibrium dissociation constant of an antagonist,

$\mathrm{K}_{\mathrm{e}}=[$ molar concentration of antagonist $] / \mathrm{DR}-1$

H-Dmt-D-Arg-Aba-bAla-Arg-Tyr-Tyr-Arg-Ile-Lys- $\mathrm{NH}_{2}$

$\kappa$-opioid receptor

$\kappa$-opioid receptor

$\mu$-opioid peptide receptor

Messenger ribonucleic acid

Mouse vas deferens

Nociceptin/Orphanin FQ

Neurokinin 1

N/OFQ receptor

NOP receptor 
nor-BNI Norbinaltorphimine

NTI Naltrindole

NTS1 and 2 Neurotensin receptor type 1 and 2

NX Naloxone

OP Opioid peptide receptor

ORL-1 receptor Opioid receptor-like 1

P1

Ac-RYYRIKGARKLANQ-NH ${ }_{2}$

P2

H-FGGFTSARKGARKLANQ-NH ${ }_{2}$

P3

H-FGGFRYYRIKSARKLANQ-NH ${ }_{2}$

P4

Ac-RYYRIKSARKLANQ- $\mathrm{NH}_{2}$

P5

Ac-RYYRIKSARKLANQ-OH

P6

Ac-RYYRIKGARKSARKLANQ-OH

P7

Ac-RYYRIKGARKSARK-OH

P8

H-FGGFGGGFGGF-NH ${ }_{2}$

P9

H-FGGFGGGRYYRIK-NH ${ }_{2}$

PAG

Periaqueductal gray

pK i

Antilogarithm of the equilibrium inhibition constant

PPNOC

Prepronociceptin

RO 64-6198 (1S,3aS)-8-(2,3,3a,4,5,6-Hexahydro-1H-phenalen-1-yl)-1-phenyl-1,3,8triazaspiro[4.5]decan-4-one, 8-[(1S,3aS)-2,3,3a,4,5,6-Hexahydro-1Hphenalen-1-yl]-1-phenyl-1,3,8-Triazaspiro[4.5]decan-4-one

RT-PCR Reverse Transcriptase Polymerase chain reaction

S.E.M. $\quad$ Standard error of the mean

SAR Structure-activity relationship

SB-612111 [(-)-cis-1-methyl-7-[[4-(2,6-dichlorophenyl)piperidin-1-yl]methyl]-

6,7,8,9-tetrahydro-5H-benzocyclohepten-5-ol]

SER100 $\rightarrow$ ZP-120

SH-SY5Y Human derived cell line

SIP Small interfering peptide

TEM Tris-HCl-EGTA- $\mathrm{MgCl}_{2}$ buffer

TM Transmembrane 
Tris Tris-(hydroxymethyl)-aminomethane

$\mathrm{U} 50,488 \mathrm{H} \quad$ trans-( \pm -3,4-Dichloro- $N$-methyl- $N$-[2-(1-

pyrrolidinyl)cyclohexyl]benzeneacetamide hydrochloride

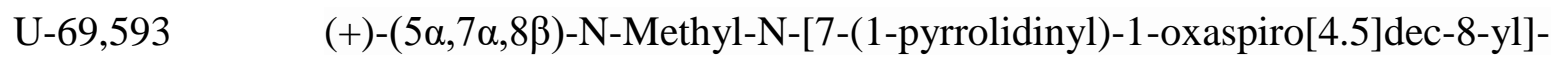
benzeneacetamide

VTA Ventral tegmental area

YGGF Message domain of opioid endopeptides

YGGFL Leucine-enkephalin

ZP-120

Ac-RYYRWKKKKKKK-NH 2 


\section{INTRODUCTION}

\section{Discovery of the NOP receptor and its endogenous ligands}

In 1994, following the discovery of the $\mu$ (MOP), $\delta(\mathrm{DOP})$, and $\kappa(\mathrm{KOP})$ opioid receptors, two research teams identified a so far unknown $G$ protein-coupled receptor, which was termed ORL1 (opioid receptor like 1) ${ }^{1}$. Its name was derived from the fact that although it exhibited significant homology to opioid receptors, it was still unable to bind opioid ligands ${ }^{2-6}$ which meant it could be considered as an "orphan", and not the part of the opioid receptor family in a strict sense.

In the year following the discovery of the receptor, the endogenous ligand of the receptor was successfully identified ${ }^{7}$. To identify the peptide, ORL1 was first cloned and then transfected into Chinese hamster ovary (CHO) cells. Thus the natural peptide of the receptor, the 17-amino-acid nociceptin or N/OFQ (FGGFTGARKSARKLANQ) ligand could be obtained from the brain extract. The name of the ligand was derived from its ability to cause hyperalgesia when it was intracerebroventricularly introduced into mice ${ }^{8}$. The term OFQ suggests that it binds to the 'orphan' opioid receptor with high affinity, and also refers to the sequence itself because the first and last residues of the peptide are $F(P h e)$ and Q (Gln) ${ }^{9,10}$.

Although the primary sequences of N/OFQ and endogenous opioid peptides exhibit some similarity, N/OFQ binds selectively to the orphanin receptor. It was shown that this high degree of selectivity is caused by nociceptin having a Phe residue at its $\mathrm{N}$-terminus, in contrast to opioid endopeptides, where Tyr is present at this location ${ }^{10}$.

Following the discovery of N/OFQ, the ORL1 receptor was renamed as N/OFQ peptide receptor, or NOP for short, on the advice of IUPHAR ${ }^{11}$.

\section{Similarities and dissimilarities between the NOP receptor and classical opioid receptors}

The NOP receptor belongs to the superfamily of G-protein coupled receptors (GPCRs) and to the family of $\mathrm{Gi} / \mathrm{G}_{\mathrm{o}}$ proteins ${ }^{12}$. Comparing the cDNAs of the NOP receptor, classical opioid receptors and other GPCRs, it is apparent that they contain a number of conserved amino acids and motifs ${ }^{13}$. The TM2, TM3 and TM7 domains of opioid receptors show significant (70\%) conservation ${ }^{14}$. Intracellular loops (ICL) are also greatly homologous, particularly ICL3 (>80\%), which plays a role in $\mathrm{G}$ protein activation. 
Regarding the tertiary structure of the opioid receptors, it has been found that the ligand binding pocket is located within the transmembrane helices in case of all four receptors ${ }^{15-18}$. The message domains of endogenous opioid peptides (YGGF and FGGF) bind to this site ${ }^{18,19}$.

Besides these similarities it is worth to mention that, among the opioid receptors, NOP and KOP contain a large number of acidic residues in their ECL2 domain, in contrast with DOP and MOP receptors. This considerable variation of ECL2 may be responsible for the specificity of the opioid ligands, since only NOP and KOP can bind the positively charged side chains of ligands containing basic amino acids with high affinity ${ }^{13}$. Moreover only the ECL2 of NOP receptor is involved in receptor activation among the four opioid receptors ${ }^{20}$.

\section{The Nociceptin/Orphanin FQ ligand}

\subsection{The N/OFQ precursor molecule}

Human N/OFQ is derived from a 176-amino-acid precursor molecule prepronociceptin (ppN/OFQ or PPNOC) ${ }^{21,22}$. Prepronociceptin has been described as very similar to endogenous opioid peptide precursors (PPENK, PPDYN, and PPOMC), which is not surprising since the four genes have a common evolutionary origin ${ }^{21,22}$. Furthermore, it has been reported that the primary structure of PPNOC also resembles precursors of opioid peptides in that it contains both the amino terminus signal peptide required for secretion, and basic amino acid pairs that may play a role in precursor maturation or transcription regulation ${ }^{23,24}$.

Nociceptin, nociceptin II, and nocistatin are produced from the precursor peptide. Among these products, only nociceptin binds to the NOP receptor ${ }^{21,22}$. Regarding the pharmacological effect of nociceptin II and nocistatin, nociceptin II plays a role in locomotor activity ${ }^{25}$ and causes analgesia both spinally and supraspinally ${ }^{26}$, while interestingly nocistatin appears to be inactive at the NOP receptor ${ }^{27}$ but decreases nociceptin-induced learning- and memory degradation ${ }^{28}$ in the presence of nociceptin, and has showed antinociceptive effects in pain tests ${ }^{27}$.

\subsection{Metabolism of N/OFQ}

Following the release of nociceptin, aminopeptidase (APN), endopeptidase 24.11 and 24.15, and carboxypeptidase B are involved in its degradation. The enzymes and cleavage products are summarized in Table $\mathbf{1}$ below. 
Table 1: N/OFQ amino peptidases and their products.

\begin{tabular}{|l|l|l|}
\hline Peptidases & Products & Status \\
\hline APN & F + GGFTGARKSARKLANQ & inactive \\
\hline \multirow{4}{*}{ EP24.15 } & FGGFTGARKSAR + KLANQ & inactive \\
\cline { 2 - 3 } & FGGFTGARKSA + RKLANQ & inactive \\
\cline { 2 - 3 } & FGGFTGA + RKSARKLANQ & inactive \\
\hline \multirow{2}{*}{ EP24.11 } & FGGFTGARKSARK + LANQ & active \\
\cline { 2 - 3 } & FGGFTGARK + SARK & inactive \\
\hline
\end{tabular}

APN cleaves nociceptin in one step and yields an inactive product. The first product of EP24.11 is N/OFQ(1-13). It is known that N/OFQ(1-13)-OH exhibits weak affinity but is still an active compound ${ }^{29}$. However, by amidation of the C-terminus, higher affinity and activity, comparable to that of the initial nociceptin peptide can be obtained ${ }^{10,30}$. EP24.15 cleaves nociceptin into three inactive products ${ }^{31}$.

\subsection{Message and address domains}

The structures of both opioid peptides and nociceptin can be divided into message and address domains. The message domain, responsible for biological activity, comprises the first four amino acids, while the address domain carries those amino acid residues that play a role in receptor binding ${ }^{32}$.

The ligands bind to each other's receptors with negligible affinity presumably due to the first amino acid at the $\mathrm{N}$-terminus of the peptides, namely Tyr in case of classical opioid ligands and Phe in nociceptin. These may be responsible for the high degree of selectivity of the classical endogenous opioid ligands. Dynorphin A is the most similar to nociceptin, since both peptides consist of 17 amino acids and contain numerous positively charged basic residues in their address domains (Fig. 1) ${ }^{10}$. 


\section{Message domain \\ Address domain \\ Dynorphin A H-Tyr-Gly-Gly-Phe-Leu-Arg-Arg-Ile-Arg-Pro-Lys-Leu-Lys-Trp-Asp-Asn-Gln-OH}

\section{Nociceptin H-Phe-Gly-Gly-Phe-Thr-Gly-Ala-Arg-Lys-Ser-Ala-Arg-Lys-Leu-Ala-Asa-Gln-OH}

Fig. 1: Structural similarities between the nociceptin and dynorphin A amino acid sequences.

\section{Tissue distribution and biological role of the N/OFQ-NOP receptor system}

The NOP receptor and its ligand are present not only in the central nervous system but also in many peripheral organs and even in the immune system.

The N/OFQ-NOP receptor system plays an important role in the cardiovascular and renal system. N/OFQ is involved in the development of bradycardia, hypotension ${ }^{33}$ and diuresis ${ }^{34}$. Moreover, it has been described that it inhibits gastrointestinal and airway motility ${ }^{33,35-38}$. It also behaves as an immunomodulator ${ }^{39}$, thus playing a role in the pathophysiology of sepsis and asthma. In sepsis, the administration of N/OFQ enhanced the inflammatory response ${ }^{33}$ and caused hypotension in septic shock, increasing the mortality rate of rodents ${ }^{40}$. However, the mortality rate could be halved through administration of a NOP receptor antagonist ${ }^{33}$. In mice with the NOP receptor gene knocked out, the inflammatory response was weaker ${ }^{33}$.

The NOP receptor is found in abundant quantities in the forebrain, the midbrain, the dorsal and ventral horns of the spinal cord ${ }^{41,42}$ and the brain stem. NOP receptors are largely observed in pain-related brain regions, both ascending and descending pathways including PAG, the thalamic nuclei, the somatosensory cortex, the rostral ventral medulla, the lateral parabrachial nucleus, the spinal cord and the dorsal root ganglia ${ }^{41,43}$. NOP receptors are also present in significant amounts in regions that mediate reward, namely the mesocorticolimbic reward circuitry including the ventral tegmental area (VTA), the nucleus accumbens, the prefrontal cortex, and in the central amygdala which is associated with stress and plays a role in drug relapse ${ }^{13,41}$. In addition to pain, reward, stress and anxiety, the NOP receptor is involved in many other central processes such as learning and memory, emotional states, neuroendocrine regulation, food intake, and motor control ${ }^{13}$.

The effect of N/OFQ is mainly influenced by two factors: the dose and the route of administration ${ }^{10}$. If N/OFQ is administered i.c.v. to rodents, it induces hyperalgesia and allodynia, and blocks the analgesic effect of MOP, DOP and KOP receptors. NOP receptors in PAG may be responsible for this effect ${ }^{8,9,44}$. In the spinal cord N/OFQ has bidirectional effects, 
since it shows a pronociceptive effect in very low (femtomolar) concentrations, while in higher (nanomolar) dosage it has an analgesic effect ${ }^{45,46}$. It is postulated that achievement of an antinociceptive effect through inhibition of the NOP receptor is only possible using i.c.v. administered NOP receptor antagonists. This proved to be true for peptide antagonists, but the use of small-molecule ligands such as JTC-801 resulted in an observation that antinociceptive effect can be achieved with systematic administration as well ${ }^{13,47-50}$.

It has been found that NOP receptor antagonists administered i.c.v. prior to treatment with systematic morphine inhibited the development of tolerance ${ }^{51-53}$. This is thought to be explained by the N/OFQ-NOP receptor system otherwise becoming upregulated in the brain, which in turn inhibits the analgesic effect of morphine and promotes the development of tolerance. These negative effects can indeed be reduced by NOP receptor antagonists ${ }^{13}$.

Surprisingly, no development of tolerance was observed when N/OFQ itself was given to rodents i.c.v. after daily systematic treatment with morphine ${ }^{54}$. Based on the above seemingly contradictory results, further experiments are needed to clarify the exact role of N/OFQ in opiate tolerance.

When investigating the role of N/OFQ in dependence, it has been found that N/OFQ and other NOP receptor agonists may reduce extracellular dopamine levels in the nucleus accumbens as well as drug-induced dopamine levels ${ }^{13}$. This explains that i.c.v. administration of N/OFQ inhibits cocaine- and alcohol-induced CPP (conditioned place preference) ${ }^{55-59}$. Furthermore, N/OFQ and other NOP receptor agonists reduce the alcohol consumption of rats 60,61 .

In addition, agonists can be used as anxiolytics, antiepileptics and anti-cough agents. They stimulate food intake, spinally reduce pain and drug abuse, and are able to treat hyponatremia and water retention ${ }^{30}$. Antagonists can be used as analgesics, alone or in combination with opiates, but their antidepressant, appetite suppressant and memory enhancing effects should also be recognized. They have been proven to be promising tools in the treatment of Parkinson's disease as well ${ }^{10}$.

\section{Structure-activity relationship studies on N/OFQ}

A large number of structure activity assays were performed on the N/OFQ peptide sequence, including alanine scanning and peptide truncation assays to identify those amino 
acids that play a role in receptor affinity and affect agonist efficacy. The aim of these studies was to develop NOP receptor agonists, partial agonists and antagonists with high affinity and selectivity.

It has been shown that the N-terminal part of N/OFQ is the most sensitive to structural and conformational modifications, in particular the amino acids $\mathrm{Phe}^{1}, \mathrm{Gly}^{2}, \mathrm{Phe}^{4}$ and $\mathrm{Arg}^{8}{ }^{62}$. The Table 2 summarizes the most important amino acid substitutions which affected the affinity or activity of the original N/OFQ. 
Table 2: Amino acid substitutions and their effect on affinity and activity.

\begin{tabular}{|c|c|}
\hline Compound & Effect \\
\hline N/OFQ & original ligand \\
\hline$\left[\mathrm{Tyr}^{1}\right] \mathrm{N} / \mathrm{OFQ}$ & loss of NOP receptor selective affinity ${ }^{32,63}$ \\
\hline$\left[X^{2}\right] \mathrm{N} / \mathrm{OFQ}$ & inactive $^{32}$ \\
\hline$\left[\mathrm{Tyr}^{4}\right] \mathrm{N} / \mathrm{OFQ}$ & retained affinity, loss of activity ${ }^{32,63}$ \\
\hline$\left[\mathrm{Ala}^{5}\right] \mathrm{N} / \mathrm{OFQ}$ & slightly reduced affinity ${ }^{62}$ \\
\hline$\left[\mathrm{Ala}^{6}\right] \mathrm{N} / \mathrm{OFQ}$ & slight loss of activity ${ }^{62}$ \\
\hline$\left[\mathrm{X}^{8}\right] \mathrm{N} / \mathrm{OFQ}$ & inactive $^{64}$ \\
\hline$\left[\mathrm{Ala}^{8}, \mathrm{Ala}^{9}\right] \mathrm{N} / \mathrm{OFQ}$ & significantly reduced affinity and activity ${ }^{32}$ \\
\hline$\left[\mathrm{Y}^{10}\right] \mathrm{N} / \mathrm{OFQ}$ & slightly reduced affinity ${ }^{62}$ \\
\hline$\left[\mathrm{Ala}^{12}, \mathrm{Ala}^{13}\right] \mathrm{N} / \mathrm{OFQ}$ & significantly reduced affinity and activity ${ }^{32}$ \\
\hline$\left[\operatorname{Arg}^{14}, \mathrm{Lys}^{15}\right] \mathrm{N} / \mathrm{OFQ}$ & increased potency $^{62}$ \\
\hline$\left[\operatorname{Trp}^{14}\right.$, Lys $\left.^{15}\right] \mathrm{N} / \mathrm{OFQ}$ & more potent than $\left[\mathrm{Arg}^{14}{ }^{14} \mathrm{Ls}^{15}\right] \mathrm{N} / \mathrm{OFQ}{ }^{62}$ \\
\hline$\left[\operatorname{Trp}^{14}, \mathrm{Arg}^{15}\right] \mathrm{N} / \mathrm{OFQ}$ & more potent than $\left[\mathrm{Arg}^{14}{ }^{14 y s}{ }^{15}\right] \mathrm{N} / \mathrm{OFQ}{ }^{62}$ \\
\hline$\left[\mathrm{Lys}^{14}{ }^{14}\right.$ Lys $\left.^{15}\right] \mathrm{N} / \mathrm{OFQ}$ & superagonistic effect $^{62}$ \\
\hline$\left[\mathrm{Arg}^{14}, \mathrm{Arg}^{15}\right] \mathrm{N} / \mathrm{OFQ}$ & superagonistic effect ${ }^{62}$ \\
\hline$\left[\mathrm{Lys}^{14}, \mathrm{Arg}^{15}\right] \mathrm{N} / \mathrm{OFQ}$ & superagonistic effect ${ }^{62}$ \\
\hline$\left[\mathrm{Lys}^{14}, \mathrm{Trp}^{15}\right] \mathrm{N} / \mathrm{OFQ}$ & slightly increased affinity ${ }^{62}$ \\
\hline$\left[\operatorname{Arg}^{14}, \operatorname{Trp}^{15}\right] \mathrm{N} / \mathrm{OFQ}$ & slightly increased affinity ${ }^{62}$ \\
\hline
\end{tabular}

$X$ : any amino acid

Y: D-Ser, Pro or D-Pro

In addition, replacement of the $\operatorname{Arg}^{8} \operatorname{Lys}^{9}$ and $\operatorname{Arg}^{12} \operatorname{Lys}^{13}$ amino acid pairs with Ala significantly impaired ligand activity and affinity ${ }^{32}$. These positively charged basic residues may presumably interact with the acidic residues in the ECL2 domain of the NOP receptor ${ }^{13}$.

It is also worth mentioning that N/OFQ(1-13) - a truncated form of N/OFQ - remained active after the modification, and displayed the same affinity and activity as N/OFQ following its amidation ${ }^{10}$.

\section{Nociceptin unrelated peptides}

In 1997, Dooley et al. identified 15 peptides having high affinity to the NOP receptor from a combinatorial peptide library containing more than 52 million hexapeptides. Five of these peptides were further investigated: Ac-RYYRWR-NH $\mathrm{N}_{2}$, Ac-RYYRWK-NH $\mathrm{N}_{2}$, AcRYYRIK-NH ${ }_{2}$, Ac-RYYKWK-NH ${ }_{2}$ and Ac-RYYLWR-NH ${ }_{2}{ }^{10,13,65,66}$ The high degree of selectivity and affinity shown by the ligands is very surprising in light of their difference from the nociceptin sequence.

The underlying cause could be the presence of such basic amino acids as Lys or Arg that can be found both in the N/OFQ address domain and in Dooley's hexapeptides ${ }^{66}$. The positively 
charged basic side chains of these amino acids may interact with the acidic clusters in the ECL2 domain of the NOP receptor ${ }^{65}$. Some research teams conducted in silico experiments and concluded that Ac-RYYRIK-NH 2 may interact with NOP receptor sites such as N/OFQ(1-7) or (14-17) ${ }^{67-69}$, which confirms that the positively charged side chains link nociceptin and the hexapeptides together. However, the photoaffinity labelling study of Meunier and Bes performed on Ac-RYYRIK-NH 2 does not give a clear answer as to where exactly is AcRYYRIK- $\mathrm{NH}_{2}$ bound to the NOP receptor, since their results indicate that the binding site of this hexapeptide overlaps only partially with that of nociceptin. ${ }^{70}$.

These ligands were further studied in in vitro G-protein activation, forskolin-stimulated cAMP and electrically stimulated mouse vas deferens (MVD) bioassays to determine whether they can activate the G-protein and, if so, to what extent ${ }^{71}$. A variety of studies have shown that these ligands have partial agonist properties without exception ${ }^{71}$.

The five ligands have also been subjected to structural activity relationship (SAR) tests to find out the role of each residue in binding and ligand activity ${ }^{67}$. So far we know the most about Ac-RYYRWK-NH $\mathrm{NH}_{2}$ and Ac-RYYRIK-NH 2 , which were analysed in the majority of the studies, therefore I chose these ligands for further investigation in my thesis.

Several SAR studies have been performed on Ac-RYYRWK-NH ${ }_{2}{ }^{72-75}$. Regarding the role of the acetyl group on the N-terminus, it was found that its substitution affects both potency and efficacy. Pentanoyl-RYYRWK-NH${ }_{2}$ was a highly potent NOP receptor antagonist, but a weak agonist effect was also noticeable ${ }^{73}$. Ala substitution tests have shown that both Arg are required for this hexapeptide to maintain high binding affinity ${ }^{73}$. In contrast, neither Tyr $^{2}$ nor $\mathrm{Tyr}^{3}$ are essential, but the hydroxyl groups of at least one of the Tyr residues are needed to prevent loss of activity ${ }^{73}$.

When examining the $\operatorname{Trp}^{5}$ amino acid, it was found that if this residue is replaced by different aromatic amino acid residues, a partial agonist similar to the initial peptide can be obtained, whose potency is only slightly different from that of Ac-RYYRWK-NH 2 . Furthermore, it was also found that this residue is only important in binding, and it does not play any role in receptor activation ${ }^{75}$.

By using Ac-RYYRWK-NH 2 and the proprietary structure-induction probe (SIP) technology, Zealand Pharma has developed the NOP receptor partial agonist ZP120 (Ac- 
RYYRWKKKKKKK-NH2), which was patented by Serodus ASA in 2011 in Japan under the name SER100.

Regarding Ac-RYYRWK-NH $\mathrm{NH}_{2}$ and SER100, they behaved as agonists in in vitro forskolin tests, partial agonists in MVD bioassays, and antagonists in the presence of N/OFQ. The two ligands had sodium-potassium-sparing aquaretic and anti-natriuretic activity in vivo, and behaved as mild vasodilators without causing reflex tachycardia. Ac-RYYRWK-NH $\mathrm{NH}_{2}$ and SER100 blocked bradycardia and hypotension through the NOP receptor. This effect lasted longer in case of SER100 ${ }^{76}$. It has been concluded that SER100 may be suitable for treating hyponatremia and hypokalemia ${ }^{62,63}$. Villar et al. showed that SER100 decreased mean arterial blood pressure and heart rate through the NOP receptor ${ }^{78}$. SER100 proved effective in the first clinical phase. SER100 safely and significantly lowered systolic and diastolic blood pressure for a small group of patients with isolated systolic hypertension ${ }^{79}$.

Ac-RYYRIK-NH $\mathrm{N}_{2}$ is also a frequently studied Dooley peptide. Similar to the others, this hexapeptide also behaved as a per se partial agonist in vitro, but inhibited the binding of the ligand to the receptor in the presence of N/OFQ, also in vitro. Surprisingly, apart from its partial agonist and antagonist effects in vitro ${ }^{80}$, it also produced a full agonist effect, when it was examined in locomotor activity studies ${ }^{81}$.

Structural activity studies have shown that three of the six amino acids ( $\operatorname{Arg}^{1}, \mathrm{Tyr}^{2}$ and $\mathrm{Tyr}^{3}$ ) play a key role in affinity ${ }^{67}$. It has been reported that the acyl group on the N-terminus is essential for binding, and, together with the amide group at the $\mathrm{C}$-terminus, it is also responsible for the activity, as if any of them is missing, the ligand will be completely inactive ${ }^{67}$.

Ac-RYYRIK-ol, which is a C-terminally-modified analogue of Ac-RYYRIK-NH $\mathrm{N}_{2}$, has even higher affinity than the original ligand and exhibits a clear antagonistic effect in vitro ${ }^{82,83}$.

Although Ac-RYYRIK-ol behaved as an antagonist in vitro, it showed NOP receptor agonist effect in vivo ${ }^{84}$. Similarly to N/OFQ, it inhibited locomotor activity in mice, showed pronociceptive effect when administered i.c.v., and increased food intake ${ }^{84}$.

Ac-RYYRIK- $\mathrm{NH}_{2}$ was in the focus of interest several times when MOP/NOP and other OP/NOP receptor bivalent ligands were developed. These bivalent ligands were designed to study the heterodimerization of opioid and NOP receptors and to develop new therapeutic agents ${ }^{85-89}$. 


\section{NOP- and opioid receptor dimerization and cross-talk}

Heterodimerization may change receptor-ligand interaction, receptor functional affinity and receptor trafficking, thus affecting the overall pharmacological properties of the two receptors ${ }^{13}$. NOP/MOP receptor heterodimers have been identified in cell cultures and DRG neurons by co-immunoprecipitation ${ }^{90-92}$ and immunofluorescence microscopy ${ }^{92}$.

When NOP, MOP, DOP and KOP receptors were transfected into tsA-201 cells or rat dorsal root ganglia, it was observed that the NOP receptor is frequently co-expressed with KOP, DOP and MOP receptors ${ }^{13}$. NOP/KOP and NOP/DOP receptor heterodimerization is also supported by the fact that when a member of the suspected heterodimer is activated by its selective ligand, this triggers internalization of the other member ${ }^{93}$.

NOP/MOP colocalization can also give rise to heterodimerization and cross-talks between their intracellular signalling. In those cell types where MOP and NOP receptors were present, the administration of a MOP receptor agonist resulted in NOP receptor desensitization. Specific signal cascade components common to the receptors may be responsible for desensitization ${ }^{13}$. Such common components include, for example, kinase isoforms. It has also been reported that nociceptin treatment has an effect on MOP receptor activation and desensitization ${ }^{94,95}$. For example, in the presence of the NOP receptor antagonists, the affinity of MOP receptor agonists increases about 250 -fold ${ }^{90}$.

The duration of treatment also influenced the effect, as shorter nociceptin treatment in $\mathrm{BE}(2)$-c cells increased MOP receptor desensitization ${ }^{94,95}$, while long-term treatment of BE(2)c and SH-SY5Y cells with nociceptin reduced the ability of MOP receptor agonists to inhibit cAMP accumulation ${ }^{96}$.

\section{Bifunctional and bivalent ligands}

Since the discovery of morphine, a number of new opioid receptor drugs have been developed with the aim of eliminating the severe and unpleasant side effects of opioid pharmaceutics ${ }^{97,98}$. Of the opioid receptors, the MOP receptor plays the most important role and new drugs have been developed for this receptor ${ }^{97-100}$. These new ligands have more or less shown the side effects characteristic to morphine in human medicine. Some of these pharmaceuticals and their side effects are summarized in Table 3. 
Table 3: MOP receptor drugs and their common side effects.

\begin{tabular}{|c|c|}
\hline MOPr drugs & Common side effects \\
\hline Codeine & $\begin{array}{l}\text { lightheadedness, dizziness, sedation, shortness of breath, nausea, } \\
\text { vomiting, sweating, constipation } 101\end{array}$ \\
\hline Fentanyl & fever, respiratory depression, nausea, vomiting, diaphoresis ${ }^{102}$ \\
\hline Levorphanol & $\begin{array}{l}\text { nausea, vomiting, altered mood, pruritus, flushing, difficulties in } \\
\text { urination, constipation, biliary spasm } 103\end{array}$ \\
\hline Meperidine & $\begin{array}{l}\text { lightheadedness, dizziness, sedation, nausea, vomiting, sweating } \\
104\end{array}$ \\
\hline Methadone & $\begin{array}{l}\text { euphoria, sedation, respiratory depression, miosis, bradycardia, } \\
\text { physical dependence } 105\end{array}$ \\
\hline Morphine & $\begin{array}{l}\text { drowsiness, dizziness, sedation, fever, anxiety, confusion, tremor, } \\
\text { diaphoresis, lethargy, feeling of warmth, respiratory depression, } \\
\text { dry mouth, constipation, nausea, diarrhea, anorexia, abdominal } \\
\text { pain, vomiting, chest pain, anemia, leukopenia, rash, } \\
\text { peripheral eodema } 106\end{array}$ \\
\hline Oxycodone & $\begin{array}{l}\text { constipation, nausea, somnolence, dizziness, vomiting, pruritus, } \\
\text { headache, dry mouth, asthenia, sweating, nausea, headache, } \\
\text { pyrexia constipation } 107\end{array}$ \\
\hline Oxymorphone & $\begin{array}{l}\text { nausea, pyrexia, somnolence, vomiting, pruritus, headache, } \\
\text { dizziness, constipation, confusion, diarrhea, insomnia, fatigue, } \\
\text { decreased appetite, abdominal pain } 108\end{array}$ \\
\hline Tramadol & $\begin{array}{l}{ }_{109}\end{array}$ \\
\hline
\end{tabular}

Besides ligands acting on one of the receptors, mixed, bivalent and bifunctional opioid ligands were also developed. These ligands target more than one opioid receptors, which hopefully enables them to be more effective and helps reduce their side effects ${ }^{98,100,110}$. Mixed opioid ligands currently on the market show somewhat milder adverse effects, though they are still frequently involved in drug abuse (Table 4). 
Table 4: Mixed Opioid drugs and their side effects.

\begin{tabular}{|c|c|c|}
\hline $\begin{array}{l}\text { Mixed Opioid } \\
\text { Agonist/Antagonist } \\
\text { drugs }\end{array}$ & Receptor Effect & Common side effects \\
\hline Buprenorphine & $\begin{array}{l}\text { partial agonist at } \\
\text { MOPr and NOPr, } \\
\text { antagonist at KOPr } \\
\text { and DOPr } 111-114\end{array}$ & $\begin{array}{l}\text { headache, insomnia, pain, withdrawal, } \\
\text { nausea, constipation, application } \\
\text { site pruritus, vomiting, hyperhidrosis, } \\
\text { dizziness, somnolence, dry mouth, } \\
\text { rash, abuse }{ }^{115,116}\end{array}$ \\
\hline Butorphanol & $\begin{array}{l}\text { antagonist at MOPr, } \\
\text { agonist at } \mathrm{KOPr} 117\end{array}$ & $\begin{array}{l}\text { somnolence, dizziness, nausea, } \\
\text { vomiting, abuse }\end{array}$ \\
\hline Nalbuphine & $\begin{array}{l}\text { antagonist at } \mathrm{MOPr} \\
\text { agonist at } \mathrm{KOPr}\end{array}$ & $\begin{array}{l}\text { sweaty, clammy, nausea, vomiting, } \\
\text { dizziness, vertigo, dry mouth, } \\
\text { headache, abuse }\end{array}$ \\
\hline Pentazocine & $\begin{array}{l}\text { antagonist at } \mathrm{MOPr} \\
\text { agonist at } \mathrm{KOPr}{ }^{123}\end{array}$ & $\begin{array}{l}\text { nausea, dizziness, lightheadedness, } \\
\text { vomiting, euphoria, abuse }\end{array}$ \\
\hline
\end{tabular}

Since the discovery of opioid heterodimers, more and more research groups have dealt with the development of a single ligand targeting multiple opioid receptors. It is widely accepted that multitarget ligands can constitute a much more effective solution for treating certain diseases than drug cocktails. The argument is that these ligands have a better therapeutic effect and can cause fewer side effects despite binding to more than one receptors, since the receptors constitute important therapeutic targets, and the interaction between separate drugs is eliminated ${ }^{126}$.

Potential strategies include targeting receptor dimers with bifunctional or bivalent ligands. Bifunctional and bivalent drugs are not clearly distinguished from each other in the literature, and are sometimes used as synonyms. According to Dietis et al., bifunctional ligands are designed to be non-selective compounds that comprise two protein-binding drug moieties (with or without a spacer) in one chemical structure and act at two different therapeutic targets (Fig. 2) ${ }^{127}$. Bivalent ligands, on the other hand, are intended to be selective compounds, which composed of two distinct pharmacophores joined by a linker and usually have a larger molecular weight than bifunctional ligands (Fig. 2) ${ }^{128}$. They are usually designed to bind to their two targets, which is not always achieved in practice ${ }^{127}$. In the present thesis, the term bifunctional shall be used to refer to our newly synthesized ligands. 


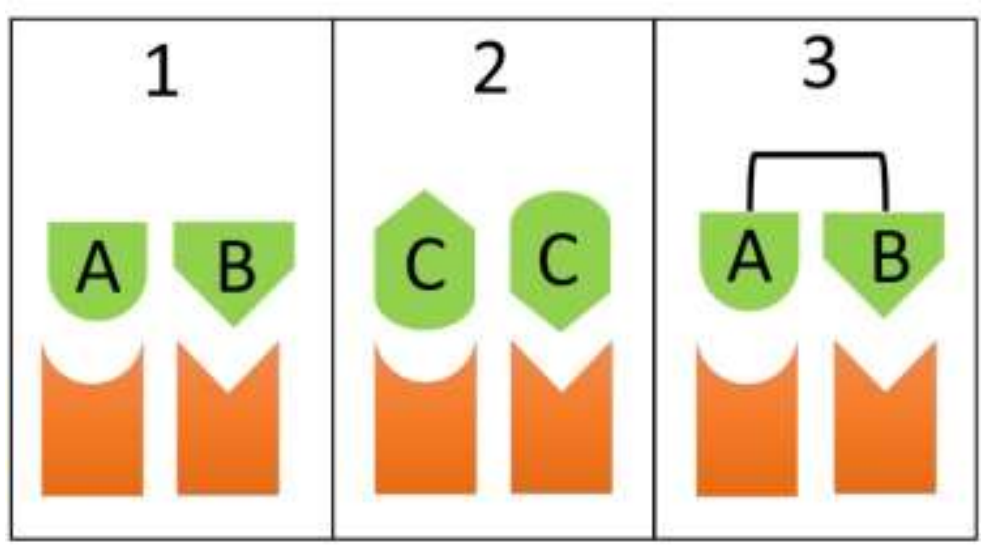

Fig. 2: Three different ways of achieving biological effect through two different receptor targets. Polypharmacy (1) utilizes two distinct ligands, one for each target. Bifunctional (2) and bivalent (3) ligands are compounds that may bind to both receptors, either as a non-selective ligand (2) or two pharmacophores joined to each other (3). Although the receptors are illustrated here as monomers, they might be parts of a dimer that may allow the bivalent ligand to bind to both targets at the same time ${ }^{128}$.

One of the most preferred targets among opioid receptors is the MOP receptor. MOP/DOP ${ }^{129-133}$, MOP/NOP ${ }^{134,135}$, MOP/CCK2 ${ }^{136-138}$, MOP/NK1 ${ }^{137,139,140}$ and MOP/NTS ${ }^{141}$ receptor bivalent ligands have been developed to reduce side effects while maintaining the MOP receptor-mediated analgesic effects.

MOP/DOP ${ }^{129-133}$, MOP/CCK2 ${ }^{136-138}$ and MOP/NK1 ${ }^{137,139,140}$ receptor bivalent ligands were developed using a DOP, CCK2 and NK1 receptor antagonist, respectively, in addition to the MOP receptor agonist, to reduce tolerance and dependence by inhibiting those receptors ${ }^{126}$. Furthermore, MOP/NK1 receptor bivalents also mediated a significant amount of analgesic activity ${ }^{142}$. When MOP/NTS receptor bivalents were synthesized, MOP and NTS receptor agonists were used, since NTS1 and NTS2 are involved in analgesia independently of the opioid system ${ }^{126,141}$.

In addition to these bivalents, MOP/NOP bivalent ligands are also widely researched. NOP receptor agonist and partial agonist ligands are both used for constructing bivalents of the MOP/NOP receptor.

Although not strictly a bivalent ligand, buprenorphine has mixed, non-selective properties (an antagonist of the DOP an KOP receptor, a weak partial agonist of the MOP receptor and a 
very weak partial agonist of the NOP receptor ${ }^{143-146}$ ) and is already widely used in clinical practice $^{147}$. Apart from its analgesic effect, it also reduces opiate and alcohol dependence ${ }^{147,148}$. Among the NOP/MOP receptor agonists, the bifunctional ligand cebranopadol has been found to be effective even in the nanomolar range on the MOP, DOP, KOP and NOP receptors ${ }^{149,150}$. In in vivo tests, it has proved to be an effective substance ${ }^{149,151-153}$. This compound is currently in phase II and III clinical trials ${ }^{150,152}$ investigating the efficacy, safety and tolerability of the orally administered drug. Trials on patients with moderate to severe osteoarthritis are currently in phase IIa ${ }^{152}$. Trials regarding painful diabetic polyneuropathy, diabetic neuropathy or chronic low back pain are in phase II ${ }^{152,154}$, while those concerning severe pain related to cancer are already in phase III ${ }^{152,155,156}$.

Recently Ding et al. have developed AT-121, a bifunctional MOP/NOP agonist, which showed highly potent analgesic effects in nonhuman primates. It had partial agonist activity on both NOP and MOP receptors without inducing the side effects of opioids such as hyperalgesia, respiratory depression, or dependence ${ }^{157}$.

Ac-RYYRIK- $\mathrm{NH}_{2}$ was in the focus of interest several times when MOP/NOP and other OP/NOP receptor bivalent ligands were developed. These bivalent ligands were designed to study the heterodimerization of opioid and NOP receptors, namely, the organization of the heterodimers; to develop new therapeutic agents, and to reduce morphine-related side effects 85-89.

Kawano et al. used dermorphine besides Ac-RYYRIK-NH $\mathrm{NH}_{2}$ to form a MOP receptor agonist and NOP receptor antagonist ligand. Analogue 1, which they have created, binds to the MOP receptor with 200 times higher affinity than the starting ligands, and to the NOP receptor with 17 times higher affinity ${ }^{85}$.

Guillemyn et al. developed an effective MOP agonist and weak NOP antagonist peptide ligand 13a (H-Dmt-D-Arg-Aba- $\beta$-Ala-Arg-Tyr-Tyr-Arg-Ile-Lys- $\mathrm{NH}_{2}{ }^{86}$. Intravenous 13 a has a more prolonged effect than morphine. Intrathecally it had superior anti-allodynic and antihyperalgesic properties than either morphine or Ac-RYYRIK-NH 2 . Overall, this ligand can be already effective at nanomolar concentrations and may be useful for both acute and neuropathic pain ${ }^{86}$.

Similarly to the previous research groups, Lagard et al. also used Ac-RYYRIK-NH 2 to form their MOP/NOP receptor bivalent ligands ${ }^{87}$. After acute and neuropathic pain tests, 
KGNOP1 (H-Dmt-D-Arg-Aba-bAla-Arg-Tyr-Tyr-Arg-Ile-Lys-NH $\mathrm{N}_{2}$ ) proved to be the most promising as its analgesic effect was more effective than that of even tramadol or morphine. In addition, its effect on respiratory depression was minimal ${ }^{87}$. 


\section{AIM OF THE STUDIES}

The N/OFQ-NOP receptor system is widely distributed in both the central and peripheral nervous systems, the airways, the cardiovascular system, the urogenital and gastrointestinal tracts, and the immune system. Since the N/OFQ-NOP receptor system is implicated in the regulation of numerous different biological functions in different ways, both NOP receptor agonists, antagonists and partial agonists are potentially useful tools for treating NOP receptorrelated disorders ${ }^{158}$.

The NOP receptor constitutes heterodimers with MOP, DOP and/or KOP receptors, which allows us to regulate these heterodimers with a single ligand. Thus, such therapeutic agents may be generated that are effective even at low doses without adverse effects.

In the present thesis 12 newly synthesized peptide ligands are described, 9 of which are N/OFQ variants and 3 of which OP/NOP receptor bifunctional ligands. 4 of the N/OFQ variants only contained elements of the N/OFQ sequence, while the remaining 5 also contained parts from the Ac-RYYRIK-NH 2 sequence.

Two of the three bifunctional ligands carry the YGGF tetrapeptide at the N-terminal end and the RYYRIK hexapeptide at the C-terminal end. The third ligand has Ac-RYYRIK at its C-terminus and contains Leu-enkephalin (YGGFL) instead of YGGF. The pharmacophores of the bifunctional ligands are directly linked to one another by a GGG (tri-glycil) spacer. The purpose of this study was the biochemical and pharmacological characterization of these newly synthetized bifunctional analogues and fused nociceptin-RYYRIK hybrid peptides.

The objectives of this study were set out as follows:

- to characterize the binding affinity of 3 bifunctional ligands towards MOP, DOP, KOP and NOP receptors and the 9 fused N/OFQ hybrid peptides towards NOP receptor on rat and guinea pig brain membranes,

- to investigate the opioid receptors mediated G-protein activity in a functional $\left[{ }^{35} \mathrm{~S}\right] \mathrm{GTP} \gamma \mathrm{S}$ binding assay,

- and to investigate the pharmacological activity on isolated MVD (mouse vas deferens), which contains all opioid receptors, including NOP receptor. 


\section{MATERIALS AND METHODS}

\section{Chemicals}

\subsection{Radiochemicals}

$\left[{ }^{3} \mathrm{H}\right]$ Nociceptin (specific activity: $115.5 \mathrm{Ci} / \mathrm{mmol}$ ) and $\left[{ }^{3} \mathrm{H}\right] \mathrm{U}-69,593$ (specific activity: 43.6 Ci/mmol) were purchased from PerkinElmer (Boston, USA). [ $\left.{ }^{3} \mathrm{H}\right] \mathrm{DAMGO}$ (specific activity: $38.8 \mathrm{Ci} / \mathrm{mmol}$ ), [ $\left.{ }^{3} \mathrm{H}\right] \mathrm{IleDelt}$ II (specific activity: 19,6 Ci/mmol) and $\left[{ }^{3} \mathrm{H}\right] \mathrm{HS} 665$ (specific activity: $13.1 \mathrm{Ci} / \mathrm{mmol}$ ) were radiolabeled by the Laboratory of Chemical Biology group in BRC (Szeged, Hungary) and were characterized previously ${ }^{158}$. Guanosine-5 $-\left[{ }^{35} \mathrm{~S}\right]-$ triphosphate (specific activity: $1000 \mathrm{Ci} / \mathrm{mmol}$ ) was purchased from Hartmann Analytic (Braunschweig, Germany).

\subsection{Peptides}

$\left[\mathrm{d}-\mathrm{Ala}^{2}, \mathrm{~d}-\mathrm{Leu}^{5}\right]$ enkephalin (DADLE) was purchased from Sigma-Aldrich (Budapest, Hungary).

H-YGGF-OH (YGGF), Leu-enkephalin (H-YGGFL-OH, YGGFL) and N/OFQ were obtained from Bachem Holding AG (Bubendorf, Switzerland).

Tyr-D-Ala-Gly-(NMe)Phe-Gly-ol (DAMGO) and Ile ${ }^{5,6}$-deltorphin II (IleDelt II) were synthetized in the laboratory of the Chemical Biology Group of the Biological Research Center (BRC, Szeged, Hungary). Ac-RYYRIK-NH 2 , the bifunctional ligands BA55, BA62, BA61 and nociceptin variants P5, P6, P7, P8, P9 were designed by Dr. Sándor Benyhe and synthetized in the laboratory of Dr. Anna Magyar and Dr. Adina Borbély (Research Group of Peptide Chemistry of MTA-ELTE, Budapest, Hungary. P1, P2, P3, P4 were designed by Dr. Ferenc Ötvös and synthetized in the laboratory of Dr. Adriano Mollica (Department of Pharmacy, University of Chieti-Pescara 'G. d'Annunzio', Chieti, Italy). These peptides were synthetized using solid phase peptide synthesis techniques.

The above mentioned 3 bifunctional ligands and the 9 novel nociceptin variants are summarized in Table 5 and Table 6, along with their parent compounds. The nociceptin analogues and nociceptin-RYYRIK hybrid peptides can be sorted into two groups. Group 1 consists of 2 ligands denoted by P2 and P8 (not containing RYYRIK), while Group 2 comprises 7 peptides denoted by P1, P3-7 and P9 (containing RYYRIK). 
Table 5: List of bifunctional ligands (designations and sequences).

\begin{tabular}{cc}
\hline Name (code) & $\begin{array}{c}\text { Sequence } \\
\end{array}$ \\
& $\begin{array}{c}\text { Parent compounds of fused hybrid } \\
\text { peptides }\end{array}$ \\
Dooley's peptide & Ac-RYYRIK-NH 2 \\
Opioid message domain & YGGF \\
& Fused hybrid peptides \\
BA55 & H-YGGFGGGRYYRIK-NH ${ }_{2}$ \\
BA61 & Ac-RYYRIKGGGYGGFL-OH \\
BA62 & H-YGGFRYYRIK-NH $H_{2}$ \\
\hline
\end{tabular}

Table 6: List of fused hybrid peptides and their parent compounds with abbreviated names and sequences.

\begin{tabular}{|c|c|}
\hline Name (code) & Sequence \\
\hline \multirow{4}{*}{$\begin{array}{c}\text { Dooley's peptide } \\
\text { N/OFQ }\end{array}$} & $\begin{array}{l}\text { Parent compounds of fused hybrid } \\
\text { peptides }\end{array}$ \\
\hline & Ac-RYYRIK-NH ${ }_{2}$ \\
\hline & FGGFTGARKSARKLANQ \\
\hline & $\begin{array}{c}\text { Fused hybrid peptides } \\
\text { Group } 1 \text { (without RYYRIK) }\end{array}$ \\
\hline \multirow{3}{*}{$\begin{array}{l}\text { P2 } \\
\text { P8 }\end{array}$} & H-FGGFTSARKGARKLANQ-NH 2 \\
\hline & H-FGGFGGGFGGF-NH 2 \\
\hline & Group 2 (with RYYRIK) \\
\hline $\mathbf{P 1}$ & Ac-RYYRIKGARKLANQ-NH${ }_{2}$ \\
\hline P3 & H-FGGFRYYRIKSARKLANQ-NH ${ }_{2}$ \\
\hline $\mathbf{P 4}$ & Ac-RYYRIKSARKLANQ-NH 2 \\
\hline P5 & Ac-RYYRIKSARKLANQ-OH \\
\hline P6 & Ac-RYYRIKGARKSARKLANQ-OH \\
\hline P7 & Ac-RYYRIKGARKSARK-OH \\
\hline P9 & H-FGGFGGGRYYRIK-NH ${ }_{2}$ \\
\hline
\end{tabular}

Among the 3 bifunctional ligands, BA55 and BA62 contain the YGGF opioid message motif at their N-terminus, while the hexapeptide sequence Ac-RYYRIK- $\mathrm{NH}_{2}$ can be found at the C-terminus. While the constituents of BA62 was connected directly, those of BA55 were interconnected with a triglycine (GGG) spacer. The third chimeric peptide ligand BA61 bears 
the Ac-RYYRIK- $\mathrm{NH}_{2}$ sequence at the N-terminus, which is combined with Leu-enkephalin again via a triglycine spacer.

Group 1 of the nociceptin variants comprises peptides P2 and P8, which contain subsequences of the natural nociceptin peptide only. Group 2 includes those analogues (P1, P3, P4, P5, P6, P7, P9) which were composed of the Ac-RYYRIK- $\mathrm{NH}_{2}$ hexapeptide and parts of the original nociceptin sequence. RYYRIK could be present at the beginning (N-terminal), the middle or the end (C-terminal) of these ligands.

We chose Ac-RYYRIK- $\mathrm{NH}_{2}$ to generate the bifunctional ligands and nociceptin variants because it showed antagonist effects in the presence of N/OFQ and inhibited its biological activity.

\subsection{Other chemicals}

$\mathrm{NaCl}$, EGTA, Tris-HCl (pH 7.4), $\mathrm{MgCl}_{2} \times 6 \mathrm{H}_{2} \mathrm{O}$, GTP analogue GTP $\gamma \mathrm{S}$, Bovine serum albumin (BSA) and KOP receptor specific agonist U-69,593 were purchased from SigmaAldrich (Budapest, Hungary). KOP receptor agonist U50,488H was obtained from the Upjohn Company (Kalamazoo, MI, USA). The NOP receptor antagonist JTC-801 and SB-612111, the KOP receptor antagonist norbinaltorphimine (nor-BNI) and the DOP receptor antagonist naltrindole (NTI) were purchased from Tocris Bioscience (Bristol, UK). KOP receptor agonist Ethylketocyclazocine (EKC) was purchased from Sterling Winthrop (Rensselaer, NY, USA). MOP receptor antagonist cyprodime was a gift from Prof. Helmut Schmidhammer, Innsbruck University, Innsbuck, Austria. The general opioid antagonist naloxone (NX) was kindly provided by the company Endo Laboratories DuPont de Nemours (Wilmington, DE, USA).

The UltimaGold ${ }^{\mathrm{TM}} \mathrm{MV}$ aqueous scintillation cocktail was purchased from PerkinElmer (Boston, USA).

\section{Animals}

Inbred male and female Wistar rats (250-300 g body weight) and male guinea pigs ( $700 \mathrm{~g}$ body weight, LAL/HA/BR strain) were used in all in vitro receptor binding experiments. While guinea pigs were housed in LAB-ÁLL Bt. (Budapest, Hungary), rats were housed in the local animal house of BRC (Szeged, Hungary).

NMRI mice weighing 35-45 g were used throughout in MVD bioassays. Mice were purchased from Toxicoop (Budapest, Hungary) and housed in the local animal house of the 
Department of Pharmacology and Pharmacotherapy, Semmelweis University (Budapest, Hungary).

Animals were kept in groups of five in a temperature controlled room $\left(21-24{ }^{\circ} \mathrm{C}\right)$ under a 12:12 light and dark cycle, and allowed free access to tap water and standard rodent food until the time of sacrifice. The animals were handled humanely, in complete accordance with the European directive 2010/63/EU on the protection of animals used for scientific purposes, the Hungarian Act for the Protection of Animals in Research (XXVIII.tv. 32.§), and the guidelines of the local animal care committee (permit no.: PEI/001/276-4/2013 and 15.1/01882/00051/2009). Both the number of animals and their suffering were minimized throughout our experiments.

\section{Preparation of brain membranes}

Throughout the in vitro receptor binding experiments rat and guinea pig brain membranes were used, which were prepared as previously described ${ }^{159,160}$. Briefly, animals were decapitated and the brains without the cerebellum were quickly removed and washed several times with ice-cold $50 \mathrm{mM}$ Tris-HCl buffer. Then the brains were homogenized in ice-cold buffer using a Braun Teflon-glass homogenizer. The homogenates were filtered through a multilayer gauze filter in order to remove large aggregates and centrifuged at $40,000 \times \mathrm{g}$ for 20 min at $4{ }^{\circ} \mathrm{C}$. The resulting pellet was resuspended in ice-cold $50 \mathrm{mM}$ Tris- $\mathrm{HCl}$ buffer and incubated at $37^{\circ} \mathrm{C}$ for $30 \mathrm{~min}$ in a shaking water-bath ${ }^{161}$.

After incubation the centrifugation was repeated and the final pellet was suspended in 50 $\mathrm{mM}$ Tris- $\mathrm{HCl}$ buffer containing $0.32 \mathrm{M}$ sucrose. The proteins were stored at $-85^{\circ} \mathrm{C}$ until further use.

\section{In vitro biochemical and functional characterization of tested ligands}

\subsection{Competition radioligand binding experiments}

In competition binding experiments, the affinity of an unlabeled compound is analysed by measuring radioligand specific binding in the presence of increasing concentrations of the unlabelled compound in question.

Aliquots of frozen rat and guinea pig brain membrane homogenates were suspended in $50 \mathrm{mM}$ Tris- $\mathrm{HCl}$ buffer with up to $0.3-0.5 \mathrm{mg} / \mathrm{ml}$ of protein. Membranes were incubated with 
increasing concentrations $\left(10^{-10}-10^{-5} \mathrm{M}\right)$ of the unlabelled tested ligands and $1 \mathrm{nM}$ of the radioligands. The latter were applied to measure the ability of competition of the tested ligands towards the opioid receptors. Incubation conditions depended on radioligands: for $\left[{ }^{3} \mathrm{H}\right]$ Nociceptin $30{ }^{\circ} \mathrm{C}$ for $30 \mathrm{~min}$, for $\left[{ }^{3} \mathrm{H}\right] \mathrm{U}-69,59324{ }^{\circ} \mathrm{C}$ for $45 \mathrm{~min}$, for $\left[{ }^{3} \mathrm{H}\right] \mathrm{HS} 66530{ }^{\circ} \mathrm{C}$ for $45 \mathrm{~min}$, and for $\left[{ }^{3} \mathrm{H}\right] \mathrm{DAMGO}$ and $\left[{ }^{3} \mathrm{H}\right] \mathrm{IleDelt} \mathrm{II} 35^{\circ} \mathrm{C}$ for $45 \mathrm{~min}$. As the guinea pig's brain has significantly more KOP receptors than rat brain, we used guinea pig brain as a KOP receptor source in those experiments in which the novel ligands were tested for the KOP receptor ${ }^{162,163}$. In addition, unlabelled nociceptin, U-69,593, IleDelt II, and DAMGO were also incubated together with their labelled counterparts in increasing concentrations $\left(10^{-10}-10^{-5} \mathrm{M}\right)$ as a control.

For experiments performed with $\left[{ }^{3} \mathrm{H}\right]$ Nociceptin, the incubation mixture also contained $0.5 \mathrm{mg} / \mathrm{ml}$ fatty acid-free BSA (pH 7.4).

Non-specific binding was determined in the presence of $10 \mu \mathrm{M}$ unlabelled NX, U-69,593, nociceptin or NTI, while total binding was determined in the absence of the tested compounds. The reaction was terminated by filtrating the samples through Whatman GF/C $\left(\left[{ }^{3} \mathrm{H}\right] \mathrm{DAMGO}\right.$, $\left[{ }^{3} \mathrm{H}\right]$ IleDelt II) or GF/B ([ $\left[{ }^{3} \mathrm{H}\right] \mathrm{U}-69593$ and $\left[{ }^{3} \mathrm{H}\right]$ Nociceptin) glass fibre filters (GE Healthcare, Little Chalfont, UK) under vacuum (Brandel M24R Cell Harvester; Brandel Harvesters, Gaithersburg, MD). Filters were washed three times with $5 \mathrm{ml}$ ice-cold $50 \mathrm{mM}$ Tris-HCl. We used UltimaGold MV aqueous scintillation cocktail (Perkin Elmer, Waltham, MA) with Packard Tricarb 2300TR LSC spectrometer to detect the radioactivity.

The competition binding assays were performed in duplicates and repeated at least three times.

\section{2. $\left[{ }^{35} \mathrm{~S}\right] \mathrm{GTP} \gamma \mathrm{S}$ binding experiments}

The $\left[{ }^{35} \mathrm{~S}\right] \mathrm{GTP} \gamma \mathrm{S}$ binding or GTP exchange assay allows studying $\mathrm{G}$ protein activation (Fig.3). In this assays GDP $\rightarrow$ GTP exchange is measured using non-hydrolysable, radioactive $\left[{ }^{35} \mathrm{~S}\right] \mathrm{GTP} \gamma \mathrm{S}$ in the presence of the tested ligand in a given concentration. G $\alpha$-bound GTP is normally hydrolized by GTPase into GDP+P. On the other hand, $\left[{ }^{35} \mathrm{~S}\right] \mathrm{GTP} \gamma \mathrm{S}$ resists hydrolysis and forms a (radioactive) complex with $\mathrm{G} \alpha$. The measured radioactive signal corresponds to basal activity in the absence of an agonist (Fig. 3). The $\left[{ }^{35} \mathrm{~S}\right] \mathrm{GTP} \gamma \mathrm{S}$ binding experiments also provided opportunity to study antagonism by receptor type-selective ligands. 
Functional $\left[{ }^{35} \mathrm{~S}\right] \mathrm{GTP} \gamma \mathrm{S}$ binding experiments were performed according to previous studies ${ }^{164}$, with slight modifications.

Rat and guinea pig brain membrane fractions $(~ 10 \mu \mathrm{g}$ of protein/sample) were incubated at $30{ }^{\circ} \mathrm{C}$ for $60 \mathrm{~min}$ in Tris-EGTA buffer $(50 \mathrm{mM}$ Tris- $\mathrm{HCl}, 1 \mathrm{mM}$ EGTA, $3 \mathrm{mM} \mathrm{MgCl}$, $100 \mathrm{mM} \mathrm{NaCl}, 30 \mu \mathrm{M}$ GDP, $\mathrm{pH}$ 7.4). The buffer contained $20 \mathrm{MBq} / 0.05 \mathrm{~cm}^{3}$ of $\left[{ }^{35} \mathrm{~S}\right] \mathrm{GTP} \gamma \mathrm{S}$ $(0.05 \mathrm{nM})$ as well as increasing concentrations $\left(10^{-10}-10^{-5} \mathrm{M}\right)$ of the hybrid peptides in the presence or absence of $10 \mu \mathrm{M}$ receptor specific antagonist. The final volume was $1 \mathrm{ml}$.

While total binding was measured in the absence of the tested compounds, non-specific binding (NS) was determined in the presence of $10 \mu \mathrm{M}$ unlabelled GTP $\gamma \mathrm{S}$ and subtracted from the total binding value, to calculate the percentage of the specific binding.

After incubation, the reaction was terminated and bound and unbound $\left[{ }^{35} \mathrm{~S}\right] \mathrm{GTP} \gamma \mathrm{S}$ were separated. The radioactivity of the filters was measured in the same way as described before.

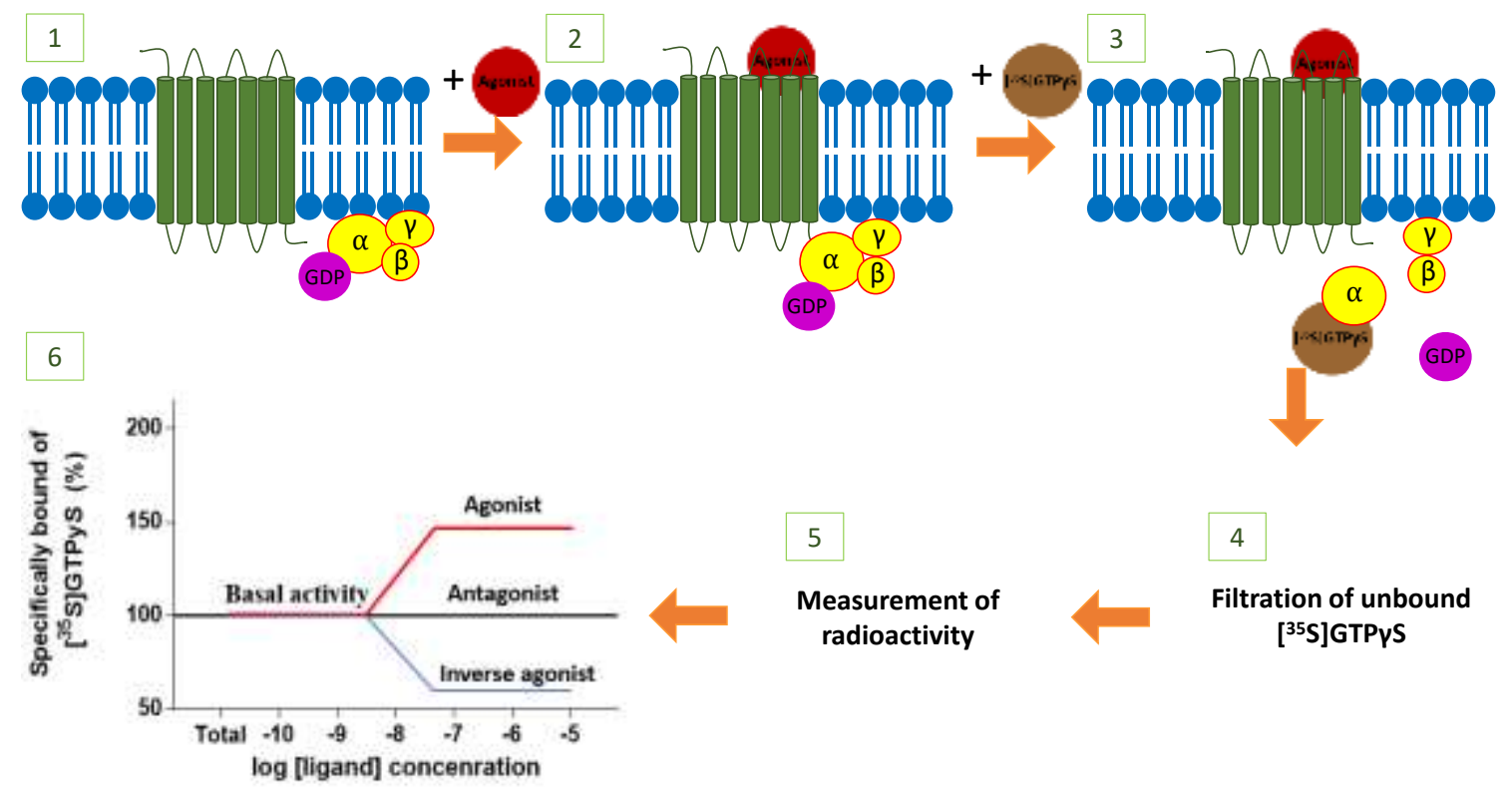

Fig. 3: $\left[{ }^{35} \mathrm{~S}\right] \mathrm{GTP} \gamma \mathrm{S}$ binding experiment. 


\subsection{Isolated mouse vas deferens (MVD) bioassay}

The mouse vas deferens was taken from male mice and prepared to record the isometric smooth muscle contractions.

The preparation was prepared as described previously ${ }^{165}$. Briefly, on the day of the experiment the mice were sacrificed by decapitation and vasa deferentia were removed immediately. Then, the organs were mounted between two electrodes in organ baths of $5 \mathrm{ml}$ volume, containing $\mathrm{Mg}^{2+}$ free Krebs (118.1 mM NaCl, $25 \mathrm{mM} \mathrm{NaHCO}_{3}, 4.7 \mathrm{mM} \mathrm{KCl}, 11 \mathrm{mM}$ glucose, $\left.1.2 \mathrm{mM} \mathrm{KH}_{2} \mathrm{PO}_{4}, 1.8 \mathrm{mM} \mathrm{CaCl}_{2}\right)$ and aerated with carbogen $\left(\mathrm{O}_{2}: \mathrm{CO}_{2}=95: 5\right)$ at $31{ }^{\circ} \mathrm{C}$. The tissues were adjusted to an initial tension of $0.1 \mathrm{~g}$. Stimulation parameters: field stimulation, pairs (100 ms pulse distance) of rectangular impulses (1 ms pulse width, $9 \mathrm{~V} / \mathrm{cm}$ i.e. supramaximal intensity) were repeated by $10 \mathrm{~s}$. The muscle contractions were monitored by computer, using a data recording and analysis system (LabChart 5, ADInstruments Pty LTD, Australia). Before adding the first dose of agonists, 30-40 min equilibration was performed on the tissues. The cumulative concentration-response curves to nociceptin analogues, hybrid peptides and the control compounds were taken.

This bioassay is suitable for assessment of receptors' parameters such as agonist potency and antagonist affinity. These parameters are tools to distinguish between full agonists, partial agonists as well as antagonists ${ }^{166}$.

The affinity of the antagonists is characterized by the equilibrium dissociation constant $\left(\mathrm{K}_{\mathrm{e}}\right)$. To estimate $\mathrm{K}_{\mathrm{e}}$ the 'single-dose' method was applied as described earlier. First, the dose ratio (DR) was calculated based on the degree of change in the potency of agonists in the presence and absence of antagonists as demonstrated in Fig. 4: $D R=C_{3} /\left(C_{2}-C_{1}\right)$. Then $K_{e}$ was calculated according to the following equation: [molar concentration of antagonist]/(DR -1$)$ 167-169. 


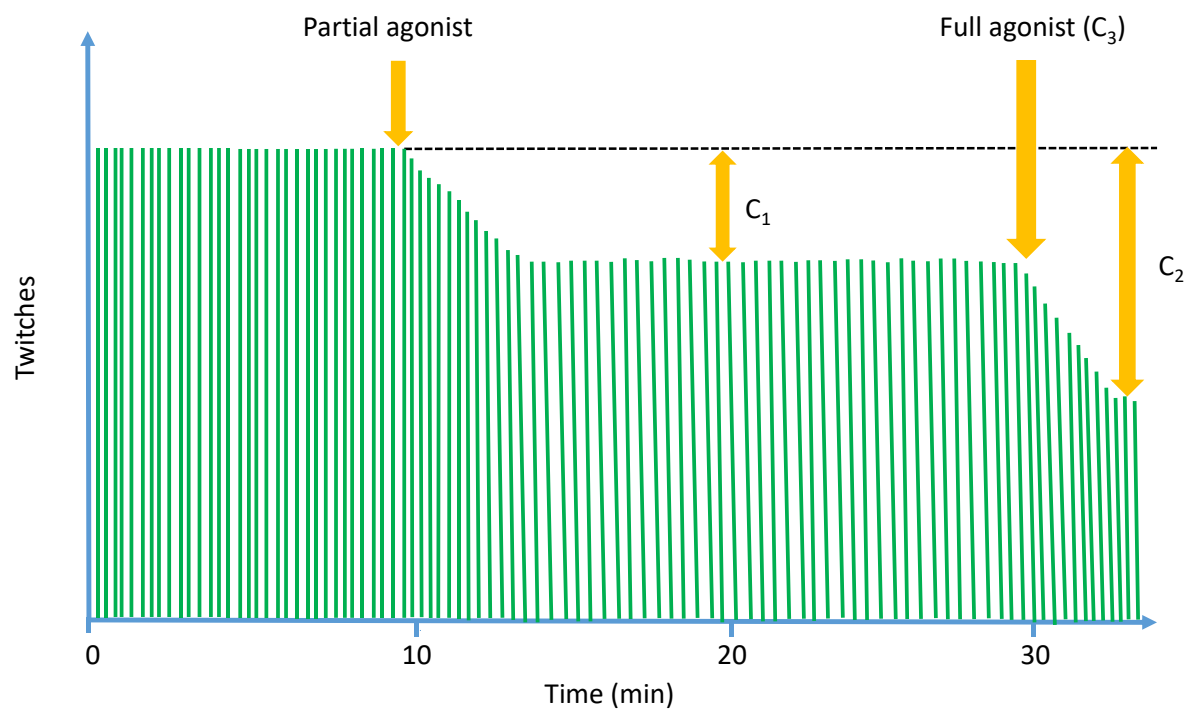

Fig. 4: Determination of the antagonist activity $\left(\mathrm{K}_{\mathrm{e}}\right)$ of a partial agonist with the 'singledose' method. This simplified chart is based on a real isometric recording of contractions of muscle of guinea-pig isolated ileum ${ }^{166-168}$. In this figure, straight lines correspond to the twitch magnitude. Higher lines signify greater longitudinal muscle contraction. (Agonists reduce the extent of contraction.) First the partial agonist is added to the Krebs buffer containing the isolated organ. It reduces muscle contraction by the same amount as the full agonist in $\mathrm{C}_{1}$ concentration. The full agonist is added 20 minutes later in $C_{3}$ concentration, which causes the same reduction in muscle contraction as the $\mathrm{C}_{2}$-concentrated full agonist without the partial agonist ${ }^{166-168}$.

\section{Data analysis}

All the experiments were repeated at least 3 times and the data were expressed as means \pm standard error of mean (S.E.M.) in logarithmic form. The radioligand competition binding experiments were performed in duplicate, while the $\left[{ }^{35} \mathrm{~S}\right] \mathrm{GTP} \gamma \mathrm{S}$ binding assays were carried out in triplicate. The experimental data were analyzed and points were fitted with the professional curve fitting program GraphPad Prism 6.0 (GraphPad Prism Software Inc., San Diego, CA, USA, www.graphpad.com) using non-linear regression. A one-competition-site model was applied in the radioligand competition binding assays to determine unlabelled ligand 
affinity $\left(\mathrm{IC}_{50}\right)$. However, the curves for $\left[{ }^{3} \mathrm{H}\right] \mathrm{DAMGO} / \mathrm{BA} 61$ and $\left[{ }^{3} \mathrm{H}\right] \mathrm{U}-69,593 / \mathrm{BA} 61$ had to be fitted using a 'two-site fit' model yielding higher accuracy.

In the $\left[{ }^{35} \mathrm{~S}\right] \mathrm{GTP} \gamma \mathrm{S}$ binding assays the 'Sigmoid dose-response' equation was used to determine ligand potency $\left(\mathrm{EC}_{50}\right)$ and maximum G-protein efficacy $\left(\mathrm{E}_{\max }\right)$. The curve fitting program output the logarithm of the standard errors of mean for $\mathrm{IC}_{50}$ and $\mathrm{EC}_{50}$ values, due to the data representation.

The equilibrium inhibition constant $\left(\mathrm{K}_{\mathrm{i}}\right)$ was calculated according to the Cheng-Prusoff equation: $\mathrm{K}_{\mathrm{i}}=\mathrm{IC}_{50} /\left(1+[\mathrm{L}] / \mathrm{K}_{\mathrm{d}}\right){ }^{169}$, where $\mathrm{IC}_{50}$ is defined as the concentration of the competitor which produces $50 \%$ displacement, [L] designates the concentration of the labelled ligand and $\mathrm{K}_{\mathrm{d}}$ is the equilibrium dissociation constant.

Binding selectivity ratios were calculated as quotients of the corresponding $\mathrm{K}_{\mathrm{i}}$ values (Table 7). $\mathrm{K}_{\mathrm{i}}$ 's for BA61/ $\left[{ }^{3} \mathrm{H}\right] \mathrm{DAMGO}$ and BA61/[ $\left[{ }^{3} \mathrm{H}\right] \mathrm{U}-69,593$ were calculated using values for the lower affinity sites. Percent relative affinities were quantified according to the formula given by Kosterlitz and Paterson (1980) ${ }^{170}$ :

$$
\frac{\frac{1}{K_{i} \mathrm{MOP}}}{\frac{1}{K_{i} \mathrm{MOP}}+\frac{1}{K_{i} \mathrm{DOP}}+\frac{1}{K_{i} \mathrm{KOP}}+\frac{1}{K_{i} \mathrm{NOP}}} \times 100
$$

To measure basal activity, total binding (T) was measured in the absence of receptor ligands, and non-specific (NS) binding was measured in the presence of $10 \mu \mathrm{M}$ unlabelled GTP $\gamma$ S. The difference between total binding and non-specific binding (T-NS) represented basal activity (100\%). The data were normalized to basal activity.

Agonist potencies were defined as $\mathrm{pEC}_{50}$. It is the negative logarithm with base 10 of the agonist molar concentration that yields $50 \%$ of the maximal possible effect of that agonist.

$\mathrm{E}_{\max }$ is the maximal effect that an agonist can trigger in a given tissue or preparation. In $\left[{ }^{35} \mathrm{~S}\right] \mathrm{GTP} \gamma \mathrm{S}$ binding assays, the $\mathrm{E}_{\max }$ of agonists represents the maximal stimulation over the baseline and it is expressed in \%.

After the analysis of experimental data from the MVD bioassays, $\mathrm{EC}_{50}$ and $\mathrm{E}_{\max }$ were determined from individual logarithmic concentration-response curves. The calculation of equilibrium dissociation constants of the antagonists were described in the previous section. Agonists can be divided into 3 groups based on their sensitivity to NX antagonism. The first 
group comprises MOP receptor agonists which are the most sensitive ${ }^{161,167}$. Here the $\mathrm{K}_{\mathrm{e}}$ value of NX was between 2-3 nM. The second group consists of DOP and KOP agonists, with $\mathrm{K}_{\mathrm{e}}$ values of 20 to $30 \mathrm{nM}{ }^{161,167-169}$. The third group contains those agonists whose effects are mediated by more than one opioid receptors, with intermediate $\mathrm{NX} \mathrm{K}_{\mathrm{e}}$ values in the 3-20 nM range ${ }^{161,167,170}$. Reference ranges for the $K_{e}$ values of naltrindole and nor-BNI on the newly synthetized ligands were $0.057-0.12 \mathrm{nM}$ and $0.26-0.42 \mathrm{nM}$, which were determined using the agonists DADLE and EKC, respectively ${ }^{171,172}$. A two-tailed Welch's t-test was applied for $\mathrm{K}_{\mathrm{e}}$ values regarding the NOP receptor, since no corresponding reference range was available.

Unpaired t-test with Welch's correction was used to see the differences between two data sets, while for three or more data sets one-way ANOVA with Bonferroni's post hoc test was performed to determine statistical significance. Significance was accepted at the $\mathrm{p}<0.05$ level. 


\section{RESULTS}

\section{Competition receptor binding assays}

\subsection{Bifunctional ligands}

Heterologous equilibrium competition curves are shown in Fig. 5, while the analysed data of these assays are summarized in Table 7. Each of the three bifunctional ligand candidate peptides displaced the receptor type-selective radioligands with varying affinities. The highest NOP receptor affinity was obtained with BA61 confirming that the sequence Ac-RYYRIK at the N-terminus carries motifs responsible for NOP receptor interaction. The $\mathrm{K}_{\mathrm{i}}$ values of BA61 were $0.02 \mathrm{nM}$ and $2.4 \mu \mathrm{M}$ measured with $\left[{ }^{3} \mathrm{H}\right] \mathrm{DAMGO}$ and 0.9 and $155 \mathrm{nM}$ measured with $\left[{ }^{3} \mathrm{H}\right] \mathrm{U}-69,593$. These results suggest a biphasic interaction in case of the MOP and KOP receptors. Moreover, the displacement curve of this competition was not complete (Fig. 5, panel C) with substantial residual binding activity (around $50 \%$ ). The apparent high affinities of H-YGGF-OH and BA61 in the KOP receptor assay (Fig. 5, panel C) were also accompanied by higher residual binding levels. 
A

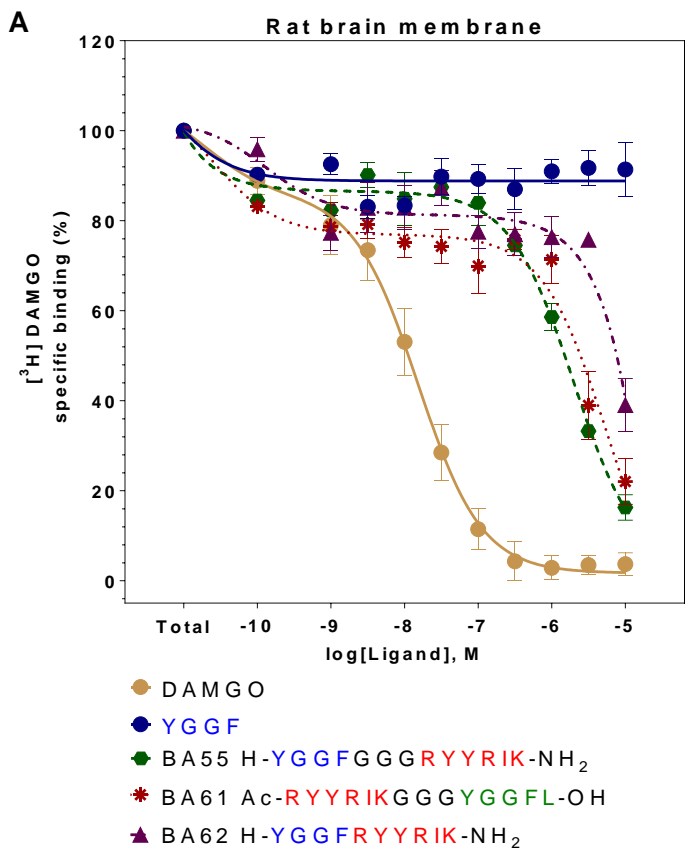

C

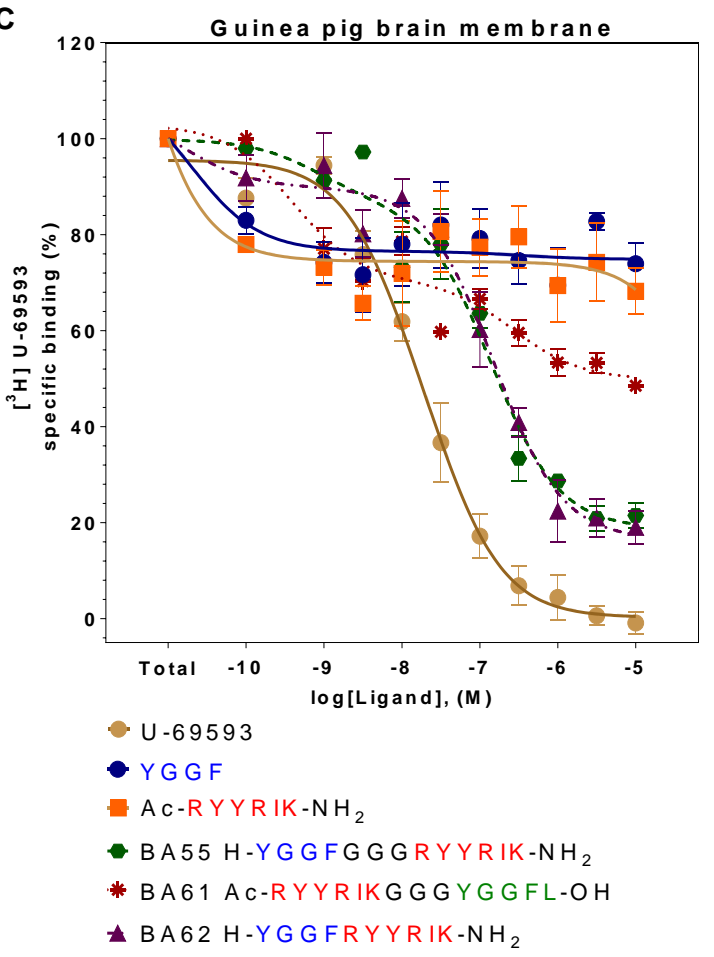

B

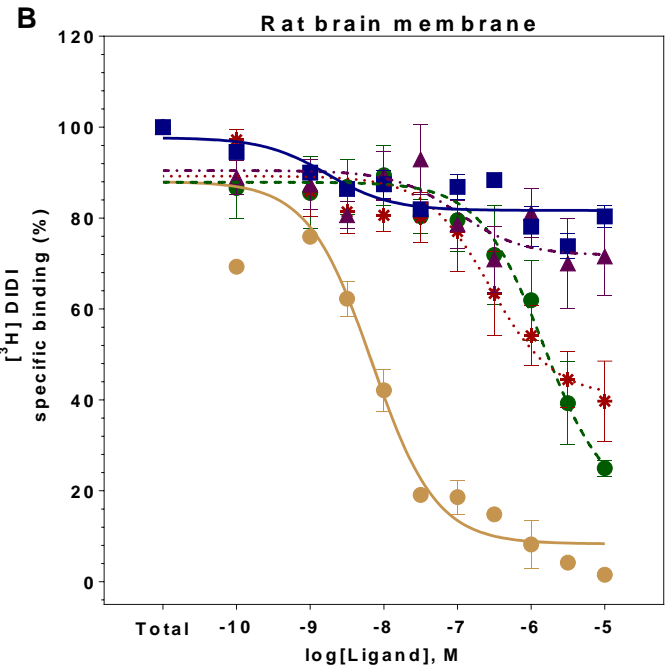

- IleDelt II

- YGGF

- BA 55 H-YGGFGGGYYRIK-NH

* BA61 AC-RYYRIKGGGYGGFL-OH

^BA62 H-YGGFRYYRIK-NH

D

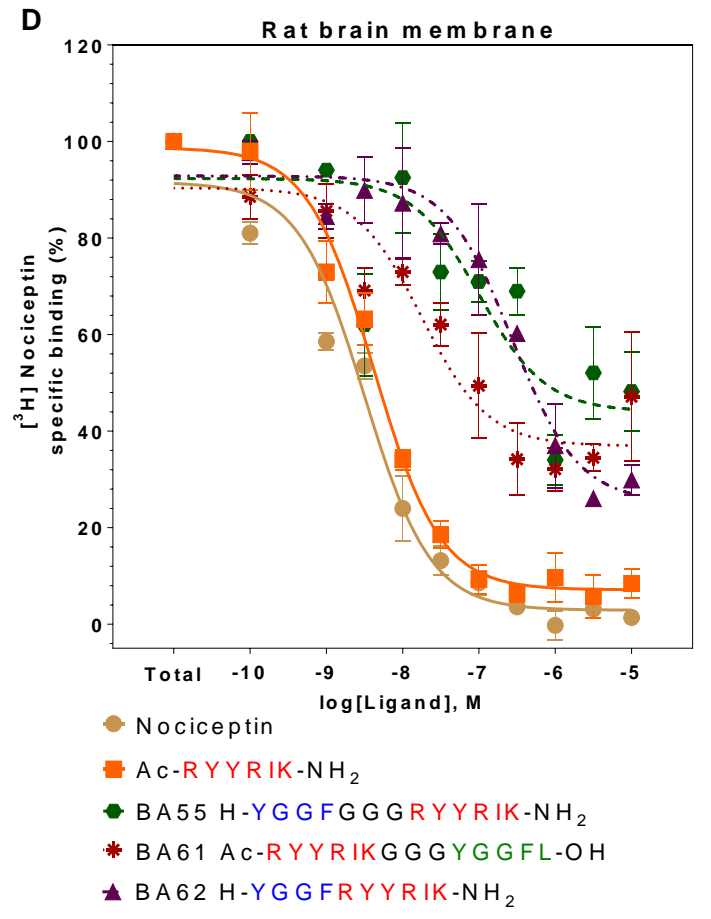

Fig. 5: Displacement of $\left[{ }^{3} \mathrm{H}\right]$ DAMGO, $\left[{ }^{3} \mathrm{H}\right]$ IleDelt II, $\left[{ }^{3} \mathrm{H}\right] \mathrm{U} 69,593$ and $\left[{ }^{3} \mathrm{H}\right]$ Nociceptin radiolabeled ligand by the hybrid peptides and reference ligands. A) MOP receptor, B) DOP receptor, C) KOP receptor, D) NOP receptor assays were done in duplicates and repeated at 
least three times. The equilibrium competition binding experiments were performed in rat (A, $\mathrm{B}$ and D) and in guinea pig (C) brain membrane homogenates.

Based on $\mathrm{K}_{\mathrm{i}}$ values (Table 7) and percent relative affinities (Table 8, last column) BA61 exhibits NOP receptor preference (75\%), while BA62 shows DOP receptor (66\%). BA55 is characterized by high KOP/NOP receptor preference.

Table 7: Evaluation of the three bivalent peptides and the reference compounds in radioligand binding assays.

\section{Affinity, $p \mathrm{IC}_{50} \pm$ S.E.M. $\left(\mathrm{K}_{\mathrm{i}}, \mathrm{nM}\right)$}

\begin{tabular}{|c|c|c|c|c|}
\hline Compounds & $\begin{array}{c}{\left[{ }^{3} \mathrm{H}\right] \mathrm{DAMGO}} \\
\text { (MOPr) }\end{array}$ & $\begin{array}{c}{\left[{ }^{3} \mathbf{H}\right] \text { IleDelt II }} \\
\text { (DOPr) }\end{array}$ & $\begin{array}{c}{\left[{ }^{3} \mathbf{H}\right] \mathrm{U}-69,593} \\
\text { (KOPr) }\end{array}$ & $\begin{array}{c}{\left[{ }^{3} \mathbf{H}\right] \mathbf{N} / \mathbf{O F Q}} \\
\text { (NOPr) }\end{array}$ \\
\hline \multicolumn{5}{|l|}{ Selective agonists: } \\
\hline DAMGO & $\begin{array}{l}7.92 \pm 0.08 \\
(4.15)\end{array}$ & n.d. & n.d & n.d \\
\hline IleDelt II & n.d. & $\begin{array}{c}8.16 \pm 0.12 \\
(1.3)\end{array}$ & n.d & n.d. \\
\hline U-69,593 & n.d. & n.d. & $\begin{array}{c}7.7 \pm 0.07 \\
(11)\end{array}$ & n.d. \\
\hline Nociceptin & $\begin{array}{l}8.26 \pm 0.33 \\
(4.79)\end{array}$ & n.d. & n.d. & $\begin{array}{c}8.5 \pm 0.06 \\
(2.8)\end{array}$ \\
\hline Ac-RYYRIK-NH ${ }_{2}$ & $\begin{array}{c}7.3 \pm 3.2 \\
(24.6)\end{array}$ & - & n.d. & $\begin{array}{c}8.4 \pm 2.52 \\
(4.2)\end{array}$ \\
\hline \multicolumn{5}{|l|}{ Fused hybrid peptides: } \\
\hline $\begin{array}{l}\text { BA55 } \\
\text { H-YGGFGGGRYYRIK- } \\
\mathrm{NH}_{2}\end{array}$ & $\begin{array}{l}5.72 \pm 0.16 \\
\quad(743)\end{array}$ & $\begin{array}{l}5.96 \pm 0.2 \\
\quad(387)\end{array}$ & $6.9 \pm 0.1(58)$ & $\begin{array}{c}6.56 \pm 2.38 \\
(91)\end{array}$ \\
\hline $\begin{array}{l}\text { BA61§ } \\
\text { Ac-RYYRIKGGGYGGFL- } \\
\text { OH }\end{array}$ & $\begin{array}{l}10.6 \pm 0.8 \\
(0.02) \S \\
5.25 \pm 0.2 \\
(2451) \S\end{array}$ & $\begin{array}{c}7.55 \pm 0.27 \\
(73)\end{array}$ & $\begin{array}{l}8.8 \pm 0.2 \\
(0.9) \S \\
6.56 \pm 0.3 \\
(155) \S\end{array}$ & $\begin{array}{c}7.75 \pm 3.32 \\
(16)\end{array}$ \\
\hline $\begin{array}{l}\text { BA62 } \\
\text { H-YGGFRYYRIK-NH }\end{array}$ & $\begin{array}{l}5.24 \pm 0.45 \\
(2530)\end{array}$ & $\begin{array}{l}6.3 \pm 0.35 \\
(28)\end{array}$ & $6.8 \pm 0.1(71)$ & $\begin{array}{l}6.68 \pm 0.26 \\
(244)\end{array}$ \\
\hline
\end{tabular}

n.d.: not determined.

- : no effect

$\S$ Results of two site fit exhibiting high-affinity binding site $\mathrm{K}_{\mathrm{i}}$ value (upper row) and low-affinity binding site $K_{i}$ (lower row) value, respectively. 
Table 8: Receptor-type selectivity comparisons for the hybrid peptides.

\begin{tabular}{|l|c|c|c|c|c|c|c|}
\hline Peptides & \multicolumn{5}{|c|}{ Binding selectivity ratios } & \% relative affinity \\
\hline & $\begin{array}{c}\text { MOPr/ } \\
\text { DOPr }\end{array}$ & $\begin{array}{c}\text { MOPr/ } \\
\text { KOPr }\end{array}$ & $\begin{array}{c}\text { MOPr/ } \\
\text { NOPr }\end{array}$ & $\begin{array}{c}\text { DOPr/ } \\
\text { KOPr }\end{array}$ & $\begin{array}{c}\text { DOPr/ } \\
\text { NOPr }\end{array}$ & $\begin{array}{c}\text { KOPr/ } \\
\text { NOPr }\end{array}$ & MOP:DOP:KOP:NOP \\
\hline BA55 & 1.9 & 13 & 8.2 & 6.7 & 4.3 & 0.6 & $4: 8: 54: 34$ \\
\hline BA61 & 34 & 16 & 153 & 0.5 & 4.6 & 9.7 & $0.5: 16: 8: 75$ \\
\hline BA62 & 90 & 36 & 10 & 0.4 & 0.1 & 0.3 & $1: 66: 26: 8$ \\
\hline
\end{tabular}

\subsection{Nociceptin analogues and nociceptin-RYYRIK hybrid peptides}

As shown in Fig. 6AB and Table 9, peptides P1-P7 competed more effectively for the NOP receptor than $\mathrm{P} 8$ or $\mathrm{P} 9$, which showed negligible affinity.

Among the ligands P1-P7, P3 showed weaker affinity than expected. While P5 yielded a Ki value similar to Ac-RYYRIK- $\mathrm{NH}_{2}$, the Ki value of $\mathrm{P} 1$ was similar to N/OFQ.

P2, P4 and P7 displayed higher affinity to the NOP receptor compared to the parent compounds. Among all nociceptin variants, P6 showed the highest affinity.

Those chimeric peptides which possess Ac-RYYRIK at the N-terminal end were tested for KOP, MOP and DOP receptors, since we wanted to examine their NOP receptor selectivity.

The results showed that no nociceptin-RYYRIK hybrid peptides reduced the specific binding of $\left[{ }^{3} \mathrm{H}\right]$ IleDelt II (data not shown). However, when investigating the direct binding affinity of nociceptin analogues and nociceptin-RYYRIK hybrid peptides towards MOP receptor, [ $\left.{ }^{3} \mathrm{H}\right]$ DAMGO was almost fully displaced from its receptor by $\mathrm{P} 4$ in higher concentrations. P1 and P7 indicated high affinities in the MOP receptor assay, which were also accompanied by higher residual binding levels. (Data not shown.) 
A

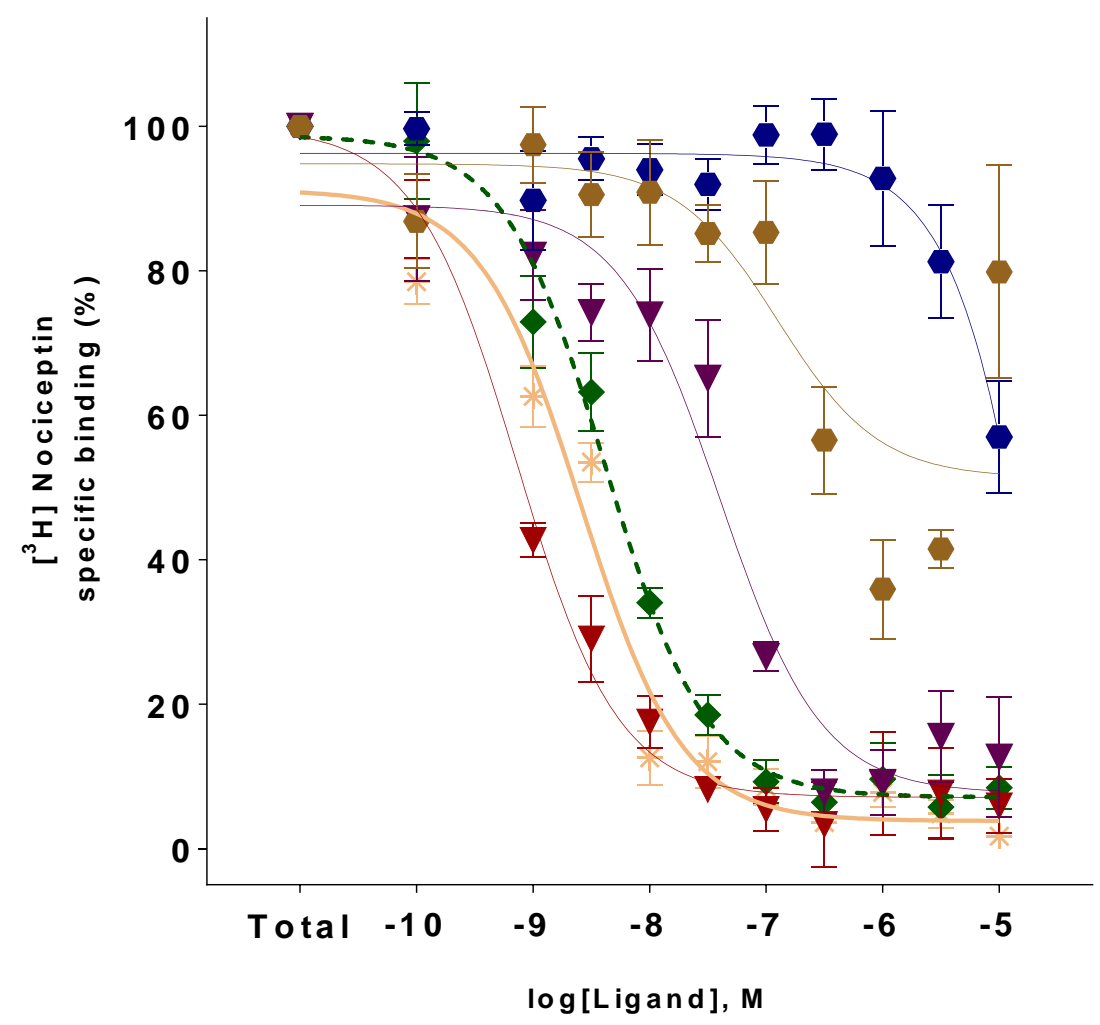

* H-FGGFTGARKSARKLANQ-OH (N/OFQ)

$\checkmark A C-R Y Y R I K-\mathrm{NH}_{2}$

V P2 H-FGGFTSARKGARKLANQ-NH 2

V P3 H-FGGFRYYRIKSARKLANQ-NH ${ }_{2}$

- P8 H-FGGFGGFGGF-NH 2

- P9H-FGGFGGRYYRIK-NH 2 


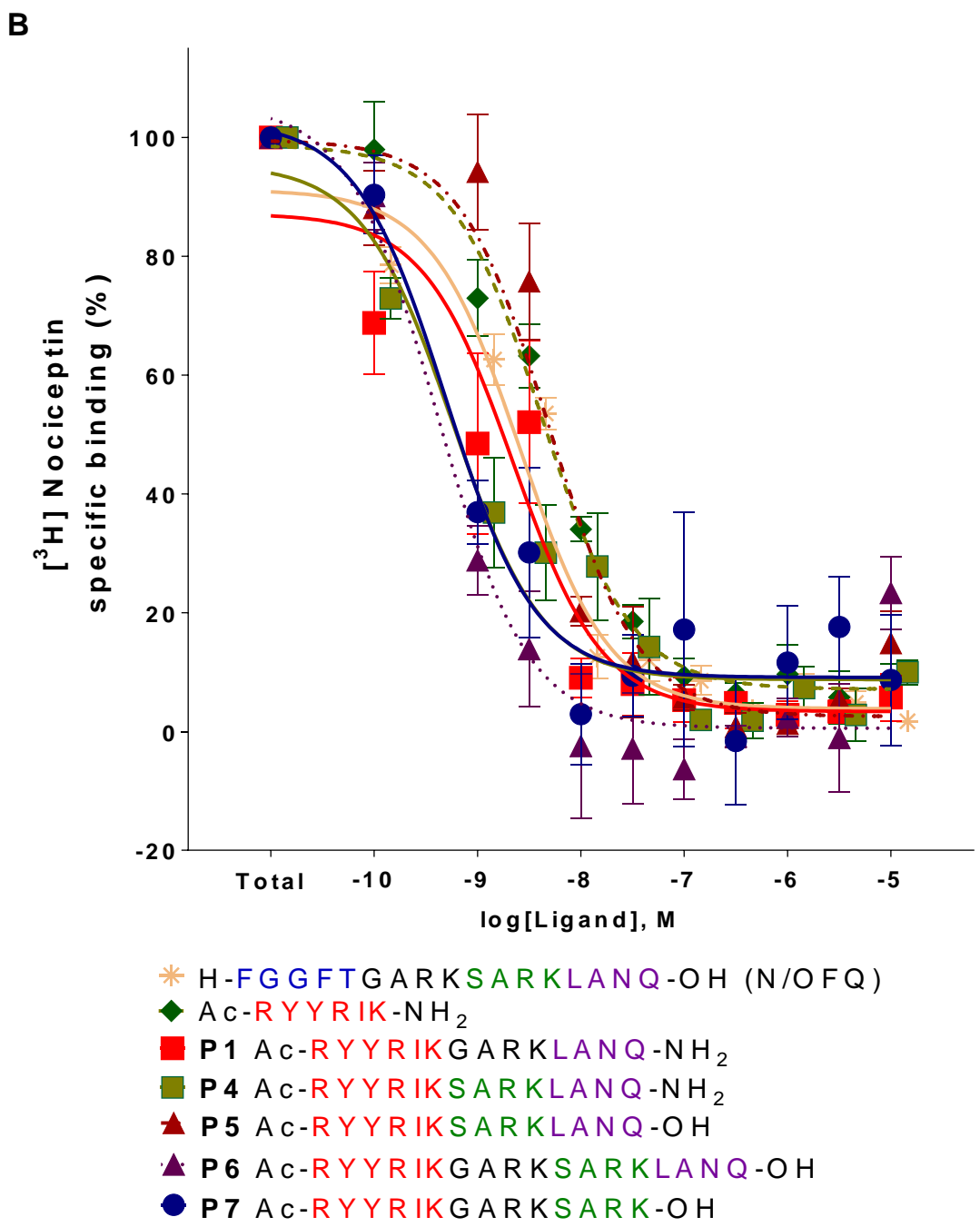

Fig. 6: NOP receptor binding affinity of nociceptin hybrid peptides (A and B) compared to nociceptin and Ac-RYYRIK- $\mathrm{NH}_{2}$ in $\left[{ }^{3} \mathrm{H}\right]$ Nociceptin competition binding assays in rat brain membrane homogenates. Figures represent the specific binding of $\left[{ }^{3} \mathrm{H}\right]$ Nociceptin in percentage in the presence of increasing concentrations $\left(10^{-10}-10^{-5} \mathrm{M}\right)$ of the indicated unlabelled ligands. Points represent means \pm S.E.M. for at least three experiments performed in duplicate. 
Table 9: Competition binding data of nociceptin hybrid peptides and their parent compounds in $\left[{ }^{3} \mathrm{H}\right] \mathrm{DAMGO},\left[{ }^{3} \mathrm{H}\right] \mathrm{HS} 665$ and $\left[{ }^{3} \mathrm{H}\right]$ Nociceptin displacement binding assays. The brain membrane homogenates are from rats and guinea pigs. The $\log \mathrm{IC}_{50}$ values were calculated according to the competition binding curves (see Fig. 6A and B).

\begin{tabular}{|c|c|c|c|c|}
\hline \multirow{2}{*}{\multicolumn{2}{|c|}{ Compounds }} & \multicolumn{3}{|c|}{ Affinity, pIC ${ }_{50} \pm$ S.E.M. $\left(K_{i}, n M\right)$} \\
\hline & & $\begin{array}{c}{\left[{ }^{3} \mathrm{H}\right] \mathrm{HS665}} \\
(\mathrm{KOPr})\end{array}$ & $\begin{array}{c}{\left[{ }^{3} \mathrm{H}\right] \mathrm{DAMGO}} \\
\text { (MOPr) }\end{array}$ & $\begin{array}{c}{\left[{ }^{3} \mathrm{H}\right] \text { Nociceptin }} \\
\text { (NOPr) }\end{array}$ \\
\hline \multicolumn{5}{|c|}{ Parent compounds } \\
\hline & Nociceptin & $* 9.34 \pm 2.9(0.4)$ & $\begin{array}{c}8.26 \pm 0.33 \\
\quad(4.79)\end{array}$ & $8.5 \pm 0.1(2.8)$ \\
\hline & Ac-RYYRIK-NH ${ }_{2}$ & $* 6.22 \pm 1.1(529)$ & $7.3 \pm 3.2(24.6)$ & $8.4 \pm 2.5(4.2)$ \\
\hline \multicolumn{5}{|c|}{ Fused hybrid peptides } \\
\hline P1 & Ac-RYYRIKGARKLANQ-NH ${ }_{2}$ & $* 5.8 \pm 0.5(1287)$ & $7.6 \pm 2.2(13)$ & $8.7 \pm 0.2(2)$ \\
\hline $\mathbf{P 2}$ & H-FGGFTSARKGARKLANQ-NH ${ }_{2}$ & n.d. & n.d. & $9.1 \pm 0.1(0.65)$ \\
\hline P3 & H-FGGFRYYRIKSARKLANQ-NH & n.d. & n.d. & $7.4 \pm 0.12(36)$ \\
\hline P4 & Ac-RYYRIKSARKLANQ-NH ${ }_{2}$ & $* 5.6 \pm 0.2(2179)$ & $5.3 \pm 0.4(2252)$ & $9.3 \pm 0.1(0.6)$ \\
\hline P5 & Ac-RYYRIKSARKLANQ-OH & $* 5 \pm 0.7(8422)$ & $5.6 \pm 3.2(1204)$ & $8.3 \pm 0.1(4.44)$ \\
\hline P6 & $\begin{array}{l}\text { Ac-RYYRIKGARKSARKLANQ- } \\
\mathrm{OH}\end{array}$ & $* 5.5 \pm 0.2(2780)$ & $4.9 \pm 0.7(5994)$ & $9.4 \pm 0.2(0.37)$ \\
\hline P7 & Ac-RYYRIKGARKSARK-OH & $* 8.4 \pm 0.3(3472)$ & $6.4 \pm 0.4(209)$ & $9.3 \pm 0.2(0.44)$ \\
\hline $\mathbf{P 8}$ & H-FGGFGGGFGGF-NH ${ }_{2}$ & n.d. & n.d. & $4.2 \pm 2.2(6192)$ \\
\hline P9 & H-FGGFGGGRYYRIK-NH ${ }_{2}$ & n.d. & n.d. & $6.9 \pm 0.3(112)$ \\
\hline
\end{tabular}

n.d.: not determined.

*: KOP-related experiments were performed on guinea pig brain membranes. 


\section{2. $\left[{ }^{35} \mathrm{~S}\right] \mathrm{GTP} \gamma \mathrm{S}$ binding experiments}

\subsection{Bifunctional ligands}

A

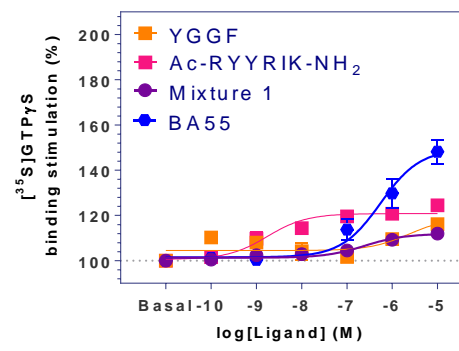

D

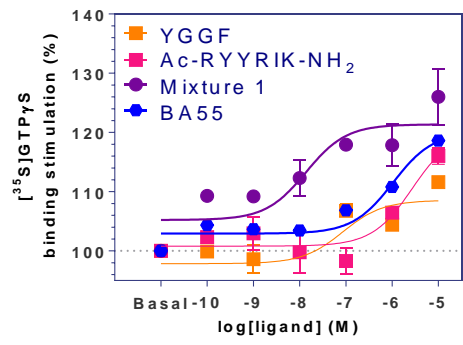

Rat brain membranes

B

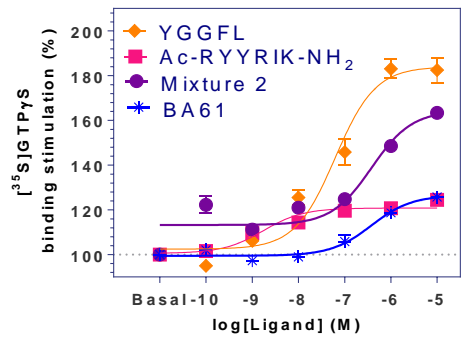

Guinea pig brain membranes

E

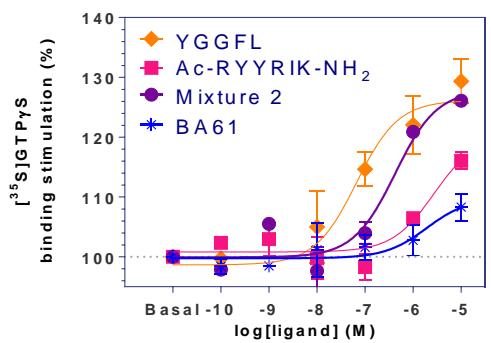

C

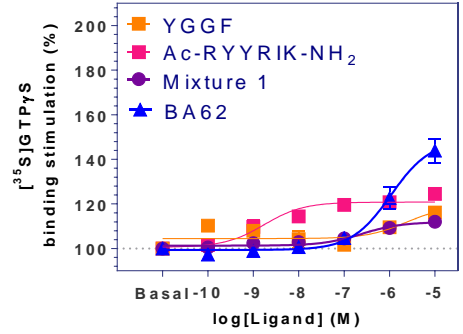

$\mathbf{F}$

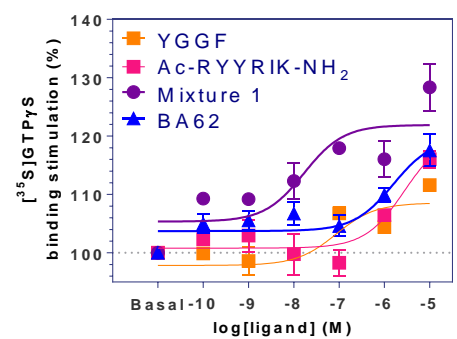

Fig. 7: Peptide agonist induced activation of G-proteins in rat brain (A-C) and in guinea pig brain (D-F) membranes. Points represent means \pm S.E.M. for at least three experiments performed in triplicate. (For some points, the differences between the measurements are negligible, which causes the standard deviation bars to vanish.) 'Mixture' means that the opioid receptor targeting YGGF or YGGFL and the NOP receptor targeting Ac-RYYRIK-NH 2 peptide fragments were concurrently present in the reaction tubes without chemical cross-linking.

All three bifunctional peptide ligands effectively stimulated the activity of regulatory Gproteins in rat brain membranes with maximal stimulation levels of 149:126:149 \% for BA55:BA61:BA62, respectively (Fig. 7 and Table 10). On the basis of these $E_{\max }$ values and those of Leu-enkephalin, BA55 and BA62 are full agonists, while peptide BA61 seems to be a partial agonist. In guinea pig brain membrane fractions the stimulation order was BA55 $\approx$ BA62 $>$ BA61, indicating again the partial agonist nature of BA61 (Fig.7, Panel D and E and F). The effects of the three hybrid peptides were also compared with those of the simple mixtures of their peptide building components (Fig. 7). Curves for the mixtures were substantially 
different from the curves depicting the real hybrid compounds (see Table $\mathbf{1 0}$ for significant differences).

Table 10: Summarized data of G-protein activation by the three chimeric peptides and their parent peptide sequences.

\begin{tabular}{|l|c|c|c|c|}
\hline \multirow{2}{*}{ Peptides } & \multicolumn{2}{|c|}{ Rat brain membranes } & \multicolumn{2}{c|}{ Guinea pig brain membranes } \\
\cline { 2 - 5 } & $\begin{array}{c}\text { Potency, } \\
\mathrm{pEC}_{50} \pm \text { S.E.M. } \\
\left(\mathrm{EC}_{50}, \mathrm{nM}\right)\end{array}$ & $\begin{array}{c}\text { Efficacy, } \\
\% \text { Emax } \\
\pm \text { S.E.M. }\end{array}$ & $\begin{array}{c}\text { Potency, } \\
\mathrm{pEC}_{50} \pm \text { S.E.M. } \\
\left(\mathrm{EC}_{50}, \mathrm{nM}\right)\end{array}$ & $\begin{array}{c}\text { Efficacy, } \\
\text { Emax } \pm \text { S.E.M }\end{array}$ \\
\hline Ac-RYYRIK-NH 2 & $8.76 \pm 0.21(2)$ & $121 \pm 1$ & $5.57 \pm 0.35(2723)$ & $120 \pm 5$ \\
\hline H-YGGF-OH & $5.63 \pm 0.59(2342)$ & $119 \pm 6$ & $7.07 \pm 0.48(85)$ & $108 \pm 3$ \\
\hline Mixture 1 $\S$ & $6.61 \pm 0.37(247)$ & $112 \pm 2$ & $7.86 \pm 2.03(14)$ & $121 \pm 1$ \\
\hline Leu-enkephalin & $7.21 \pm 0.11(62)$ & $184 \pm 4$ & $7.18 \pm 0.27(67)$ & $126 \pm 3$ \\
\hline Mixture 2† & $6.42 \pm 0.14(381)$ & $164 \pm 3 * * *$ & $\begin{array}{c}6.37 \pm 0.18 \\
(424)\end{array}$ & $128 \pm 2$ \\
\hline BA55 & $6.26 \pm 0.18(388)$ & $149 \pm 5$ & $\begin{array}{c}5.98 \pm 0.11 \\
(1039)\end{array}$ & $120 \pm 1$ \\
\hline BA61 & $6.42 \pm 0.15(430)$ & $126 \pm 2$ & $\begin{array}{c}5.72 \pm 0.60 \\
(1929)\end{array}$ & $110 \pm 4$ \\
& & & $5.81 \pm 0.32$ & $120 \pm 3$ \\
\hline BA62 & $5.97 \pm 0.15(442)$ & $149 \pm 4$ & $(1560)$ & \\
\hline
\end{tabular}

$\S$ Mixture 1: Ac-RYYRIK-NH $2+\mathrm{H}-\mathrm{YGGF}-\mathrm{OH}$, without chemical cross-linking of the components

† Mixture 2: Ac-RYYRIK-NH $2+\mathrm{H}-$ YGGFL-OH, without chemical cross-linking of the components

*** Significantly different from Ac-RYYRIK-NH $2(\mathrm{p}<0.001)$ one-was ANOVA followed by Bonferroni's post hoc test.

The stimulating effect of BA55 was significantly antagonised by NTI, nor-BNI, but not by cyprodime. G-protein activation by BA61 was substantially inhibited by JTC-801 and NTI ( $p<0.001)$ and cyprodime $(\mathrm{p}<0.01)$, while not by nor-BNI $($ Fig. 8). The activating effect of the third hybrid peptide (BA62) was effectively antagonised by the JTC-801, NTI and nor-BNI, but, similarly to BA55, it was not inhibited by cyprodime (Fig. 8). 

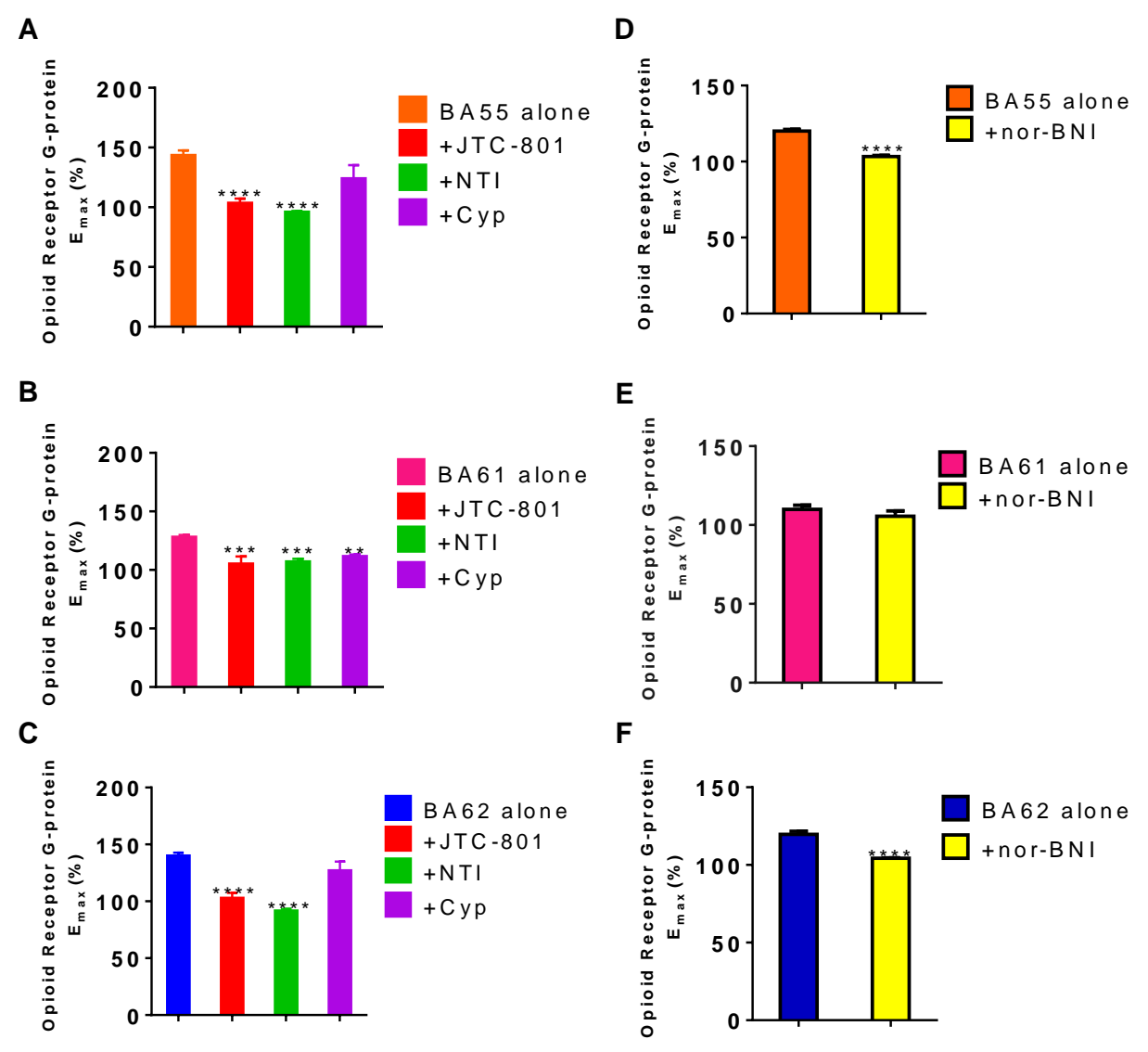

Fig. 8: Effects of opioid family receptor-type specific antagonist ligands on the G-protein activation by the hybrid peptides. Maximal stimulation $\left(\mathrm{E}_{\max }\right)$ values were determined by analysing full dose-response curves. Columns shown represents mean values \pm S.E.M. All antagonists were used in $10 \mu \mathrm{M}$ concentration. (A-C) Rat brain studies with selective antagonists for two classical opioid receptors. **: $\mathrm{p}<0.01$ and $* * *$ : $\mathrm{p}<0.001$, and $* * * *$ : $\mathrm{p}<$ 0.0001 vs. control group (one-way ANOVA followed by Bonferroni's multiple comparison post hoc test). (D-F) Experiments on the KOP receptor of guinea pig brain membranes using nBNI. ****: $\mathrm{p}<0.0001$ vs. control group (unpaired t-test with Welch's correction, two-tailed p-value).

\subsection{Nociceptin analogues and nociceptin-RYYRIK hybrid peptides}

As can be observed in Fig. 9 and Table 11, the $\mathrm{E}_{\max }$ of the NOP receptor during testing the stimulation for all the peptides was moderate except for P2 and P3. While P1, P4-P9 
indicated partial agonist properties, $\mathrm{P} 2$ and P3 exhibited full agonist activities similar to nociceptin.

A

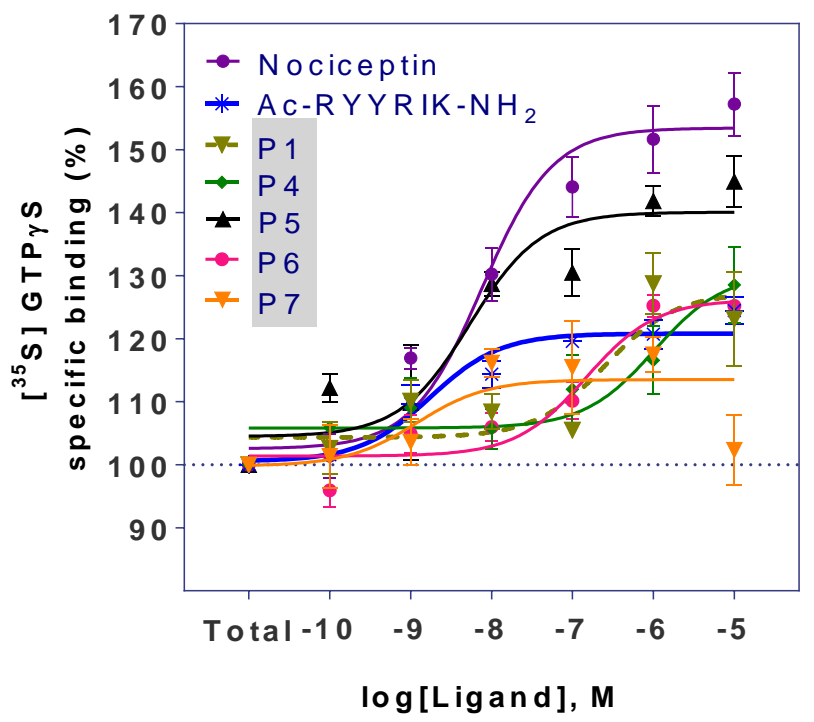

B

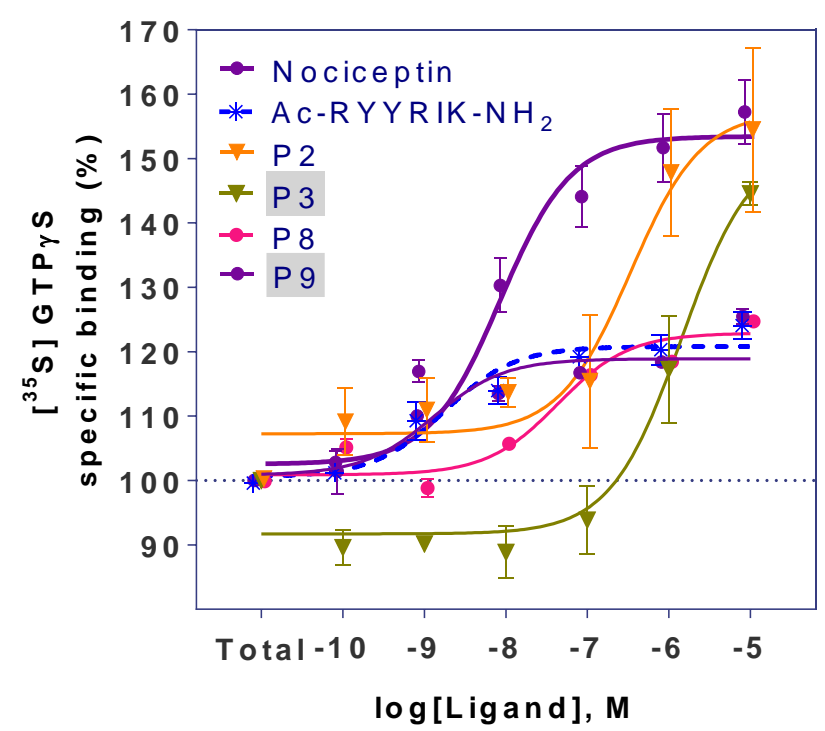

Fig. 9: $\left[{ }^{35} \mathrm{~S}\right] \mathrm{GTP} \gamma \mathrm{S}$ binding experiments. Panel A and B: stimulation of G-protein activation by nociceptin analogues and nociceptin-RYYRIK hybrid peptides (highlighted in grey) induced activation of G-proteins. The experiments were carried out in rat brain membranes. Points represent means \pm S.E.M. for at least three experiments performed in triplicate. 
Table 11: The stimulation of G-protein by the nociceptin hybrid peptides and their parent compounds in $\left[{ }^{35} \mathrm{~S}\right] \mathrm{GTP} \gamma \mathrm{S}$ binding assays using rat brain membrane homogenates. The efficacy $\left(\mathrm{E}_{\max }\right)$ and ligand potency $\left(\mathrm{pEC}_{50}\right)$ values were calculated according to dose-response binding curves.

\begin{tabular}{|c|c|c|c|}
\hline \multicolumn{2}{|c|}{ Peptides } & \multicolumn{2}{|c|}{ Rat brain membranes } \\
\hline & & Potency & Efficacy \\
\hline \multirow{2}{*}{\multicolumn{4}{|c|}{ Parent compounds }} \\
\hline & & & \\
\hline \multicolumn{2}{|c|}{ Nociceptin } & $8 \pm 0.2(7.6)$ & $153 \pm 2.7$ \\
\hline \multicolumn{2}{|c|}{ Ac-RYYRIK-NH ${ }_{2}$} & $8.76 \pm 0.2(2)$ & $121 \pm 1.2$ \\
\hline \multicolumn{4}{|c|}{ Fused hybrid peptides } \\
\hline $\mathbf{P 1}$ & Ac-RYYRIKGARKLANQ-NH ${ }_{2}$ & $6.6 \pm 0.5(258)$ & $127 \pm 4.6$ \\
\hline $\mathbf{P 2}$ & H-FGGFTSARKGARKLANQ-NH ${ }_{2}$ & $6.5 \pm 0.35(338)$ & $157 \pm 0.34$ \\
\hline P3 & H-FGGFRYYRIKSARKLANQ-NH & $6 \pm 0.28(1430)$ & $152 \pm 0.28$ \\
\hline $\mathbf{P 4}$ & Ac-RYYRIKSARKLANQ-NH ${ }_{2}$ & $6 \pm 0.41(1028)$ & $131 \pm 0.42$ \\
\hline P5 & Ac-RYYRIKSARKLANQ-OH & $8.3 \pm 0.3(5.4)$ & $140 \pm 2.6$ \\
\hline P6 & Ac-RYYRIKGARKSARKLANQ-OH & $7.5 \pm 0.6(147)$ & $126 \pm 2.33$ \\
\hline P7 & Ac-RYYRIKGARKSARK-OH & $8.93 \pm 0.51(1.2)$ & $114 \pm 2.5$ \\
\hline P8 & H-FGGFGGGFGGF-NH ${ }_{2}$ & $7.4 \pm 1.2(44)$ & $123 \pm 1.02$ \\
\hline P9 & H-FGGFGGGRYYRIK-NH ${ }_{2}$ & $8.9 \pm 1.3(1.3)$ & $119 \pm 1.01$ \\
\hline
\end{tabular}

Trying to revert or inhibit the G-protein stimulation effect of the tested compounds, we applied SB-612.111 in $10 \mu \mathrm{M}$ concentrations (Fig. 10). The stimulating effects of P2, P3 and P5 were significantly antagonised by SB-612.111, which confirms that the NOP receptor is involved in mediating the effects of these peptides. 


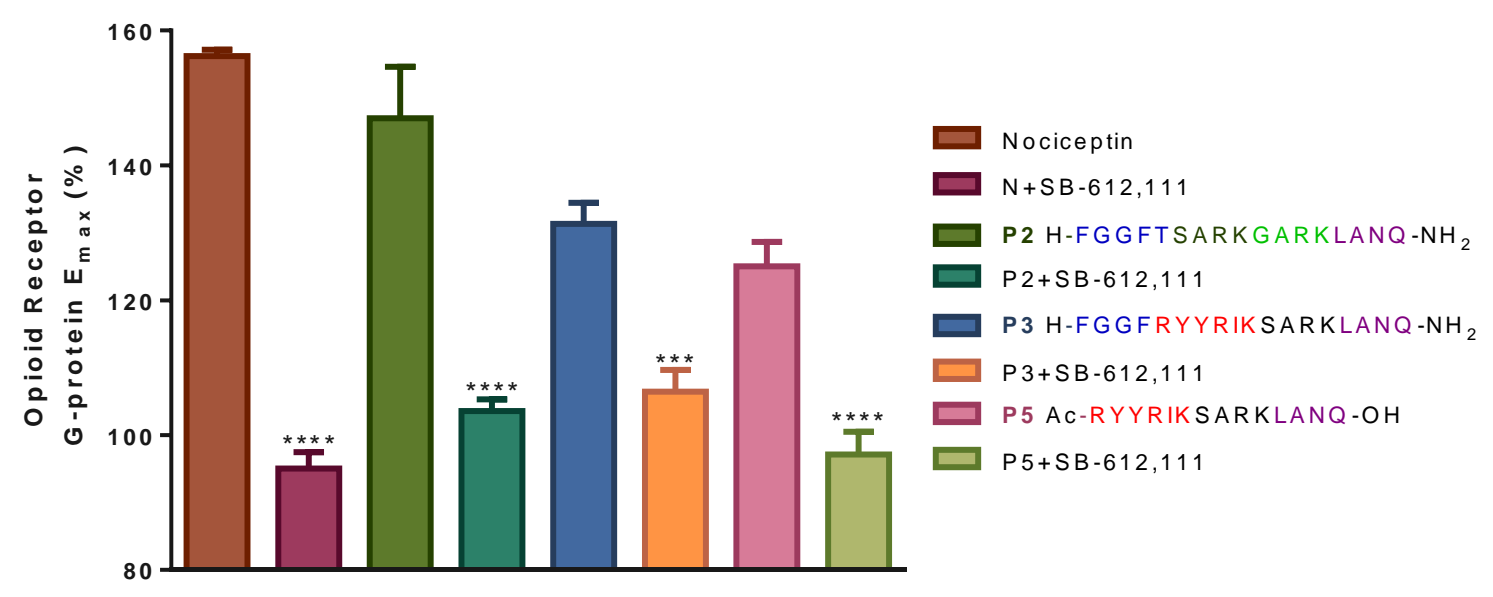

Fig. 10: Effect of SB-612,11 on the G-protein activation by the nociceptin hybrid peptides. Maximal stimulation $\left(E_{\max }\right)$ values were determined by analysing full dose-response curves. Columns shown represent mean values \pm S.E.M. SB-612,111 was used in $10 \mu \mathrm{M}$ concentration. ***: $\mathrm{p}<0.001$ and $* * * *: \mathrm{p}<0.0001$ vs. control groups (one-way ANOVA, Bonferroni’s multiple comparison post hoc test).

\section{MVD bioassay}

\subsection{Bifunctional ligands}

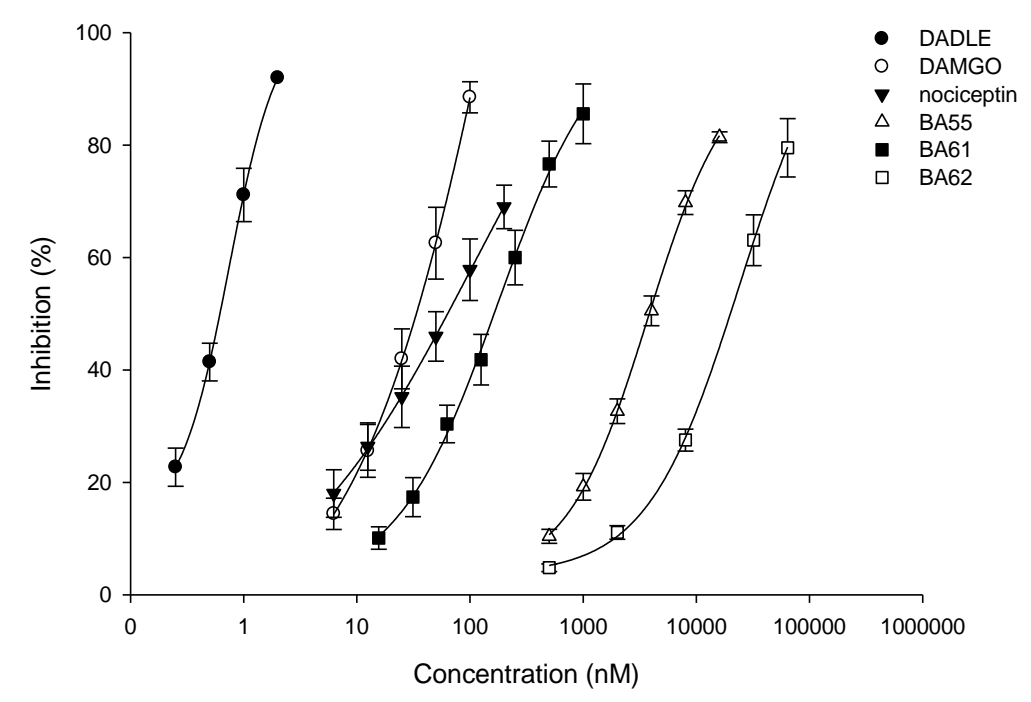

Fig. 11: Concentration-response curves for the bivalent peptides and reference opioid compounds on the electrically evoked contractions of the MVD. Data are presented as mean \pm S.E.M. 
In the MVD bioassay, BA61 was less potent than any of the reference compounds but about 24- and 121-fold more potent than BA55 or BA62. Ligand potencies were compared with control compounds using one-way ANOVA, and only BA61 was not different significantly from the controls.

The average $\mathrm{E}_{\max }$ was $100 \%$ for each compound tested in the present work (Fig. 11 and Table 12). Regarding sensitivity to $\mathrm{NX}$, it was found that the $\mathrm{NX} \mathrm{K}_{\mathrm{e}}$ values for the 3 ligands were between 3 and $20 \mathrm{nM}$, which indicates that the effects of the ligands are not mediated by the MOP receptor and these ligand may show selectivity to more than one opioid receptors.

When the $\mathrm{K}_{\mathrm{e}}$ values of NTI against BA55, BA61 and BA62 was determined, none of the ligands fell into the reference range for NTI $(0.057-0.12){ }^{171}$. However, the $K_{e}$ value of NTI against the ligand BA61 was very near to the upper limit of this range, which, together with the results of our other tests, may indicate that DOP receptor mediates the effect of this peptide. The $K_{e}$ value of nor-BNI against BA62 fell into the reference range $0.26-0.42{ }^{172}$, so BA62 may show a higher KOP receptor selectivity. The ligands (except BA61) were insensitive to JTC-801 antagonism.

Table 12: Characterization of the three bivalent peptide ligands and reference opioid agonist compounds in MVD bioassay.

\begin{tabular}{cccccc}
\hline Ligands & EC $_{\mathbf{5 0}}(\mathbf{n M})$ & \multicolumn{3}{c}{$\mathbf{K}_{\mathbf{e}}$ values for antagonists \pm S.E.M. (nM) } \\
& $\mathbf{\pm}$ S.E.M. & & & & \\
& & Naloxone (NX) & Naltrindole (NTI) & nor-BNI & JTC-801 \\
\hline DAMGO & $30 \pm 4$ & $1.01 \pm 0.14$ & n.d. & - & - \\
DADLE & $0.58 \pm 0.06$ & n.d. & $0.13 \pm 0.02$ & n.d. & - \\
EKC & $5.2 \pm 1.3$ & $7.9 \pm 0.54$ & $1.11 \pm 0.18$ & $0.51 \pm 0.05$ & - \\
N/OFQ & $62 \pm 4$ & - & - & - & $480 \pm 72$ \\
BA55 & $3860 \pm 9^{\mathrm{a}}$ & $14.05 \pm 2.7$ & $1.06 \pm 0.23$ & $1.25 \pm 0.41$ & - \\
BA61 & $160 \pm 6$ & $17.4 \pm 4.45$ & $0.16 \pm 0.02$ & $1.26 \pm 0.4$ & $3330 \pm 765^{\mathrm{c}}$ \\
BA62 & $19400 \pm 142^{\mathrm{b}}$ & $3.8 \pm 0.8$ & $1 \pm 0.3$ & $0.41 \pm 0.12$ & n.d. \\
\hline
\end{tabular}

The experiments were repeated at least three times. n.d.: not determined; - : no antagonist action.

a: Significantly different from all control compounds (****: $\mathrm{p}<0.0001)$ one-way ANOVA followed by Bonferroni's multiple comparison post hoc test.

b: Significantly different from all control compounds $(* * * *: \mathrm{p}<0.0001)$ one-way ANOVA followed by Bonferroni's multiple comparison post hoc test. 
c: Significantly different from JTC-801 (***: p<0.001) unpaired t-test followed by Welch's correction.

\subsection{Nociceptin analogues and nociceptin-RYYRIK hybrid peptides}

In the MVD bioassay we also attempted to clarify the agonist or antagonist activity of the nociceptin analogues and nociceptin-RYYRIK hybrid peptides.

As detailed in Table 13, the tested peptides except P2 showed slight inhibition only at high concentrations (i.e., $10 \mu \mathrm{M}$ ). Although P2 inhibited the twitch response slightly less than N/OFQ, it still indicated an agonist effect.

The $\mathrm{K}_{\mathrm{e}}$ value of P1 was significantly different from JTC-801 ( $\left.\mathrm{p}<0.001\right)$ but those of P4, P5, P6 and P7 were not. (Table 13). Moreover, P5, P6 and P4 could antagonize the effect of N/OFQ more effectively than control antagonist JTC-801, which displayed a negligible partial agonist activity in high concentration similar to P4, P5, P6 and P7.

Table 13: Effects of the nociceptin hybrid peptides and reference compounds on the electrically stimulated MVD.

\begin{tabular}{|c|c|c|c|}
\hline \multicolumn{2}{|c|}{ Ligands } & $\mathrm{EC}_{50}(\mathrm{nM} \pm$ S.E.M. $)$ & $\begin{array}{c}\text { Ke values for } \\
\text { antagonists } \pm \text { S.E.M. } \\
(\mathrm{nM})\end{array}$ \\
\hline \multicolumn{4}{|c|}{ Control compounds } \\
\hline \multicolumn{2}{|c|}{ N/OFQ } & $62 \pm 4$ & n.e. \\
\hline \multicolumn{2}{|c|}{ JTC-801 } & $>100000$ & $480 \pm 72$ \\
\hline \multicolumn{4}{|c|}{ Fused hybrid peptides } \\
\hline P1 & Ac-RYYRIKGARKLANQ-NH ${ }_{2}$ & $>10000$ & $1943 \pm 341^{\mathrm{a}}$ \\
\hline $\mathbf{P 2}$ & H-FGGFTSARKGARKLANQ-NH ${ }_{2}$ & $426 \pm 76^{\mathrm{b}}$ & n.e. \\
\hline P3 & H-FGGFRYYRIKSARKLANQ-NH 2 & $>1000000$ & n.e. \\
\hline P4 & Ac-RYYRIKSARKLANQ-NH ${ }_{2}$ & $>100000$ & $258 \pm 61$ \\
\hline P5 & Ac-RYYRIKSARKLANQ-OH & $>1000000$ & $136 \pm 26$ \\
\hline P6 & Ac-RYYRIKGARKSARKLANQ-OH & $>100000$ & $166 \pm 31$ \\
\hline P7 & Ac-RYYRIKGARKSARK-OH & $>1000000$ & $507 \pm 79$ \\
\hline P8 & H-FGGFGGGFGGF-NH ${ }_{2}$ & $>1000000$ & n.e. \\
\hline P9 & H-FGGFGGGRYYRIK-NH ${ }_{2}$ & $>1000000$ & n.e. \\
\hline
\end{tabular}

n.e.: no effect

a : Significantly different from JTC-801 (***: p<0.001), one-way ANOVA followed by Bonferroni's multiple comparison post hoc test.

b: Significantly different from N/OFQ $(*$ : p<0.05), unpaired t-test followed by Welch's correction. 


\section{DISCUSSION}

Since the discovery of morphine, no compound acting on the opioid receptors has been found which would retain morphine's advantageous properties without causing unwanted and often serious side effects characteristic for the opioids ${ }^{97,98}$.

Several mixed opioid compounds have so far been successfully used in human medicine $98,100,110$. This suggests that the development of ligands acting on multiple opioid receptors may help us reduce the different kinds of side effects and possibly amplify the therapeutic effect.

After the discovery of the N/OFQ-NOPr system it has been shown that this system influences the effects mediated by the classical opioid receptors, and is involved in the emergence of side effects $8,9,44,90,94,95$. Furthermore, the NOP receptor can heterodimerize with other opioid receptors ${ }^{13}$. These properties made the N/OFQ-NOPr system an important target of the development of pharmaceuticals. Our goal was to create such bifunctional ligands that target at least two different opioid receptors, one of which is the NOP receptor. In addition, we examined such hybrid peptides that target the NOP receptor only, because NOP receptor agonists and antagonists are known to influence opioid tolerance and dependence ${ }^{13,54-59}$. The results of all tested peptides were summarized in Table 14.

Three chimeric peptides (BA55, BA61 and BA62) were synthesized and studied in the current work. The classical opioid endopeptide message domain was selected as one of the building blocks, which is responsible for opioid receptor activation ${ }^{32,173-175}$. The other pharmacophore was based on artificial hexapeptide sequences isolated from a combinatorial peptide library ${ }^{176}$. It have been reported that this artificial hexapeptide Ac-RYYRIK-NH $\mathrm{NH}_{2}$ displayed NOP receptor partial agonist activity with full antagonist properties in the presence of the pure agonist N/OFQ ${ }^{67,81-83}$.

Ac-RYYRIK- $\mathrm{NH}_{2}$ has been in the focus of interest in studying the heterodimerization of opioid and NOP receptors and developing new therapeutic agents. Initially it was reported that TM helix 2 of the NOP receptor takes part in the recognition of Ac-RYYRIK- $\mathrm{NH}_{2}{ }^{65}$, but other molecular modelling and docking studies found that Ac-RYYRIK-NH${ }_{2}$ interacts with the binding pocket of the NOP receptor ${ }^{13}$, which implies that the binding sites of N/OFQ and RYYRIK may overlap ${ }^{67}$. One of the implications of this result is that hybrid peptides from the combination of RYYRIK and parts of nociceptin may bind to the NOP receptor with greater 
affinity than nociceptin itself. We designed, synthesized and characterized 9 such hybrid peptides (P1-P9).

In terms of binding affinity, the chimeric ligand BA55 exhibits KOP/NOP receptor preference, BA62 shows DOP/KOP receptor preference and BA61 indicates a DOP/KOP/NOP receptor preference, which is unexpected because BA61 has the opioid message domain YGGF hidden in the middle and not at the $\mathrm{N}$-terminus. An $\mathrm{N}$-terminal tyrosine (Tyr, $\mathrm{Y}$ ) is common to all known endogenous opioid peptides, such as $\beta$-endorphin, enkephalins, dynorphins and neoendorphins ${ }^{177}$. Moreover, the Leu-enkephalin pentapeptide (YGGFL) is at the C-terminus of BA61, so the C-terminal address region of this synthetic oligopeptide ligand has no positively charged amino acids important for the KOP-receptor recognition ${ }^{178,179}$.

The rank order of potency of the three peptides was BA61 > BA55> BA62 at the KOP receptor. The high KOP receptor activity of BA55 and BA62 is not surprising, since the accumulation of positively charged amino acid side chains (two arginines and one lysine, R..R.K) at the opioid address domain is present in various prodynorphin- (PDYN) derived endogenous opioid peptides ${ }^{180}$, including dynorphin A (RR...K.K), dynorphin B or rimorphin (RR..K...) and $\alpha$-neo-endorphin (RK..K). These data are consistent with our hypothesis that appropriate modifications in the address domain of dynorphin analogues may affect efficacy. Our results also confirm the importance of the opioid message domain displayed by many opioid ligands but also suggest a potential role of receptor recognition and activation that may be mediated by ECL2 through interactions with the address component of dynorphin-like peptides ${ }^{181}$. The high KOP receptor affinity was not observed among the Dooley's hexapeptide analogues described earlier ${ }^{67,82-84,182}$.

In the G-protein stimulation assays, BA55 and BA62 remained comparable agonists with Leu-enkephalin. The high efficacy is probably caused by the opioid message sequence (YGGF) at the N-terminus. BA61, which starts with Ac-RYYRIK-NH 2 , possesses slightly lower agonist properties than BA55 and BA62.

It is also worth to mention that in the $\left[{ }^{35} \mathrm{~S}\right] \mathrm{GTP} \gamma \mathrm{S}$ binding experiments, simple mixtures of the parent peptide components of the hybridised ligands behaved differently from the multitarget fused sequences bearing real chemical connections, i.e., covalent bonds. AcRYYRIK-NH $\mathrm{N}_{2}$ was able to inhibit the stimulation by Leu-enkephalin when it was present in the mixture, indicating that Dooley's peptide has opioid antagonist activity in addition to the well- 
known antagonism observed at NOP receptors ${ }^{80}$. However, in guinea pig brain membranes BA55 and BA62 mediated effects were surprisingly weaker than the effect of simply mixing the parent compounds.

BA55 and BA62 were significantly antagonized by nor-BNI in the $\left[{ }^{35} \mathrm{~S}\right] \mathrm{GTP} \gamma \mathrm{S}$ binding experiments while BA61 was not affected by the addition of nor-BNI. This phenomenon supports the KOP receptor preference of those hybrid peptides that contain the opioid message domain in the correct, N-terminal position. Interestingly, when the opioid tetrapeptide was located at the C terminus, i.e. in case of BA61, JTC-801, cyprodime and NTI significantly inhibited the stimulation. However, nor-BNI was unable to antagonize the stimulation of BA61, which indicates that the effect of BA61 is mediated only weakly by the KOP receptor. Cyprodime could not inhibit the effect of the BA55 and BA62, which indicates that the MOP receptor is weakly involved in mediating the effects of these two peptides.

We examined the pharmacological properties of the test peptides in mouse vas deferens (MVD), which includes all four opioid receptors, among which the DOP receptor is represented in the highest amounts ${ }^{183,184}$. The order of potency in this tissue was BA61 > BA55 > BA62, which matches what was determined in the binding assay. Applying different opioid receptor subtype antagonists revealed that BA55 and BA62 show non-selective opioid receptor subtype mediated action, whereas the agonist activity of BA61 is mediated mainly by DOPr and NOPr receptor. The selectivity of BA55 and BA62 for the DOP receptor was less than that of DADLE, indicated by equilibrium dissociation constants. The involvement of the DOP and the KOP receptor in the action of BA55 and BA62 is not surprising, since the two peptides have the same address and message domains. In contrast, BA61 has a different N-terminal domain, which prefers the NOP receptor ${ }^{67,81-83}$ and yet a different C-terminal one (carboxyl group), which is perhaps responsible for DOP receptor preference. This observation is in good agreement with previous results, according to which the free carboxyl group containing enkephalins preferred DOP receptors ${ }^{185,186}$. Consequently, the observed pharmacological effect of this peptide might result on these changes. The mouse vas deferens includes all four opioid receptors, but its DOPr content is the highest ${ }^{179,180}$. This tendency makes MVD very sensitive for the DOP receptor mediated effect of BA61. However, we could not perform such parallel measurements which would have shown us whether the NOP or the DOP receptor mediates the effect of BA61 in higher proportion. 
Another strategy for managing side effects caused by opioid drugs and for extending their analgesic effect is the development of NOP receptor agonists and antagonists, since the investigations have revealed that both NOP receptor agonists and antagonists have significant therapeutic potential in the treatment of tolerance and dependence ${ }^{13,51-53}$. Besides, compounds acting on the NOP receptor can be useful in the treatment of various diseases, since the N/OFQNOP receptor system regulates numerous different biological functions in different ways ${ }^{13,33-}$ 39.

The nine hybrid peptide variants (P1, P2 .. P9) were first studied in receptor binding assays. Compound P8 and P2, which did not contain Dooley's peptide (RYYRIK), had a different affinity for the NOP receptor. While compound P8 was unable to bind to NOP receptor, P2 showed a similar affinity to nociceptin. By synthesizing P8 our aim was to investigate whether we could create a functional ligand using only the message domains. However, the absence of the address domain resulted in a loss of binding ability because of the lack of some basic residues and other residues essential for binding ${ }^{32,173-175}$.

Of the other variants, containing RYYRIK, P1, P4, P5, P6 and P7 displaced $\left[{ }^{3} \mathrm{H}\right]$ Nociceptin with high affinity. P4, P6 and P7 showed better $\mathrm{K}_{\mathrm{i}}$ than even the parent peptides. The cause of these extremely high affinity values may well be that these 3 peptides combine the favourable properties of RYYRIK and N/OFQ. Kawano et al. found that RYYRIK is likely to interact with the site of the NOP receptor where N/OFQ(1-7) and N/OFQ(14-17) are involved 67. Experimental results show that Ac-RYYRIK-NH 2 binds to the NOP receptor with great affinity and it is probably the Ac-RYY residues are primarily responsible therefor ${ }^{67}$. Besides, P4, P6 and P7 also contain the nociceptin address domain, which is important in binding of N/OFQ, since it includes basic amino acids ${ }^{13,32}$. Thus, by fusion of RYYRIK and N/OFQ, we could combine their beneficial properties that may have contributed to the increase of affinity.

Although the amino acid sequences of variants P4 and P5 were the same (P4 was merely the amidated version of P5), P4 had a 7 times greater affinity than P5. This is in line with previous results showing that the truncated but amidated $\mathrm{N} / \mathrm{OFQ}(1-13) \mathrm{NH}_{2}$ exhibits a binding affinity and biological activity similar to the unmodified N/OFQ, in contrast with the unamidated truncated N/OFQ(1-13), which showed poorer affinity and activity ${ }^{10}$.

Comparing P1 and P4 peptides, the ligand P1, which contains $\mathrm{Gly}^{7}$ instead of $\mathrm{Ser}^{7}$, showed $30 \%$ lower $\mathrm{K}_{\mathrm{i}}$ value than $\mathrm{P} 4$ toward the NOP receptor. It is assumed that the apolar Gly 
at position 7 in the P1 ligand caused the reduction in affinity, since this is the only difference between the two peptides.

Although RYYRIK was reported to bind selectively to the NOP receptor, we aimed to investigate whether hybrid peptides made of RYYRIK fused with portions of N/OFQ could retain their selectivity, since the nociceptin address domain is also rich in positively charged side chains like in dynorphin, which selectively binds not to the NOP receptor but to the KOP receptor ${ }^{13}$. Among the tested peptides, only P1 and P7 showed affinity to MOP receptor in low concentration, which is surprised because the Ac-RYYRIK- $\mathrm{NH}_{2}$ was almost completely inactive at MOP receptor ${ }^{67}$.

In $\left[{ }^{35} \mathrm{~S}\right] \mathrm{GTP} \gamma \mathrm{S}$ assays, P8 acted as a weak partial agonist, several times less potent than N/OFQ, while the $E_{\max }$ value of P2 was little higher than that of N/OFQ.

It has been demonstrated in the case of N/OFQ that substituting the apolar neutral Gly ${ }^{6}$ to Ala may reduce potency by a slight amount ${ }^{62}$. Since potency has greatly decreased in our case, it is assumed that here the replacement of the apolar amino acid with a polar $\operatorname{Ser}^{6}$ was responsible for the large decrease.

P4, P6 and P7 showed weak agonist activity while P5 was a full agonist. Of the five variants, the best $\mathrm{EC}_{50}$ was shown by $\mathrm{P} 7$ and P5. We expected P4 (which was amidated at the $\mathrm{N}$-terminal end) to show full agonist activity. However, $\mathrm{P} 4$ showed low potency with low $\mathrm{E}_{\max }$ value, in contrast with our hypothesis.

Although P9 produced very weak efficacy, its potency was still strong. Conversely, P3 produced high $\mathrm{E}_{\max }$ value with a weak ligand potency.

Variants that showed full agonist activity were also tested for NOP receptor selectivity. To achieve this, SB-612,111 was used. The data clearly showed that the $\mathrm{E}_{\max }$ of P2, P3 and P5 were reduced significantly in the presence of the antagonist. This demonstrates that these ligands are NOP receptor-selective.

Following in vitro biochemical studies, the pharmacological effects of the variants were also investigated in MVD bioassays. Here the ligands did not exhibit agonist activity, except for P2. These results are surprising because the compounds proved to be promising in both binding and $\left[{ }^{35} \mathrm{~S}\right] \mathrm{GTP} \gamma \mathrm{S}$ tests based on the $\mathrm{K}_{\mathrm{i}}, \mathrm{EC}_{50}$ and $\mathrm{E}_{\max }$ values.

Only those ligands were expected to have antagonistic activity that contained RYYRIK at their N-terminal because RYYRIK itself acted as antagonist in previous $\left[{ }^{35} \mathrm{~S}\right] \mathrm{GTP} \gamma \mathrm{S}$ binding 
experiments and MVD bioassays ${ }^{67,81,187}$. Our results confirmed these expectations, as ligands that did not contain RYYRIK, or did contain RYYRIK but not at their N-termini, proved to be inactive (P3, P8, P9).

Summarizing the results, those ligands (P1, P4, P5, P6, P7) were the most potent antagonists that carry RYYRIK on the N-terminus. These results suggest that the binding sites of RYYRIK and N/OFQ may overlap. However, it cannot be ruled out that RYYRIK binds to the NOP receptor at the ECL2 or TM2 domain.

Despite the fact that P5 showed weaker affinity than P4 in the receptor binding tests, the receptor mediated $\mathrm{G}$ protein activation test showed full agonist activity, and its potency was more than two orders of magnitude higher than that of P4. The MVD bioassay also revealed that P5 acts as a more effective antagonist than P4. This contradicts our hypothesis that the amidation of the C-terminal increases the affinity and biological activity of N/OFQ peptide analogues ${ }^{10,30}$.

Ultimately, it is recommended to further investigate these peptides (P2, P5, P6 and P7) in vivo, since it cannot be ruled out that they might have agonistic effects, similarly to AcRYYRIK-NH ${ }_{2}$. 
Table 14: Results of the tested peptides from the different in vitro experiments

\begin{tabular}{|c|c|c|c|c|c|}
\hline \multirow{2}{*}{$\begin{array}{l}\text { Tested } \\
\text { peptides }\end{array}$} & \multirow{2}{*}{$\begin{array}{c}\text { Competition radioligand } \\
\text { binding assays }\end{array}$} & \multicolumn{2}{|c|}{ [35S]GTPYS binding assays } & \multicolumn{2}{|c|}{ MVD bioassays } \\
\hline & & $\begin{array}{l}\text { Agonist } \\
\text { activity }^{*}\end{array}$ & $\begin{array}{l}\text { Receptor-type } \\
\text { selectivity }\end{array}$ & $\begin{array}{l}\text { Agonist } \\
\text { activity }^{*}\end{array}$ & $\begin{array}{l}\text { Receptor- } \\
\text { type } \\
\text { selectivity }\end{array}$ \\
\hline BA55 & $\mathrm{KOPr} / \mathrm{NOPr}$ & \multirow{2}{*}{ full } & \multirow{2}{*}{$\mathrm{DOPr} / \mathrm{KOPr} / \mathrm{NOPr}$} & \multirow{4}{*}{ agonist } & DOPr / KOPr \\
\hline BA62 & DOPr / KOPr & & & & $\mathrm{K} \cap \mathrm{Pr}$ \\
\hline \multirow{2}{*}{ BA61 } & \multirow{2}{*}{ DOPr / NOPr } & \multirow{2}{*}{$\begin{array}{l}\text { partial/ } \\
\text { full }\end{array}$} & \multirow{2}{*}{ MOPr / DOPr / NOPr } & & . \\
\hline & & & & & DOPr / NOPr \\
\hline \multicolumn{2}{|c|}{ Affinity on NOPr } & \multirow{3}{*}{ partial } & \multirow{10}{*}{ NOPr } & \multirow{6}{*}{\multicolumn{2}{|c|}{$\begin{array}{l}\text { Partial agonist activity on } \\
\text { NOPr, but antagonist activity } \\
\text { in the presence of N/OFQ }\end{array}$}} \\
\hline $\mathbf{P 1}$ & $\begin{array}{l}\text { Similar to the parent } \\
\text { compounds }\end{array}$ & & & & \\
\hline P4 & $\begin{array}{l}\text { Greater than the parent } \\
\text { compounds }\end{array}$ & & & & \\
\hline P5 & $\begin{array}{l}\text { Similar to parent } \\
\text { compounds }\end{array}$ & full & & & \\
\hline P6 & \multirow{3}{*}{$\begin{array}{l}\text { Greater than the parent } \\
\text { compounds }\end{array}$} & \multirow{2}{*}{ partial } & & & \\
\hline P7 & & & & & \\
\hline P2 & & \multirow[b]{2}{*}{ full } & & \multirow{2}{*}{\multicolumn{2}{|c|}{ Agonist activity on NOPr }} \\
\hline P3 & Slightly weaker than the & & & & \\
\hline P8 & \multirow{2}{*}{ Weak } & \multirow{2}{*}{ partial } & & \multirow{2}{*}{\multicolumn{2}{|c|}{-}} \\
\hline P9 & & & & & \\
\hline
\end{tabular}

* G-protein activation studies were performed in rat brain membrane homogenates. 


\section{SUMMARY}

\section{Bifunctional ligands}

- We concluded that the three bifunctional ligands bound to the DOP, KOP, NOP receptors even in a small concentration. BA55 had the highest affinity to the KOP and NOP receptors, BA61 to the NOP and DOP receptors, and BA62 to the DOP and KOP receptors.

- The G-protein activation tests showed that both BA55 and BA62 stimulated the Gproteins effectively, which was mediated by the DOP, KOP and NOP receptors. The stimulation of G-proteins by BA61 was weaker, and could be mediated through the DOP and NOP receptors, and, to a lesser extent, the MOP receptor.

- Based on the results of the MVD bioassays, we deduced that all three ligands preferred the DOP and KOP receptors to the MOP and NOP receptors. According to the $\mathrm{K}_{\mathrm{e}}$ values, BA61 showed the highest agonist activity on the DOP receptor, while BA62 was the strongest agonist of the KOP receptor. Despite our prior expectations, only BA61 showed a - rather weak agonist effect on the NOP receptor.

\section{Nociceptin analogues and nociceptin-RYYRIK hybrid peptides}

- The radioligand competition binding assays showed that the ligands that showed greater NOP receptor affinity than the parent compounds were P1, P2, P4, P6 and P7.

- In the G-protein activation tests, the $\mathbf{P 2}$ and $\mathbf{P 3}$ peptides showed full agonist effect on the NOP receptor. The remaining 7 peptides behaved as partial agonists.

- In the MVD bioassay P4, P5, P6 and P7 behaved as partial agonists. P4, P5 and P6 inhibited the effect of N/OFQ to a greater extent than the control JTC-801. 


\section{CONCLUSION}

Bivalent ligands acting on opioid receptors are an important area of research, since mixed compounds similar to bivalent ligands have already been used successfully in human medicine. In addition, compounds acting on the NOP receptor play a crucial role in the investigation of the NOP-N/OFQ system and its physiological effects, such as tolerance and dependence.

We have synthesized novel bifunctional ligand candidates, among which BA61 proved to be promising as it was able to bind to the DOP receptor and weakly to the NOP receptor. Among the 9 N/OFQ variants, P4, P5, P6, and P7 were efficient NOP receptor antagonists. Further in vitro and in vivo studies, such as rat tail-flick tests and gastrointestinal transit tests are needed to understand the exact pharmacology and possible clinical utility of the above mentioned peptides. 


\section{REFERENCES}

1. Mollereau, C. et al. ORL1, a novel member of the opioid receptor family: Cloning, functional expression and localization. FEBS Lett. 341, 33-38 (1994).

2. Bunzow, J. R. et al. Molecular cloning and tissue distribution of a putative member of the rat opioid receptor gene family that is not a $\mu, \delta$ or $\kappa$ opioid receptor type. FEBS Lett. 347, 284-288 (1994).

3. Mollereau, C. et al. ORL1, a novel member of the opioid receptor family. Cloning, functional expression and localization. FEBS Lett. (1994). doi:10.1016/00145793(94)80235-1

4. Nishi, M., Takeshima, H., Mori, M., Nakagawara, K. \& Takeuchi, T. Structure and Chromosomal Mapping of Genes for the Mouse $\kappa$-Opioid Receptor and an Opioid Receptor Homologue (MOR-C). Biochem. Biophys. Res. Commun. 205, 1353-1357 (1994).

5. Wang, J. B. et al. cDNA cloning of an orphan opiate receptor gene family member and its splice variant. FEBS Lett. 348, 75-9 (1994).

6. Fukuda, K., Kato, S., Morikawa, H., Shoda, T. \& Mori, K. Functional coupling of the delta-, mu-, and kappa-opioid receptors to mitogen-activated protein kinase and arachidonate release in Chinese hamster ovary cells. J. Neurochem. 67, 1309-16 (1996).

7. Civelli, O., Saito, Y., Wang, Z., Nothacker, H.-P. \& Reinscheid, R. K. Orphan GPCRs and their ligands. Pharmacol. Ther. 110, 525-532 (2006).

8. Meunier, J. C. et al. Isolation and structure of the endogenous agonist of opioid receptor-like ORL1 receptor. Nature 377, 532-5 (1995).

9. Reinscheid, R. K. et al. Orphanin FQ: a neuropeptide that activates an opioidlike G protein-coupled receptor. Science 270, 792-4 (1995).

10. Calo, G. \& Guerrini, R. Medicinal chemistry, pharmacology, and biological actions of peptide Ligands selective for the nociceptin/orphanin FQ receptor. ACS Symp. Ser. 1131, 275-325 (2013).

11. Cox, B. M.; Chavkin, C.; Christie, M. J.; Civelli, O.; Evans, C. . H., M. D.; Hoellt, V.; Kieffer, B.; Kitchen, I.; McKnight, A. T.; Meunier, J. C. . \& Portoghese, P. S. Opioidreceptors. TheIUPHARCompendiumofReceptor Charact. Classif. 2nd ed.; G, pp 321-333 (2000).

12. Calo', G., Guerrini, R., Rizzi, A., Salvadori, S. \& Regoli, D. Pharmacology of nociceptin and its receptor: a novel therapeutic target. Br. J. Pharmacol. 129, 12611283 (2000).

13. Toll, L., Bruchas, M. R., Calo, G., Cox, B. M. \& Zaveri, N. T. Nociceptin / Orphanin FQ Receptor Structure, Signaling, Ligands , Functions , and Interactions with Opioid Systems. 034929, 419-457 (2016). 
14. Meunier, J., Mouledous, L. \& Topham, C. M. The nociceptin (ORL1) receptor: molecular cloning and functional architecture. Peptides 21, 893-900 (2000).

15. Manglik, A. et al. Crystal structure of the $\mu$-opioid receptor bound to a morphinan antagonist. Nature 485, 321-6 (2012).

16. Provasi, D., Bortolato, A. \& Filizola, M. Exploring molecular mechanisms of ligand recognition by opioid receptors with metadynamics. Biochemistry 48, 10020-9 (2009).

17. Vardy, E. et al. Chemotype-selective modes of action of $\kappa$-opioid receptor agonists. $J$. Biol. Chem. 288, 34470-83 (2013).

18. Filizola, M. \& Devi, L. A. Grand opening of structure-guided design for novel opioids. Trends Pharmacol. Sci. 34, 6-12 (2013).

19. Daga, P. R. \& Zaveri, N. T. Homology modeling and molecular dynamics simulations of the active state of the nociceptin receptor reveal new insights intoagonist binding and activation. Proteins Struct. Funct. Bioinforma. 80, n/a-n/a (2012).

20. Mollereau, C. et al. Distinct mechanisms for activation of the opioid receptor-like 1 and kappa-opioid receptors by nociceptin and dynorphin A. Mol. Pharmacol. 55, 324 31 (1999).

21. Mollereau, C. et al. Structure, tissue distribution, and chromosomal localization of the prepronociceptin gene. Proc. Natl. Acad. Sci. U. S. A. 93, 8666-70 (1996).

22. Nothacker, H. P. et al. Primary structure and tissue distribution of the orphanin FQ precursor. Proc. Natl. Acad. Sci. U. S. A. 93, 8677-82 (1996).

23. Zaveri, N. T., Green, C. J. \& Toll, L. Transcriptional Regulation of the Human Prepronociceptin Gene. Biochem. Biophys. Res. Commun. 276, 710-717 (2000).

24. Mollereau, C. et al. Structure, tissue distribution, and chromosomal localization of the prepronociceptin gene. Neurobiology 93, (1996).

25. Florin, S., Suaudeau, C., Meunier, J. C. \& Costentin, J. Orphan neuropeptide NocII, a putative pronociceptin maturation product, stimulates locomotion in mice. Neuroreport 8, 705-7 (1997).

26. Rossi, G. C., Mathis, J. P. \& Pasternak, G. W. Analgesic activity of orphanin FQ2, murine prepro-orphanin FQ141-157 in mice. Neuroreport 9, 1165-8 (1998).

27. Okuda-Ashitaka, E. \& Ito, S. Nocistatin: a novel neuropeptide encoded by the gene for the nociceptin/orphanin FQ precursor. Peptides 21, 1101-9 (2000).

28. Hiramatsu, M. \& Inoue, K. Effects of nocistatin on nociceptin-induced impairment of learning and memory in mice. Eur. J. Pharmacol. 367, 151-5 (1999).

29. Sakurada, C., Sakurada, S., Orito, T., Tan-No, K. \& Sakurada, T. Degradation of nociceptin (orphanin FQ) by mouse spinal cord synaptic membranes is triggered by endopeptidase-24.11: an in vitro and in vivo study. Biochem. Pharmacol. 64, 1293-303 (2002).

30. Zaveri, N. Peptide and nonpeptide ligands for the nociceptin/orphanin FQ receptor ORL1: research tools and potential therapeutic agents. Life Sci. 73, 663-78 (2003). 
31. Montiel, J. L., Cornille, F., Roques, B. P. \& Noble, F. Nociceptin/orphanin FQ metabolism: role of aminopeptidase and endopeptidase 24.15. J. Neurochem. 68, 354 61 (1997).

32. Remo Guerrini, $\uparrow$ et al. Address and Message Sequences for the Nociceptin Receptor: A Structure-Activity Study of Nociceptin-(1-13)-peptide amide. (1997). doi:10.1021/JM970011B

33. Serrano-Gomez, A., Thompson, J. P. \& Lambert, D. G. Nociceptin/orphanin FQ in inflammation and sepsis. Br. J. Anaesth. 106, 6-12 (2011).

34. Kapusta, D. R., Sezen, S. F., Chang, J. K., Lippton, H. \& Kenigs, V. A. Diuretic and antinatriuretic responses produced by the endogenous opioid-like peptide, nociceptin (orphanin FQ). Life Sci. 60, PL15-21 (1997).

35. Bigoni, R. et al. Characterization of nociceptin receptors in the periphery: in vitro and in vivo studies. Naunyn. Schmiedebergs. Arch. Pharmacol. 359, 160-167 (1999).

36. Osinski, M. A., Pampusch, M. S., Murtaugh, M. P. \& Brown, D. R. Cloning, expression and functional role of a nociceptin/orphanin FQ receptor in the porcine gastrointestinal tract. Eur. J. Pharmacol. 365, 281-9 (1999).

37. Fischer, A., Forssmann, W. G. \& Undem, B. J. Nociceptin-induced inhibition of tachykinergic neurotransmission in guinea pig bronchus. J. Pharmacol. Exp. Ther. 285, 902-7 (1998).

38. Baiula, M., Bedini, A. \& Carbonari, G. Send Orders of Reprints at reprints@benthamscience.net Molecular Mechanisms Mediating Nociceptin/Orphanin FQ Receptor Sig-naling, Desensitization and Internalization. Current Molecular Pharmacology 5, (2012).

39. Kadhim, S., Bird, M. F. \& Lambert, D. G. in (2019). doi:10.1007/164_2018_203

40. O’Brien, J. M., Ali, N. A., Aberegg, S. K. \& Abraham, E. Sepsis. Am. J. Med. 120, 1012-1022 (2007).

41. Neal, C. R. et al. Opioid receptor-like (ORL1) receptor distribution in the rat central nervous system: comparison of ORL1 receptor mRNA expression with (125)I[(14)Tyr]-orphanin FQ binding. J. Comp. Neurol. 412, 563-605 (1999).

42. Mollereau, C. \& Mouledous, L. Tissue distribution of the opioid receptor-like (ORL1) receptor. Peptides 21, 907-17 (2000).

43. Florin, S., Meunier, J. \& Costentin, J. Autoradiographic localization of [3H]nociceptin binding sites in the rat brain. Brain Res. 880, 11-6 (2000).

44. Morgan, D. O. CYCLIN-DEPENDENT KINASES: Engines, Clocks, and Microprocessors. Annu. Rev. Cell Dev. Biol. 13, 261-291 (1997).

45. Hao, J. X., Xu, I. S., Wiesenfeld-Hallin, Z. \& Xu, X. J. Anti-hyperalgesic and antiallodynic effects of intrathecal nociceptin/orphanin FQ in rats after spinal cord injury, peripheral nerve injury and inflammation. Pain 76, 385-93 (1998).

46. Corradini, L., Briscini, L., Ongini, E. \& Bertorelli, R. The putative OP4 antagonist, [Nphe1]nociceptin(1-13)NH2, prevents the effects of nociceptin in neuropathic rats. 
Brain Res. 905, 127-133 (2001).

47. Rizzi, A. et al. Pharmacological Characterization of the Nociceptin / Orphanin FQ Receptor Antagonist SB-612111 [( $\checkmark$ ) - cis -1-Methyl-7- [[ 4- 5 H -benzocyclohepten5-ol ]: In Vivo Studies. J. Pharmacol. Exp. Ther. 321, 968-974 (2007).

48. Di Giannuario, A. et al. Studies on the antinociceptive effect of [Nphe1]nociceptin(113)NH2 in mice. Neurosci. Lett. 316, 25-8 (2001).

49. Tamai, H., Sawamura, S., Takeda, K., Orii, R. \& Hanaoka, K. Anti-allodynic and antihyperalgesic effects of nociceptin receptor antagonist, JTC-801, in rats after spinal nerve injury and inflammation. Eur. J. Pharmacol. 510, 223-228 (2005).

50. Calo', G. et al. Pharmacological profile of nociceptin/orphanin FQ receptors. Clin. Exp. Pharmacol. Physiol. 29, 223-8 (2002).

51. Scoto, G. M., Aricò, G., Iemolo, A., Ronsisvalle, G. \& Parenti, C. Selective inhibition of the NOP receptor in the ventrolateral periaqueductal gray attenuates the development and the expression of tolerance to morphine-induced antinociception in rats. Peptides 31, 696-700 (2010).

52. Zaratin, P. F. et al. Modification of nociception and morphine tolerance by the selective opiate receptor-like orphan receptor antagonist (-)-cis-1-methyl-7-[[4-(2,6dichlorophenyl)piperidin-1-yl]methyl]-6,7,8,9-tetrahydro-5H-benzocyclohepten-5-ol (SB-612111). J. Pharmacol. Exp. Ther. 308, 454-61 (2004).

53. Chung, S., Pohl, S., Zeng, J., Civelli, O. \& Reinscheid, R. K. Endogenous Orphanin FQ/Nociceptin Is Involved in the Development of Morphine Tolerance. J. Pharmacol. Exp. Ther. 318, 262-267 (2006).

54. Lutfy, K. \& Zaveri, N. T. The Nociceptin Receptor as an Emerging Molecular Target for Cocaine Addiction. Progress in Molecular Biology and Translational Science 137, (Elsevier Inc., 2016).

55. Ciccocioppo, R., Angeletti, S., Sanna, P. P., Weiss, F. \& Massi, M. Effect of nociceptin/orphanin FQ on the rewarding properties of morphine. Eur. J. Pharmacol. 404, 153-9 (2000).

56. Kotlińska, J., Wichmann, J., Legowska, A., Rolka, K. \& Silberring, J. Orphanin FQ/nociceptin but not Ro 65-6570 inhibits the expression of cocaine-induced conditioned place preference. Behav. Pharmacol. 13, 229-35 (2002).

57. Kotlinska, J. et al. Nociceptin inhibits acquisition of amphetamine-induced place preference and sensitization to stereotypy in rats. Eur. J. Pharmacol. 474, 233-9 (2003).

58. Zhao, R.-J. et al. Orphanin FQ/nociceptin blocks methamphetamine place preference in rats. Neuroreport 14, 2383-5 (2003).

59. Sakoori, K. \& Murphy, N. P. Central administration of nociceptin/orphanin FQ blocks the acquisition of conditioned place preference to morphine and cocaine, but not conditioned place aversion to naloxone in mice. Psychopharmacology (Berl). 172, 129-136 (2004).

60. Ciccocioppo, R. et al. Attenuation of ethanol self-administration and of conditioned 
reinstatement of alcohol-seeking behaviour by the antiopioid peptide nociceptin/orphanin FQ in alcohol-preferring rats. Psychopharmacology (Berl). 172, 170-178 (2004).

61. de Guglielmo, G., Martin-Fardon, R., Teshima, K., Ciccocioppo, R. \& Weiss, F. MT7716, a potent NOP receptor agonist, preferentially reduces ethanol seeking and reinforcement in post-dependent rats. Addict. Biol. 20, 643-651 (2015).

62. Mustazza, C. \& Bastanzio, G. Development of nociceptin receptor (NOP) agonists and antagonists. Med. Res. Rev. 31, 605-648 (2011).

63. Calo', G. et al. Structure-Activity Study of the Nociceptin(1-13)-NH 2 N-Terminal Tetrapeptide and Discovery of a Nociceptin Receptor Antagonist. J. Med. Chem. 41, 3360-3366 (1998).

64. Salvadori, S., Guerrini, R., Calo, G. \& Regoli, D. Structure-activity studies on nociceptin/orphanin FQ: from full agonist, to partial agonist, to pure antagonist. Farmaco 54, 810-25 (1999).

65. Dooley, C. T. et al. Binding and in vitro activities of peptides with high affinity for the nociceptin/orphanin FQ receptor, ORL1. J. Pharmacol. Exp. Ther. 283, 735-41 (1997).

66. Whiteside, G. T. \& Kyle, D. J. A Review of the NOP (ORL-1)-nociceptin/orphanin FQ system covering receptor structure, distribution, role in analgesia and reward and interactions with other receptors. ACS Symp. Ser. 1131, 327-368 (2013).

67. Kawano, C. et al. Structural requirements of nociceptin antagonist Ac-RYYRIK-NH2 for receptor binding. J. Pept. Sci. 8, 561-9 (2002).

68. Akuzawa, N., Takeda, S. \& Ishiguro, M. Structural modelling and mutation analysis of a nociceptin receptor and its ligand complexes. J. Biochem. 141, 907-16 (2007).

69. Boulevard, T. et al. Former Editors University of California University of Edinburgh University of Chicago University of North Carolina University of Liverpool School of Medicine State University of New York at Stony Brook National Institute of Department of Biochemistry Emor. (2014).

70. Bes, B. \& Meunier, J.-C. Identification of a hexapeptide binding region in the nociceptin (ORL1) receptor by photo-affinity labelling with Ac-Arg-Bpa-Tyr-Arg-TrpArg-NH2. Biochem. Biophys. Res. Commun. 310, 992-1001 (2003).

71. Nociceptin Opioid. 6, (Elsevier Science, 2015).

72. Thomsen, C. et al. [3H]ac-RYYRWK-NH2, a novel specific radioligand for the nociceptin/orphanin FQ receptor. Naunyn. Schmiedebergs. Arch. Pharmacol. 362, 53845 (2000).

73. Judd, A. K. et al. N-terminal modifications leading to peptide ORL1 partial agonists and antagonists. J. Pept. Res. 62, 191-8 (2003).

74. Judd, A. K. et al. Structure-activity studies on high affinity NOP-active hexapeptides. J. Pept. Res. 64, 87-94 (2004).

75. Carra', G. et al. Tryptophan replacement in the nociceptin/orphanin FQ receptor ligand Ac-RYYRWK-NH2. J. Pept. Res. 66, 39-47 (2008). 
76. Kapusta, D. R. et al. Pharmacodynamic characterization of ZP120 (AcRYYRWKKKKKKK-NH2), a novel, functionally selective nociceptin/orphanin FQ peptide receptor partial agonist with sodium-potassium-sparing aquaretic activity. $J$. Pharmacol. Exp. Ther. 314, 652-60 (2005).

77. Rizzi, A. et al. Pharmacological characterization of the novel nociceptin/orphanin FQ receptor ligand, ZP120: in vitro and in vivo studies in mice. Br. J. Pharmacol. 137, 369-74 (2002).

78. Villar, I. C. et al. Functional pharmacological characterization of SER100 in cardiovascular health and disease. Br. J. Pharmacol. 173, 3386-3401 (2016).

79. Kantola, I., Scheinin, M., Gulbrandsen, T., Meland, N. \& Smerud, K. T. Safety, Tolerability, and Antihypertensive Effect of SER100, an Opiate Receptor-Like 1 (ORL-1) Partial Agonist, in Patients With Isolated Systolic Hypertension. Clin. Pharmacol. Drug Dev. 6, 584-591 (2017).

80. Berger, H., Albrecht, E., Wallukat, G. \& Bienert, M. Antagonism by acetyl-RYYRIK$\mathrm{NH} 2$ of $\mathrm{G}$ protein activation in rat brain preparations and of chronotropic effect on rat cardiomyocytes evoked by nociceptin/orphanin FQ. Br. J. Pharmacol. 126, 555-8 (1999).

81. Berger, H. et al. The nociceptin/orphanin FQ receptor ligand acetyl-RYYRIK-amide exhibits antagonistic and agonistic properties. Peptides 21, 1131-9 (2000).

82. Kocsis, L. et al. Nociceptin antagonism: probing the receptor by $\mathrm{N}$-acetyl oligopeptides. Regul. Pept. 122, 199-207 (2004).

83. Gündüz, Ö. et al. In vitro binding and functional studies of Ac-RYYRIK-ol and its derivatives, novel partial agonists of the nociceptin/orphanin F/Q receptor. NeuroSignals 15, 91-101 (2006).

84. Gündüz, O. et al. In vitro and in vivo pharmacological characterization of the nociceptin/orphanin FQ receptor ligand Ac-RYYRIK-ol. Eur. J. Pharmacol. 539, 3948 (2006).

85. Kawano, S., Ambo, A. \& Sasaki, Y. Synthesis and receptor binding properties of chimeric peptides containing a mu-opioid receptor ligand and nociceptin/orphanin FQ receptor ligand Ac-RYYRIK-amide. Bioorg. Med. Chem. Lett. 16, 4839-41 (2006).

86. Guillemyn, K. et al. Bifunctional Peptide-Based Opioid Agonist-Nociceptin Antagonist Ligands for Dual Treatment of Acute and Neuropathic Pain. J. Med. Chem. 59, 377792 (2016).

87. Lagard, C. et al. Bifunctional peptide-based opioid agonist/nociceptin antagonist ligand for dual treatment of nociceptive and neuropathic pain. Pain 158, 505-515 (2017).

88. Liu, Z., Zhang, J. \& Zhang, A. Design of Multivalent Ligand Targeting G-ProteinCoupled Receptors. Curr. Pharm. Des. 15, 682-718 (2009).

89. Starnowska, J. et al. Bifunctional opioid/nociceptin hybrid KGNOP1 effectively attenuates pain-related behaviour in a rat model of neuropathy. Eur. J. Pharm. Sci. 104, 221-229 (2017).

90. Pan, Y.-X., Bolan, E. \& Pasternak, G. W. Dimerization of morphine and orphanin 
FQ/nociceptin receptors: generation of a novel opioid receptor subtype. Biochem. Biophys. Res. Commun. 297, 659-63 (2002).

91. Wang, H.-L. et al. Heterodimerization of opioid receptor-like 1 and $\mu$-opioid receptors impairs the potency of $\mu$ receptor agonist. J. Neurochem. 92, 1285-1294 (2005).

92. Evans, R. M. et al. Heterodimerization of ORL1 and opioid receptors and its consequences for N-type calcium channel regulation. J. Biol. Chem. 285, 1032-40 (2010).

93. Evans, R. M. et al. Heterodimerization of ORL1 and opioid receptors and its consequences for N-type calcium channel regulation. J. Biol. Chem. 285, 1032-40 (2010).

94. Mandyam, C. D., Thakker, D. R., Christensen, J. L. \& Standifer, K. M. Orphanin FQ/Nociceptin-Mediated Desensitization of Opioid Receptor-Like 1 Receptor and micro Opioid Receptors Involves Protein Kinase C: A Molecular Mechanism for Heterologous Cross-Talk. J. Pharmacol. Exp. Ther. 302, 502-509 (2002).

95. Ozsoy, H. Z., Thakker, D. R. \& Standifer, K. M. Enkephalin - Induced $\square$-Opioid Receptor Phosphorylation. 68, 447-456 (2005).

96. Thakker, D. R. \& Standifer, K. M. Induction of G protein-coupled receptor kinases 2 and 3 contributes to the cross-talk between mu and ORL1 receptors following prolonged agonist exposure. Neuropharmacology 43, 979-90 (2002).

97. Brownstein, M. J. Review A brief history of opiates, opioid peptides, and opioid receptors. Proc. Natl. Acad. Sci. USA 90, (1993).

98. Rosenblum, A., Marsch, L. A., Joseph, H. \& Portenoy, R. K. Opioids and the treatment of chronic pain: controversies, current status, and future directions. Exp. Clin. Psychopharmacol. 16, 405-16 (2008).

99. Pasternak, G. \& Pan, Y.-X. Mu opioid receptors in pain management. Acta Anaesthesiol. Taiwan 49, 21-5 (2011).

100. Mcdonald, J., Lambert, D. G. \& Frca, P. Opioid receptors. Br. J. Anaesth. Educ. 15, 219-224 (2015).

101. Codeine Side Effects in Detail - Drugs.com. Available at: https://www.drugs.com/sfx/codeine-side-effects.html. (Accessed: 7th March 2019)

102. Fentanyl Side Effects in Detail - Drugs.com. Available at: https://www.drugs.com/sfx/fentanyl-side-effects.html. (Accessed: 7th March 2019)

103. Levorphanol Side Effects in Detail - Drugs.com. Available at: https://www.drugs.com/sfx/levorphanol-side-effects.html. (Accessed: 7th March 2019)

104. Common Side Effects of Demerol (Meperidine) Drug Center - RxList. Available at: https://www.rxlist.com/demerol-side-effects-drug-center.htm. (Accessed: 7th March 2019)

105. Common Side Effects of Dolophine (Methadone Tablets) Drug Center - RxList. Available at: https://www.rxlist.com/methadone-hydrochloride-side-effects-drugcenter.htm. (Accessed: 7th March 2019) 
106. Morphine Side Effects in Detail - Drugs.com. Available at: https://www.drugs.com/sfx/morphine-side-effects.html. (Accessed: 7th March 2019)

107. Oxycodone Side Effects in Detail - Drugs.com. Available at: https://www.drugs.com/sfx/oxycodone-side-effects.html. (Accessed: 7th March 2019)

108. Oxymorphone Side Effects in Detail - Drugs.com. Available at: https://www.drugs.com/sfx/oxymorphone-side-effects.html. (Accessed: 7th March 2019)

109. Tramadol Side Effects in Detail - Drugs.com. Available at: https://www.drugs.com/sfx/tramadol-side-effects.html. (Accessed: 7th March 2019)

110. Brownstein, M. J. Review A brief history of opiates, opioid peptides, and opioid receptors. Proc. Natl. Acad. Sci. USA 90, (1993).

111. Negus, S. S. et al. Delta opioid antagonist effects of buprenorphine in rhesus monkeys. Behav. Pharmacol. 13, 557-70 (2002).

112. Leander, J. D. Buprenorphine has potent kappa opioid receptor antagonist activity. Neuropharmacology 26, 1445-7 (1987).

113. Virk, M. S., Arttamangkul, S., Birdsong, W. T. \& Williams, J. T. Buprenorphine is a weak partial agonist that inhibits opioid receptor desensitization. J. Neurosci. 29, 7341-8 (2009).

114. Kallupi, M. et al. Buprenorphine requires concomitant activation of NOP and MOP receptors to reduce cocaine consumption. Addict. Biol. 23, 585-595 (2018).

115. Buprenorphine Side Effects in Detail - Drugs.com. Available at: https://www.drugs.com/sfx/buprenorphine-side-effects.html. (Accessed: 7th March 2019)

116. O'CONNOR, J. J., MOLONEY, E., TRAVERS, R. \& CAMPBELL, A. Buprenorphine Abuse Among Opiate Addicts. Addiction 83, 1085-1087 (1988).

117. Fischer, J. \& Ganellin, C. R. (C. R. Analogue-based drug discovery. (Wiley-VCH, 2006).

118. Butorphanol Side Effects in Detail - Drugs.com. Available at: https://www.drugs.com/sfx/butorphanol-side-effects.html. (Accessed: 7th March 2019)

119. Jaw, S. P., Hoskins, B. \& Ho, I. K. Opioid antagonists and butorphanol dependence. Pharmacol. Biochem. Behav. 44, 497-500 (1993).

120. Lewis, J. R. Evaluation of New Analgesics. JAMA 243, 1465 (1980).

121. De Souza, E. B., Schmidt, W. K. \& Kuhar, M. J. Nalbuphine: an autoradiographic opioid receptor binding profile in the central nervous system of an agonist/antagonist analgesic. J. Pharmacol. Exp. Ther. 244, 391-402 (1988).

122. Nalbuphine Side Effects in Detail - Drugs.com. Available at: https://www.drugs.com/sfx/nalbuphine-side-effects.html. (Accessed: 7th March 2019)

123. Cohen, B. M. \& Murphy, B. The effects of pentazocine, a kappa agonist, in patients with mania. Int. J. Neuropsychopharmacol. 11, 243-247 (2008). 
124. Pentazocine Side Effects in Detail - Drugs.com. Available at: https://www.drugs.com/sfx/pentazocine-side-effects.html. (Accessed: 7th March 2019)

125. Showalter, C. V. Abuse of Pentazocine and Tripelennamine. JAMA J. Am. Med. Assoc. 239, 1610 (1978).

126. Dvoracsko, S., Stefanucci, A., Novellino, E. \& Mollica, A. c. Future Med. Chem. 7, 2469-83 (2015).

127. Corson, T. W., Aberle, N. \& Crews, C. M. Design and Applications of Bifunctional Small Molecules: Why Two Heads Are Better Than One. ACS Chem. Biol. 3, 677-692 (2008).

128. Dietis, N. et al. Simultaneous targeting of multiple opioid receptors: a strategy to improve side-effect profile. Br. J. Anaesth. 103, 38-49 (2009).

129. Leone, S. et al. The analgesic activity of biphalin and its analog AM 94 in rats. Eur. J. Pharmacol. 685, 70-73 (2012).

130. Mollica, A. et al. Antinociceptive profile of potent opioid peptide AM94, a fluorinated analogue of biphalin with non-hydrazine linker. J. Pept. Sci. 19, 233-239 (2013).

131. Aceto, M. D. et al. MDAN-21: A Bivalent Opioid Ligand Containing mu-Agonist and Delta-Antagonist Pharmacophores and Its Effects in Rhesus Monkeys. Int. J. Med. Chem. 2012, 1-6 (2012).

132. Salvadori, S. et al. A new opioid designed multiple ligand derived from the micro opioid agonist endomorphin-2 and the delta opioid antagonist pharmacophore Dmt-Tic. Bioorg. Med. Chem. 15, 6876-81 (2007).

133. Bird, M. F. et al. Development and characterisation of novel fentanyl-delta opioid receptor antagonist based bivalent ligands. Br. J. Anaesth. 114, 646-656 (2015).

134. Bird, M. F. et al. Characterisation of the novel mixed Mu-NOP peptide ligand dermorphin-N/OFQ (DeNo). PLoS One 11, 1-22 (2016).

135. Zaveri, N. T., Jiang, F., Olsen, C., Polgar, W. E. \& Toll, L. Designing bifunctional NOP receptor-mu opioid receptor ligands from NOP receptor-selective scaffolds. Part I. Bioorg. Med. Chem. Lett. 23, 3308-3313 (2013).

136. Hanlon, K. E. et al. Novel peptide ligands with dual acting pharmacophores designed for the pathophysiology of neuropathic pain. Brain Res. 1395, 1-11 (2011).

137. Lipkowski, A. W. \& Misterek, K. Bifunctional pharmacophores. Biological activities of the peptide analog containing both casomorphine-like and substance $\mathrm{P}$ antagonistlike active elements. Pol. J. Pharmacol. Pharm. 44, 25-32

138. Faris, P. L., Komisaruk, B. R., Watkins, L. R. \& Mayer, D. J. Evidence for the neuropeptide cholecystokinin as an antagonist of opiate analgesia. Science 219, 310-2 (1983).

139. Yamamoto, T. et al. Discovery of a potent and efficacious peptide derivative for $\delta / \mu$ opioid agonist/neurokinin 1 antagonist activity with a 2',6'-dimethyl-L-tyrosine: in vitro, in vivo, and NMR-based structural studies. J. Med. Chem. 54, 2029-38 (2011).

140. Ballet, S. et al. Design of Novel Neurokinin 1 Receptor Antagonists Based on 
Conformationally Constrained Aromatic Amino Acids and Discovery of a Potent Chimeric Opioid Agonist-Neurokinin 1 Receptor Antagonist. J. Med. Chem. 54, 24672476 (2011).

141. Kleczkowska, P. et al. PK20, a new opioid-neurotensin hybrid peptide that exhibits central and peripheral antinociceptive effects. Mol. Pain 6, 86 (2010).

142. Bonney, I. M., Foran, S. E., Marchand, J. E., Lipkowski, A. W. \& Carr, D. B. Spinal antinociceptive effects of AA501, a novel chimeric peptide with opioid receptor agonist and tachykinin receptor antagonist moieties. Eur. J. Pharmacol. 488, 91-99 (2004).

143. Lutfy, K. \& Cowan, A. Buprenorphine: a unique drug with complex pharmacology. Curr. Neuropharmacol. 2, 395-402 (2004).

144. Kress, H. G. Clinical update on the pharmacology, efficacy and safety of transdermal buprenorphine. Eur. J. Pain 13, 219-230 (2009).

145. Robinson, S. E. Buprenorphine: an analgesic with an expanding role in the treatment of opioid addiction. CNS Drug Rev. 8, 377-90 (2002).

146. Ruiz, P., Strain, E. C. \& Lowinson, J. H. Lowinson and Ruiz's substance abuse : a comprehensive textbook. (Wolters Kluwer Health/Lippincott Williams \& Wilkins, 2011).

147. Buprenorphine, Buprenorphine Hydrochloride Monograph for Professionals Drugs.com. Available at: https://www.drugs.com/monograph/buprenorphinebuprenorphine-hydrochloride.html. (Accessed: 3rd March 2019)

148. Ciccocioppo, R. et al. Buprenorphine reduces alcohol drinking through activation of the nociceptin/orphanin FQ-NOP receptor system. Biol. Psychiatry 61, 4-12 (2007).

149. Linz, K. et al. Cebranopadol: A Novel Potent Analgesic Nociceptin/Orphanin FQ Peptide and Opioid Receptor Agonist. J. Pharmacol. Exp. Ther. 349, 535-548 (2014).

150. Sałat, K., Furgała, A. \& Sałat, R. Evaluation of cebranopadol, a dually acting nociceptin/orphanin FQ and opioid receptor agonist in mouse models of acute, tonic, and chemotherapy-induced neuropathic pain. Inflammopharmacology 26, 361-374 (2018).

151. Linz, K., Schröder, W., Frosch, S. \& Christoph, T. Opioid-type Respiratory Depressant Side Effects of Cebranopadol in Rats Are Limited by Its Nociceptin/Orphanin FQ Peptide Receptor Agonist Activity. Anesthesiology 126, 708-715 (2017).

152. Lambert, D. G., Bird, M. F. \& Rowbotham, D. J. Cebranopadol: a first in-class example of a nociceptin/orphanin FQ receptor and opioid receptor agonist. $B r . J$. Anaesth. 114, 364-366 (2015).

153. Günther, T. et al. Targeting multiple opioid receptors - improved analgesics with reduced side effects? Br. J. Pharmacol. 175, 2857-2868 (2018).

154. Cebranopadol Efficacy and Safety in Diabetic Patients Suffering From Chronic Pain Caused by Damage to the Nerves - Full Text View - ClinicalTrials.gov. Available at: https://clinicaltrials.gov/ct2/show/NCT01939366. (Accessed: 19th February 2019) 
155. CORAL - Cebranopadol Versus Morphine Prolonged-release in Patients With Chronic Moderate to Severe Pain Related to Cancer - Full Text View - ClinicalTrials.gov. Available at: https://clinicaltrials.gov/ct2/show/study/NCT01964378. (Accessed: 19th February 2019)

156. Eerdekens, M.-H. et al. Cancer-related chronic pain: Investigation of the novel analgesic drug candidate cebranopadol in a randomized, double-blind, noninferiority trial. Eur. J. Pain 23, 577-588 (2019).

157. Ding, H. et al. A bifunctional nociceptin and mu opioid receptor agonist is analgesic without opioid side effects in nonhuman primates. Sci. Transl. Med. 10, eaar3483 (2018).

158. Guerrieri, E., Mallareddy, J. R., Tóth, G., Schmidhammer, H. \& Spetea, M. Synthesis and Pharmacological Evaluation of $\left[{ }^{3} \mathrm{H}\right] \mathrm{HS} 665$, a Novel, Highly Selective Radioligand for the Kappa Opioid Receptor. ACS Chem. Neurosci. 6, 456-463 (2015).

159. Ligeti, M. et al. Synthesis and biological studies of nociceptin derivatives containing the DTPA chelating group for further labeling with therapeutic radionuclides. Peptides 26, 1159-1166 (2005).

160. Kocsis, L. et al. Nociceptin antagonism: probing the receptor by $\mathrm{N}$-acetyl oligopeptides. Regul. Pept. 122, 199-207 (2004).

161. Benyhe, S., Farkas, J., Tóth, G. \& Wollemann, M. Met5-enkephalin-Arg6-Phe7, an endogenous neuropeptide, binds to multiple opioid and nonopioid sites in rat brain. $J$. Neurosci. Res. 48, 249-58 (1997).

162. Zukin, R. S., Eghbali, M., Olive, D., Unterwald, E. M. \& Tempel, A. Characterization and visualization of rat and guinea pig brain kappa opioid receptors: evidence for kappa 1 and kappa 2 opioid receptors. Proc. Natl. Acad. Sci. 85, 4061-4065 (1988).

163. Mansour, A., Khachaturian, H., Lewis, M. E., Akil, H. \& Watson, S. J. Anatomy of CNS opioid receptors. Trends Neurosci. 11, 308-314 (1988).

164. Traynor, J. R. \& Nahorski, S. R. Modulation by mu-opioid agonists of guanosine-5'-O(3-[35S]thio)triphosphate binding to membranes from human neuroblastoma SH-SY5Y cells. Mol. Pharmacol. 47, 848-54 (1995).

165. Rónai, A. Z., Gráf, L., Székely, J. I., Dunai-Kovács, Z. \& Bajusz, S. Differential behaviour of LPH-(61-91)-peptide in different model systems: Comparison of the opioid activities of LPH-(61-91)-peptide and its fragments. FEBS Lett. 74, 182-184 (1977).

166. Leslie, F. M. Methods used for the study of opioid receptors. Pharmacol. Rev. 39, 197249 (1987).

167. Stephenson, R. P. A MODIFICATION OF RECEPTOR THEORY. J. Pharmacol (1956).

168. Kosterlitz, H. W. \& Watt, A. J. KINETIC PARAMETERS OF NARCOTIC AGONISTS AND ANTAGONISTS, WITH PARTICULAR REFERENCE TO NALLYLNOROXYMORPHONE (NALOXONE). Br. J. Pharmac. Chemother 33, (1968).

169. William H.Prusoff, Y.-C. Relationship between the inhibition constant (KI) and the 
concentration of inhibitor which causes 50 per cent inhibition (I50) of an enzymatic reaction. Biochem. Pharmacol. 22, 3099-3108 (1973).

170. Kosterlitz, H. W., Paterson, S. J. \& Morley, J. S. Characterization of Opioid Receptors in Nervous Tissue [and Discussion]. Proc. R. Soc. B Biol. Sci. 210, 113-122 (1980).

171. Gyires, K., Rónai, A. Z., Tóth, G., Darula, Z. \& Fürst, S. Analysis of the role of delta opioid receptors in gastroprotection in the rat. Life Sci. 60, 1337-1347 (1997).

172. Makó, E. \& Rónai, A. Z. Characterization of kappa and delta opioid receptors in isolated organs by using type/subtype selective agonists and antagonists. Med. Sci. Monit. 7, 350-6

173. Portoghese, P. S. Bivalent ligands and the message-address concept in the design of selective opioid receptor antagonists. Trends Pharmacol. Sci. 10, 230-235 (1989).

174. Tancredi, T., Saviano, G., Temussi, P., Picone, D. \& Crescenzi, O. Solution structure of human $\beta$-endorphin in helicogenic solvents: an NMR study. J. Pept. Sci. 5, 410-422 (2002).

175. Schwyzer, R. Molecular mechanism of opioid receptor selection. Biochemistry 25, 6335-6342 (1986).

176. Dooley, C. T. et al. Binding and in vitro activities of peptides with high affinity for the nociceptin/orphanin FQ receptor, ORL1. J. Pharmacol. Exp. Ther. 283, 735-41 (1997).

177. Agnes, R. S. et al. Structure-activity relationships of bifunctional peptides based on overlapping pharmacophores at opioid and cholecystokinin receptors. J. Med. Chem. 49, 2868-75 (2006).

178. Marinova, Z. et al. Translocation of Dynorphin Neuropeptides across the Plasma Membrane. J. Biol. Chem. 280, 26360-26370 (2005).

179. Marinova, Z. OPIOID AND NON-OPIOID ACTIVITIES OF THE DYNORPHINS. (2006).

180. Kakidani, H. et al. Cloning and sequence analysis of cDNA for porcine beta-neoendorphin/dynorphin precursor. Nature 298, 245-9 (1982).

181. Paterlini, G., Portoghese, P. S. \& Ferguson, D. M. Molecular simulation of dynorphin A-(1-10) binding to extracellular loop 2 of the kappa-opioid receptor. A model for receptor activation. J. Med. Chem. 40, 3254-62 (1997).

182. Li, J., Nishimura, H., Matsushima, A. \& Shimohigashi, Y. N-methylthioacetylation of RYYRIK-NH2 with enhanced specific binding affinity and high antagonist activity for nociceptin ORL1 receptor. Bioorg. Med. Chem. 22, 5721-6 (2014).

183. Lord, J. A. H., Waterfield, A. A., Hughes, J. \& Kosterlitz, H. W. Endogenous opioid peptides: multiple agonists and receptors. Nature 267, 495-499 (1977).

184. Al-Khrasani, M. et al. Receptor constants for endomorphin-1 and endomorphin-1-ol indicate differences in efficacy and receptor occupancy. Eur. J. Pharmacol. 421, 61-7 (2001).

185. Rónai, A. Z., Berzétei, I. \& Bajusz, S. Differentiation between opioid peptides by naltrexone. Eur. J. Pharmacol. 45, 393-394 (1977). 
186. Rónai, A. Z., Székely, J. I., Berzétei, I., Miglécz, E. \& Bajusz, S. Tetrapeptide-amide analogues of enkephalin: The role of $\mathrm{C}$-terminus in determining the character of opioid activity. Biochem. Biophys. Res. Commun. 91, 1239-1249 (1979).

187. Gündüz, Ö. et al. In vitro Binding and Functional Studies of Ac-RYYRIK-ol and Its Derivatives, Novel Partial Agonists of the Nociceptin/Orphanin F/Q Receptor.

Neurosignals 15, 91-101 (2006). 
Off-prints of thesis related publications:

\section{I.}

Erdei AI, Borbely A, Magyar A, Taricska N, Perczel A, Zsiros O, Garab G, Szucs E, Otvos F, Zador F, Balogh M, Al-Khrasani M, Benyhe S. Biochemical and pharmacological characterization of three opioid-nociceptin hybrid peptide ligands reveals substantially differing modes of their actions. PEPTIDES 99: pp. 205-216. (2018) 
Research article

\title{
Biochemical and pharmacological characterization of three opioid- nociceptin hybrid peptide ligands reveals substantially differing modes of their actions
}

\author{
Anna I. Erdei ${ }^{\mathrm{a}}$, Adina Borbély ${ }^{\mathrm{b}}$, Anna Magyar ${ }^{\mathrm{b}}$, Nóra Taricska ${ }^{\mathrm{c}}$, András Perczel ${ }^{\mathrm{c}, \mathrm{d}}$, Ottó Zsíros ${ }^{\mathrm{e}}$, \\ Győző Garab ${ }^{\mathrm{e}}$, Edina Szú́cs ${ }^{\mathrm{a}}$, Ferenc Ötvös ${ }^{\mathrm{a}}$, Ferenc Zádor ${ }^{\mathrm{a}}$, Mihály Balogh ${ }^{\mathrm{f}}$, \\ Mahmoud Al-Khrasani ${ }^{\mathrm{f}}$, Sándor Benyhe ${ }^{\mathrm{a}, *}$ \\ a Institute of Biochemistry, Biological Research Center, Hungarian Academy of Sciences, H-6726, Szeged, Temesvári krt. 62., Hungary \\ b MTA-ELTE Research Group of Peptide Chemistry, Hungarian Academy of Sciences, Eötvös Loránd University, H-1117, Budapest, Pázmány Péter sétány 1/A, Hungary \\ c Laboratory of Structural Chemistry and Biology, Institute of Chemistry, Eötvös Loránd University, Pázmány P. sétány 1/A, Budapest, H-1117, Hungary \\ d MTA-ELTE Protein Modelling Research Group, Institute of Chemistry, Hungarian Academy of Sciences, Eötvös Loránd University, H-1117, Budapest, Pázmány Péter \\ sétány $1 /$ A, Hungary \\ e Institute of Plant Biology, Biological Research Center, Hungarian Academy of Sciences, H-6726, Szeged, Temesvári krt. 62., Hungary \\ ${ }^{\mathrm{f}}$ Department of Pharmacology and Pharmacotherapy, Semmelweis University, H-1445, Budapest, Nagyvárad tér 4., Hungary
}

\section{A R T I C L E I N F O}

\section{Keywords:}

Radioligand binding

Mouse vas deferens

Opioid receptors

NOP receptor

Nociception

Bivalent ligands

\begin{abstract}
A B S T R A C T
In an attempt to design opioid-nociceptin hybrid peptides, three novel bivalent ligands, H-YGGFGGGRYYRIK$\mathrm{NH}_{2}, \mathrm{H}$-YGGFRYYRIK-NH $\mathrm{H}_{2}$ and Ac-RYYRIKGGGYGGFL-OH were synthesized and studied by biochemical, pharmacological, biophysical and molecular modelling tools. These chimeric molecules consist of YGGF sequence, a crucial motif in the N-terminus of natural opioid peptides, and Ac-RYYRIK-NH $\mathrm{N}_{2}$, which was isolated from a combinatorial peptide library as an antagonist or partial agonist that inhibits the biological activity of the endogenously occurring heptadecapeptide nociceptin. Solution structures for the peptides were studied by analysing their circular dichroism spectra. Receptor binding affinities were measured by equilibrium competition experiments using four highly selective radioligands. G-protein activating properties of the multitarget peptides were estimated in $\left[{ }^{35} \mathrm{~S}\right] \mathrm{GTP} \gamma \mathrm{S}$ binding tests. The three compounds were also measured in electrically stimulated mouse vas deferens (MVD) bioassay. H-YGGFGGGRYYRIK-NH $\mathrm{N}_{2}$ (BA55), carrying N-terminal opioid and C-terminal nociceptin-like sequences interconnected with GGG tripeptide spacer displayed a tendency of having either unordered or $\beta$-sheet structures, was moderately potent in MVD and possessed a NOP/KOP receptor preference. A similar peptide without spacer H-YGGFRYYRIK- $\mathrm{NH}_{2}$ (BA62) exhibited the weakest effect in MVD, more $\alpha$-helical periodicity was present in its structure and it exhibited the most efficacious agonist actions in the G-protein stimulation assays. The third hybrid peptide Ac-RYYRIKGGGYGGFL-OH (BA61) unexpectedly displayed opioid receptor affinities, because the opioid message motif is hidden within the C-terminus. The designed chimeric peptide ligands presented in this study accommodate well into a group of multitarget opioid compounds that include opioid-non-opioid peptide dimer analogues, dual non-peptide dimers and mixed peptide- non-peptide bifunctional ligands.
\end{abstract}

\section{Introduction}

G protein-coupled receptors (GPCRs) are ancestrally related membrane proteins on various cells that mediate the physiological and pharmacological effect of most drugs, hormones and neurotransmitters. GPCRs are the largest family of proteins encoded in the human genome. One of the most important types of GPCRs is the opioid receptors [1-6]. Opioid family receptors consist of four closely related cell surface proteins expressed in all vertebrate animals examined to date. The three classical types of opioid receptors shown unequivocally to mediate analgesia in animal models and in humans are the $m u$ - (MOP), delta(DOP), and kappa- (KOP) opioid receptor proteins. The fourth and most recent member of the opioid receptor family described is the nociceptin or orphanin FQ receptor also called as NOP receptor or ORL-1 (opioid receptor like) receptor $[7,8]$. The role of NOP receptor and its ligands in mediating analgesia is not as clear, with both analgesic and

\footnotetext{
* Corresponding author at: Institute of Biochemistry, Biological Research Center, Hungarian Academy of Sciences, H-6726 Szeged, Temesvári krt. 62. , Hungary.

E-mail address: benyhe@brc.hu (S. Benyhe).
} 


\section{hyperalgesic effects reported.}

Natural ligands for the opioid receptor subfamily are endogenous opioid peptides. They include Met- and Leu-enkephalin [9], $\beta$-endorphin [10], dynorphin A [11] and nociceptin or orphanin FQ [7,8]. Opioid peptides are easy and frequent targets for chemical modifications, so it is not surprising that a huge amount of synthetic opioid peptides have been reported with various structural modifications for reviews see [12-14] and [15-18]. Hybrid or bifunctional peptide or non-peptide ligands developed recently, bearing two pharmacophores, represent novel biochemical tools in investigating GPCRs and their interacting complexes. The pioneer synthetic bifunctional opioid peptide was a double enkephalin later named biphalin [19]. Biphalin (Tyr-DAla-Gly-Phe-NH-NH $<-$ Phe $<-$ Gly $<-$ d-Ala $<-$ Tyr ) is an opioid octapeptide with a dimeric structure based on two identical pharmacophore portions, derived from enkephalins, joined "tail to tail" by a hydrazide bridge. Numerous structure-activity relationship studies (SAR) were performed in order to understand the elements responsible for the high activity of biphalin [20]. Beside biphalin, a number of other chimeric opioid peptides linked by spacer have been studied so far. Opioid peptides have often been combined with other bioactive neurotransmitters and peptide hormones that are involved in pain perception, e.g. substance P, neurotensin, cholecystokinin, cannabinoids, neuromedin ligands, etc. [21]. Such novel peptide chimeras (also called designed multiple ligands or twin or hybrid drugs), may interact independently with their respective receptor proteins.

Here we describe and characterize three novel hybrid opioid peptides using in vitro displacement binding and functional $\left[{ }^{35} \mathrm{~S}\right] \mathrm{GTP} \gamma \mathrm{S}$ binding assay as well as mouse vas deferens bioassay. These bivalent ligands (BA55 and BA62) are composed either of the minimum opioid tetrapeptide structure (Tyr-Gly-Gly-Phe; YGGF) or (Tyr-Gly-Gly-PheLeu; YGGFL) targeting the opioid receptors, and a NOP receptor recognizing synthetic sequence Ac-Arg-Tyr-Tyr-Arg-Ile-Lys- $\mathrm{NH}_{2}$ (AcRYYRIK- $\mathrm{NH}_{2}$ ) isolated originally from combinatorial chemical libraries [22]. Ac-RYYRIK- $\mathrm{NH}_{2}$ and its related hexapeptides were reported to behave as partial agonists [22], therefore they are capable of antagonizing NOP receptor selective pure agonist ligands [23-27]. The related peptide fragments were either fused directly or connected via an arbitrary given short tripeptide spacer composed of three glycine residues (GGG). The structures of the three hybrid peptides are H-YGGFGGGRYYRIK-NH ${ }_{2}, \quad$ H-YGGFRYYRIK-NH ${ }_{2}, \quad$ Ac-RYYRIKGGGYGGFL$\mathrm{OH}$. Combining the MOP/DOP/KOP receptor agonist structure with the NOP receptor partial agonist/antagonist sequence Ac-RYYRIK- $\mathrm{NH}_{2}$ would result in effective bivalent compounds targeting the individual opioid receptors and perhaps their interacting complexes, e.g., MOP/ NOP or DOP/NOP receptor heterodimers.

\section{Materials and methods}

\subsection{Chemicals}

All amino acid derivatives, resins (Rink-amide MBHA, 2-chlorotrityl resin) and coupling agents were purchased from IRIS Biotech $\mathrm{GmbH}$ (Marktredwitz, Germany), Reanal (Budapest, Hungary) or Fluka (Buchs, Switzerland). Solvents for synthesis and HPLC were from Molar Chemicals (Budapest, Hungary) or Merck Kft (Budapest, Hungary). Tris$\mathrm{HCl}, \mathrm{MgCl}_{2} \times 6 \mathrm{H}_{2} \mathrm{O}, \mathrm{EGTA}, \mathrm{NaCl}$, GDP, the GTP analogue GTP $\gamma$, Bovine serum albumin (BSA), the [d-Ala2, d-Leu5] enkephalin (DADLE) and U-69,593 were purchased from Sigma-Aldrich (Budapest, Hungary). YGGF, Leu-enkephalin and nociceptin was obtained from Bachem Holding AG (Bubendorf, Switzerland). The Tyr-D-Ala-Gly(NMe)Phe-Gly-ol (DAMGO), the Ile ${ }^{5,6}$-deltorphin II (IleDelt II) were synthesized in the Laboratory of Chemical Biology group of the Biological Research Center (BRC, Szeged, Hungary) and the AcRYYRIK-NH2 was synthesized in the Research Group of Peptide Chemistry of MTA-ELTE, Budapest. The U50,488H was obtained from the Upjohn Company, (Kalamazoo, MI, USA) and the ethylketocyclazocine (EKC) was purchased from Sterling Winthrop (Rensselaer, NY, USA). The naltrindole, nor-BNI, and JTC-801 were purchased from Tocris Bioscience (Bristol, UK). The naloxone was kindly provided by the company Endo Laboratories DuPont de Nemours (Wilmington, DE, USA) and the cyprodime was a gift from Prof. Helmut Schmidhammer, Innsbruck University, Innsbuck, Austria. Ligands were dissolved in water and were stored in $1 \mathrm{mM}$ stock solution at $-20^{\circ} \mathrm{C}$. The radiolabelled GTP analogue, $\left[{ }^{35} \mathrm{~S}\right] \mathrm{GTP} \gamma \mathrm{S}$ (specific activity: 1000 $\mathrm{Ci} / \mathrm{mmol}$ ) was purchased from Hartmann Analytic (Braunschweig, Germany). [ $\left.{ }^{3} \mathrm{H}\right]$ DAMGO (specific activity: $38.8 \mathrm{Ci} / \mathrm{mmol}$ ), $\left[{ }^{3} \mathrm{H}\right]$ IleDelt II (specific activity: $19.6 \mathrm{Ci} / \mathrm{mmol}$ ) and $\left[{ }^{3} \mathrm{H}\right] \mathrm{HS} 665$ (specific activity: 13.1 $\mathrm{Ci} / \mathrm{mmol}$ ) were radiolabelled by the Laboratory of Chemical Biology group in BRC (Szeged, Hungary) and were characterized previously. $\left[{ }^{3} \mathrm{H}\right] \mathrm{U}-69,593$ (specific activity: $43.6 \mathrm{Ci} / \mathrm{mmol}$ ) and $\left[{ }^{3} \mathrm{H}\right]$ Nociceptin (specific activity: $115.5 \mathrm{Ci} / \mathrm{mmol}$ ) were purchased from PerkinElmer (Boston, USA). The UltimaGoldTM MV aqueous scintillation cocktail was purchased from PerkinElmer (Boston, USA).

\subsection{Circular dichroism (CD) spectroscopy}

Far-UV CD spectra were recorded at $25{ }^{\circ} \mathrm{C}$ temperature on Jasco J810 spectropolarimeter on the peptide. The $\mathrm{CD}$ spectra were measured at between 260 and $185 \mathrm{~nm}$ with an optical pathlength of $1 \mathrm{~mm}$, the peptide concentration was $\sim 0.1 \mathrm{mg} / \mathrm{ml}$ in Milli-Q water. The bandwidth was $2 \mathrm{~nm}$ and data pitch $1.0 \mathrm{~nm}$, the scan speed was set to $100 \mathrm{~nm} / \mathrm{min}$ and the integration time was $1 \mathrm{~s} .10$ spectra were accumulated and plotted. Far UV spectra were analized by CDSSTR method (dichroweb.cryst.bbk.ac.uk/html/home.shtml).

Near-UV range: Typical spectral accumulation parameters were the scanning speed $50 \mathrm{~nm} / \mathrm{min}$ with $1 \mathrm{~nm}$ bandwidth and the $0.2 \mathrm{~nm}$ step resolution over wavelength range $240-325 \mathrm{~nm}$ with five scans averaged for each spectrum. The temperature at the cuvette was controlled by Peltier-type heating system. The raw ellipticity data were converted into molar ellipticity $\left([\theta] / \mathrm{deg}^{*} \mathrm{~cm} 2 * \mathrm{dmol}-1\right)$ for the near-UV region.

\subsection{Molecular dynamics calculations}

The conformers were generated by simulated annealing and energy minimization method. An initial unrestrained molecular dynamics simulation was performed at $1000 \mathrm{~K}$ to override the conformational barriers. The trajectory was sampled every picoseconds and the resulting snapshots were annealed to $50 \mathrm{~K}$ for two picoseconds and then energy minimized by RMS gradient convergence criterion of 0.001 . Molecular modelling was performed by the Tinker program package v. 6.3.3 (Software Tools for Molecular Design Washington University Medical School, USA). All molecular dynamics steps were performed using the amber99 force field and GBSA implicit solvent environment. Investigation of the secondary structure of the conformers was performed by the Stride program [28].

\subsection{Animals}

In experiments designed for receptor binding assay: male and female Wistar rats (250-300 g body weight) and male guinea pigs ( $\sim 700 \mathrm{~g}$ body weight, LAL/HA/BR strain) were used. Rats were housed in the local animal house of BRC (Szeged, Hungary), while guinea pigs were housed in LAB-ÁLL Bt. (Budapest, Hungary). For MVD experiments NMRI mice (35-45 g) were used. Mice were purchased from Toxicoop (Budapest, Hungary) and they were housed in the local animal house of the Department of Pharmacology and Pharmacotherapy, Semmelweis University (Budapest, Hungary) in group of 5 animals/ cage.

Animals were kept in a temperature controlled room $\left(21-24{ }^{\circ} \mathrm{C}\right)$ under a 12:12 light and dark cycle, allowed free access to tap water and standard rodent food until the time of sacrifice. The animals were handled humanely, in complete accordance with the European directive 
2010/63/EU on the protection of animals used for scientific purposes and the Hungarian Act for the Protection of Animals in Research (XXVIII.tv. 32.§). Both the number of rats and their suffering were minimized throughout our experiments.

\subsection{Peptide synthesis}

The peptides were synthesized by solid phase peptide synthesis method using Fmoc strategy on Rink-amide MBHA (HYGGFGGGRYYRIK-NH $\mathrm{N}_{2}, \quad \mathrm{H}$-YGGFRYYRIK- $\mathrm{NH}_{2}$ ) or on 2-chlorotrityl resin (Ac-RYYRIKGGGYGGFL-OH). Amino acids were coupled as Fmoc derivatives by the DIC/HOBt coupling method in DMF. After removal of the last Fmoc group, the N-terminus was acetylated by acetic anhydride and DIEA. The crude products were purified by semipreparative RPHPLC and the purified compounds were characterized by analytical RPHPLC and ESI-ion trap mass spectrometry.

\subsection{Rat and guinea pig brain membrane homogenate preparation for binding assays}

Animals were decapitated and rat or guinea pig brains were quickly removed. The brains were prepared according to a method previously described [29] and partly used for binding experiments and partly were further prepared for the $\left[{ }^{35} \mathrm{~S}\right] \mathrm{GTP} \gamma \mathrm{S}$ binding experiments according to [30]. Briefly, the full brain (without cerebellum) were homogenized, centrifuged in ice-cold $50 \mathrm{mM}$ Tris-HCl (pH 7.4) buffer and incubated at $37^{\circ} \mathrm{C}$ for $30 \mathrm{~min}$ in a shaking water-bath for details see [31]. After incubation the centrifugation was repeated as described before and the final pellet was suspended in $50 \mathrm{mM}$ Tris- $\mathrm{HCl} \mathrm{pH} 7.4$ buffer containing $0.32 \mathrm{M}$ sucrose. For the $\left[{ }^{35} \mathrm{~S}\right] \mathrm{GTP} \gamma \mathrm{S}$ binding experiments the final pellet of rat or guinea pig brain membrane homogenate was suspended in icecold TEM ( $50 \mathrm{mM}$ Tris- $\mathrm{HCl}, 1 \mathrm{mM}$ EGTA, $3 \mathrm{mM} \mathrm{MgCl} 2$ ) buffer so that the desired protein concentration for the assay $(\sim 10 \mu \mathrm{g} / \mathrm{ml})$ could be achieved. The proteins were stored at $-80{ }^{\circ} \mathrm{C}$ until future use.

\subsection{Displacement binding assay}

In competition binding experiments the affinity of an unlabelled compound is analysed by measuring radioligand specific binding in the presence of increasing concentrations of the unlabelled compound in question. Aliquots of frozen rat brain membrane homogenates were suspended in $50 \mathrm{mM}$ Tris- $\mathrm{HCl}$ buffer ( $\mathrm{pH} \mathrm{7.4).} \mathrm{Membrane} \mathrm{fractions}$ containing $0.3-0.5 \mathrm{mg} / \mathrm{ml}$ of protein were incubated with crescent concentrations $\left(10^{-10}-10^{-5} \mathrm{M}\right)$ of the unlabelled tested ligands and $1 \mathrm{nM}$ of the radioligands. Incubation conditions for rat brain homogenates were as follows: for $\left[{ }^{3} \mathrm{H}\right]$ DAMGO and $\left[{ }^{3} \mathrm{H}\right]$ IleDelt II $35{ }^{\circ} \mathrm{C}$ for $45 \mathrm{~min}$, for $\left[{ }^{3} \mathrm{H}\right] \mathrm{U}-69,59324{ }^{\circ} \mathrm{C}$ for $45 \mathrm{~min}$, for $\left[{ }^{3} \mathrm{H}\right]$ Nociceptin $30{ }^{\circ} \mathrm{C}$ for $30 \mathrm{~min}$. In case of $\left[{ }^{3} \mathrm{H}\right] \mathrm{U}-69,593$ in guinea pig brain membrane homogenates (guinea pig brain has significantly more kappa receptors than rat brain). Additionally, unlabelled IleDelt II, U-69,593, DAMGO and nociceptin were also incubated together with their labelled counterparts in increasing concentrations $\left(10^{-10}-10^{-5} \mathrm{M}\right)$ for control. For experiments performed with $\left[{ }^{3} \mathrm{H}\right]$ Nociceptin the incubation mixture also contained $50 \mathrm{mM}$ Tris/HCl, $2.5 \mathrm{mM}$ EGTA, $5 \mathrm{mM} \mathrm{MgCl}_{2}$ and $0.5 \mathrm{mg} / \mathrm{ml}$ fatty acid-free BSA ( $\mathrm{pH} 7.4)$. The level of non-specific binding was determined in the presence of $10 \mathrm{mM}$ unlabelled naloxone, U-69,593, nociceptin or naltrindole, while total binding was determined in the absence of cold compounds. The reaction was terminated by rapid filtration under vacuum (Brandel M24R Cell Harvester; Brandel Harvesters, Gaithersburg, MD), and washed three times with $5 \mathrm{ml}$ ice-cold $50 \mathrm{mM}$ Tris-HCl or $50 \mathrm{mM}$ Tris/HCl, $2.5 \mathrm{mM}$ EGTA, $5 \mathrm{mM}$ $\mathrm{MgCl}_{2}, 0.5 \% \mathrm{BSA}\left(\mathrm{pH} 7.4\right.$ ) in case of $\left[{ }^{3} \mathrm{H}\right]$ Nociceptin. The filtration was accomplished through Whatman GF/C $\left(\left[{ }^{3} \mathrm{H}\right]\right.$ DAMGO, $\left[{ }^{3} \mathrm{H}\right]$ IleDelt II) or GF/B ( $\left[{ }^{3} \mathrm{H}\right] \mathrm{U}-69593$ and $\left[{ }^{3} \mathrm{H}\right]$ Nociceptin) glass fibre filters (GE Healthcare, Little Chalfont, UK). The radioactivity was detected in UltimaGold MV aqueous scintillation cocktail (Perkin Elmer, Waltham,
MA) with Packard Tricarb 2300TR LSC spectrometer. The competition binding assays were performed in duplicates and repeated at least three times.

\subsection{Functional $\left[{ }^{35} S\right] G T P \gamma S$ binding experiments}

The functional $\left[{ }^{35} \mathrm{~S}\right] \mathrm{GTP} \gamma \mathrm{S}$ binding experiments were performed as previously described by [32], with slight modifications. Briefly the rat brain membrane fractions ( $\sim 10 \mu \mathrm{g}$ protein per sample) were incubated at $30{ }^{\circ} \mathrm{C}$ for $60 \mathrm{~min}$ in Tris-EGTA buffer (pH 7.4). The buffer was composed of $50 \mathrm{mM}$ Tris-HCl, $1 \mathrm{mM}$ EGTA, $3 \mathrm{mM} \mathrm{MgCl}_{2}, 100 \mathrm{mM} \mathrm{NaCl}$, $30 \mu \mathrm{M}$ GDP, containing $20 \mathrm{MBq} / 0.05 \mathrm{~cm}^{3}\left[{ }^{35} \mathrm{~S}\right] \mathrm{GTP} \gamma \mathrm{S}(0.05 \mathrm{nM})$ and increasing concentrations $\left(10^{-10}-10^{-5} \mathrm{M}\right)$ of the tested compounds in the presence or absence of $10 \mu \mathrm{M}$ receptor specific antagonist (cyprodime, naltrindole or norbinaltorphimine). The final volume was $1 \mathrm{ml}$. Total binding (T) was measured in the absence of the test compounds, while non-specific binding (NS) was determined in the presence of $10 \mu \mathrm{M}$ unlabelled GTP $\gamma \mathrm{S}$ and subtracted from the total binding value, to determine the specific binding. Throughout this paper, G-protein activation is given as percentage over the specific $\left[{ }^{35} \mathrm{~S}\right] \mathrm{GTP} \gamma \mathrm{S}$ binding obtained in the absence of receptor ligands (basal activity). The difference of total binding (T) and non-specific binding (NS) represents the basal activity and was defined as $100 \%$. After incubation, bound and unbound $\left[{ }^{35} \mathrm{~S}\right] \mathrm{GTP} \gamma \mathrm{S}$ were separated by vacuum filtration through Whatman GF/B glass fiber filters with a Brandel M24R Cell harvester.

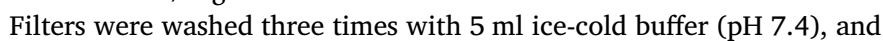
the radioactivity of the filters was measured in UltimaGOLD ${ }^{\mathrm{TM}}$ (Perkin Elmer) scintillation cocktail with a Packard TriCarb 2300TR counter. The experiments were performed in triplicates and repeated at least three times.

\subsection{Mouse vas deferens (MVD) bioassay}

Vasa deferentia from NMRI mice (35-45 g) were prepared as described previously [33]). Briefly, vasa deferentia (a single organ/bath) were mounted between two electrodes under an initial tension $0.1 \mathrm{~g}$ in $\mathrm{Mg}^{2+}$ free Krebs solution aerated with carbogen $\left(\mathrm{O}_{2}: \mathrm{CO}_{2}=95: 5\right)$ at $31{ }^{\circ} \mathrm{C}$. Field electrical stimulation (upper ring, lower straight wire electrode arrangement) was used. The stimulation parameters were as follows: field stimulation, pairs (100 ms pulse distance) of rectangular impulses ( $1 \mathrm{~ms}$ pulse width, $9 \mathrm{~V} / \mathrm{cm}$ i.e. supramaximal intensity) were repeated by $10 \mathrm{~s}$. The muscle contractions were monitored by computer, using a data recording and analysis system (LabChart 5, ADInstruments Pty LTD, Australia).

\subsection{Experimental paradigms of $M V D$}

In the mouse vas deferens experiments, before adding the first dose of agonists, 30-40 min equilibration was used for tissues under stimulation. For all experiments, only one concentration-effect curve for the agonists was constructed per tissue [34] and each of these was constructed in cumulative manner. The drug exposure was less than $2 \mathrm{~min}$, and the administration cycle 12-18 min. Preparations were then washed out and allowed to regain their pre-drug twitch height. Then they were equilibrated for $20 \mathrm{~min}$ with antagonists (naloxone, JTC-801, naltrindole, nor-BNI), and without washing a single concentration of agonist was added. To determine dissociation constants of the antagonist, dose ratio (DR) values were obtained by the single-dose method described [35].

\subsection{Data analysis}

Radioligand binding experiments were performed in duplicate and the $\left[{ }^{35} \mathrm{~S}\right] \mathrm{GTP} \gamma \mathrm{S}$ binding assays were carried out in triplicate. Experimental data were analysed and graphically processed as means \pm S.E.M in the function of the applied ligand concentration 
range in logarithm form. Points were fitted with the professional curve fitting program, GraphPad Prism 6.0 (GraphPad Prism Software Inc., San Diego, CA, USA, www.graphpad.comwww.graphpad.com), using non-linear regression. In the radioligand competition binding assays the 'One-site competition', while in $\left[{ }^{35} \mathrm{~S}\right] \mathrm{GTP} \gamma \mathrm{S}$ binding assays the 'Sigmoid dose-response' equation was applied to determine $\mathrm{IC}_{50}$ and $\mathrm{K}_{\mathrm{i}}$ (unlabelled ligand affinity) and ligand potency $\left(\mathrm{EC}_{50}\right)$ and the maximum $\mathrm{G}$ protein efficacy $\left(\mathrm{E}_{\max }\right)$, respectively. For $\mathrm{IC}_{50}$ and $\mathrm{EC}_{50}$ values standard error is only given in their logarithm form by the curve fitting program due to the data representation. The specific binding of either radiolabelled compound was calculated by the subtraction of non-specific binding from total binding and was given in percentage. The data was normalized to total specific binding, which was settled $100 \%$, which in case of $\left[{ }^{35} \mathrm{~S}\right] \mathrm{GTP} \gamma \mathrm{S}$ also represents the basal activity of the G-protein. In the MVD bioassay, the $50 \%$ effective concentration $\left(\mathrm{EC}_{50}\right)$ and maximal effect (Emax) was determined from the non-linear regression (Hill 4 parameters equation) of individual logarithmic concentration-response curves. The equilibrium dissociation constant of antagonists $\left(\mathrm{K}_{\mathrm{e}}\right)$ was calculated with the single-dose method [35]. Antagonist affinities $\left(\mathrm{K}_{\mathrm{e}}\right.$ values) were calculated as: $\mathrm{K}_{\mathrm{e}}=$ [antagonist concentration]/dose ratio -1 . Experimental data were analysed and graphically represented as means \pm S.E.M with curve fitting program, SigmaPlot 11.0. (Systat Software, San Jose, CA). Differences between two data sets unpaired $t$ test with two-tailed P-value statistical analysis was used, while for three or more data sets one-way ANOVA with Tukey's post hoc test was performed to determine statistical significance. Significance was accepted at the $\mathrm{P}<0.05$ level.

\section{Results}

\subsection{Circular dichroism (CD) spectroscopy}

Three novel hybrid peptides composed of opioid (YGGF) and nociceptin-like (RYYRIK) building blocks were synthesized and studied. A detailed analysis of the different ECD (electron-capture dissociation) spectra of the bivalent peptides provided the following structural information: Table within Fig. 1. shows the relative distributions of secondary structures observed. Spectral data collected at $25^{\circ} \mathrm{C}$ were analysed by CDSSTR method using reference dataset: 3 [36]. Peptide BA55 has been associated with the unordered motive and the turns, while BA61 and BA62 the $\beta$-sheet and $\alpha$-helix motives are dominant, respectively. Due to the aromatic amino acid content of these peptides the near-UV ECD region can also be informative (Fig. 1B, C and D). All three peptides have similar spectral properties at all 3 temperatures recorded: i) a negative band at around $280 \mathrm{~nm}\left(\mathrm{~L}_{\mathrm{b}}\right.$ of Tyr) disappearing at $85^{\circ} \mathrm{C}$ a bit more pronounced for BA61, ii) a positive band at about $260 \mathrm{~nm}$ (most probably $\mathrm{L}_{\mathrm{b}}$ of Phe) and iii) the shoulder of a larger band $\left(248 \mathrm{~nm}\right.$ ) positive at $5{ }^{\circ} \mathrm{C}$ reversed in sign at $85^{\circ} \mathrm{C}$. In summary, the atypical far-UV ECD spectra, with bands strongly influenced by electronic transitions arising from the aromatic residues suggest rather an unstructured polypeptide main chain, which otherwise could have some partial order unrevealed at lower $\mathrm{T}$, completely vanishing at elevated temperature.

\subsection{Molecular dynamics calculations}

The effect of the structure of the peptides on the biological activity on the NOP receptor was related to their secondary structure in solution analysed by both experimental and theoretical methods. Due to the conformational flexibility of peptides, a widely used experimental method to investigate their secondary structure is the electronic circular dichroism (CD) spectroscopy. In silico investigation of flexible peptides can be performed by the conformational analysis of conformer ensembles. Here we analysed ensembles of 50000 energy minimized conformers generated by molecular dynamics (MD) simulation (Fig. 2). The binding activities shown for the NOP receptor can be correlated to the secondary structure patterns of the peptides. The amount of the turns present in the peptides seems to be proportional to the affinity, as in the most active BA61 turns were found in nearly 50\%. Contrary to the turns, the presence of helices in the peptides showed a reverse effect, as the most helical BA62 proved to be inactive on NOP receptor. The percentile ratios and the location of the different secondary structure elements distributed within the conformer ensembles were compared to the experimental results obtained by $\mathrm{CD}$. The percentage of a specific secondary structure was calculated as follows:

100x (sum of the affected resides in the ensemble)/(sum of all residues in the ensemble)

The negligible amount of beta strands in the conformers was in accordance of their absence in the CD spectra. The rank order of the overall amount of turns was the same as obtained by CD. In the case of helices, the helix content of the inactive BA62 was the highest, as expected. Besides the overall amount of the secondary structure elements their location was also investigated. The most abundant beta turn type IV distributed almost uniformly along the peptide chains. beta turn type I, the second highest amount turn type, mostly abounded close to the Nterminal in the most active BA61 but farther from the N-terminal in other two peptides (Figure turns). The distribution of helices in the peptides seems to be related to the RYYRIK segment (Figure helices). However, besides the core RYYRIK segment, the helical character seems to be prune to extend toward the nearby glycine rich regions too.

\subsection{Receptor binding assays and functional $\left[{ }^{35} S\right] G T P \gamma S$ binding experiments}

Heterologous equilibrium competition curves are shown in Fig. 3. and these studies are summarized in Table 1. Each of the three peptides displaced the receptor type-selective radioligands with various affinities. The highest NOP receptor affinity was obtained with BA61 $\left(\mathrm{K}_{\mathrm{i}}\right.$ $16 \mathrm{nM}$, Table 1) confirming that the Ac-RYYRIK- $\mathrm{NH}_{2} \mathrm{~N}$-terminal sequence carries NOP receptor interacting motifs. Most of the curves were accurately fitted by the 'one binding site' model. However, the curve for $\left[{ }^{3} \mathrm{H}\right] \mathrm{DAMGO} / \mathrm{BA} 61$ the 'two site fit' was really perfect with $\mathrm{K}_{\mathrm{i}}$ values of $0.02 \mathrm{nM}$ (high affinity site) and $2.4 \mu \mathrm{M}$ (low affinity site), respectively. The $\mathrm{K}_{\mathrm{i}}$ values of BA61 were 0.9 and $155 \mathrm{nM}$ measured with $\left[{ }^{3} \mathrm{H}\right] \mathrm{U}$ 69,593 suggesting again biphasic interaction in the case of KOP receptor ('two site fit' calculation). Moreover, the displacement curve of this competition was not complete (Fig. 3C panel) with substantial residual binding activity (around 50\%). The apparent high affinities of H-YGGF-OH and BA61 in the KOP receptor assay (Fig. 3C panel) were also accompanied by higher residual binding levels.

Binding selectivity ratios were calculated as quotients of the corresponding $K_{i}$ values (Table 2), while\% relative affinity values (Table 2last column) were calculated according to [37]. BA55 is characterized by higher KOP/NOP receptor preference, although sequence predictions suggested rather a MOP/DOP receptor selectivity for BA55. BA61 peptide exhibits NOP receptor preference (75\%), while the characteristic target for the peptide BA62 is the DOP receptor (66\%).

Agonist induced and receptor mediated G-protein activation was studied by $\left[{ }^{35} \mathrm{~S}\right] \mathrm{GTP} \gamma \mathrm{S}$ binding assays performed on rat or guinea pig brain membranes (Fig. 4). All three bivalent peptide ligands effectively stimulated the activity of regulatory G-proteins in rat brain membranes with maximal stimulation levels of 149:126:149\% for BA55:BA61:BA62, respectively (Table 3). On the basis of these $E_{\max }$ values and those of Leu-enkephalin (H-YGGFL-OH), BA55 and BA62 are full agonists, while peptide BA61 seems to be a partial agonist ligand. In guinea pig brain membrane fractions, containing mainly KOP receptors, the stimulation order was BA55 $\approx$ BA62 $>$ BA61, indicating again the partial agonist nature of BA61. The effects of the three hybrid peptides were also compared with those of the simple mixtures of their peptide building components. Thus, curves for the mixtures were substantially different from the curves depicting the real hybrid compounds (see 
A

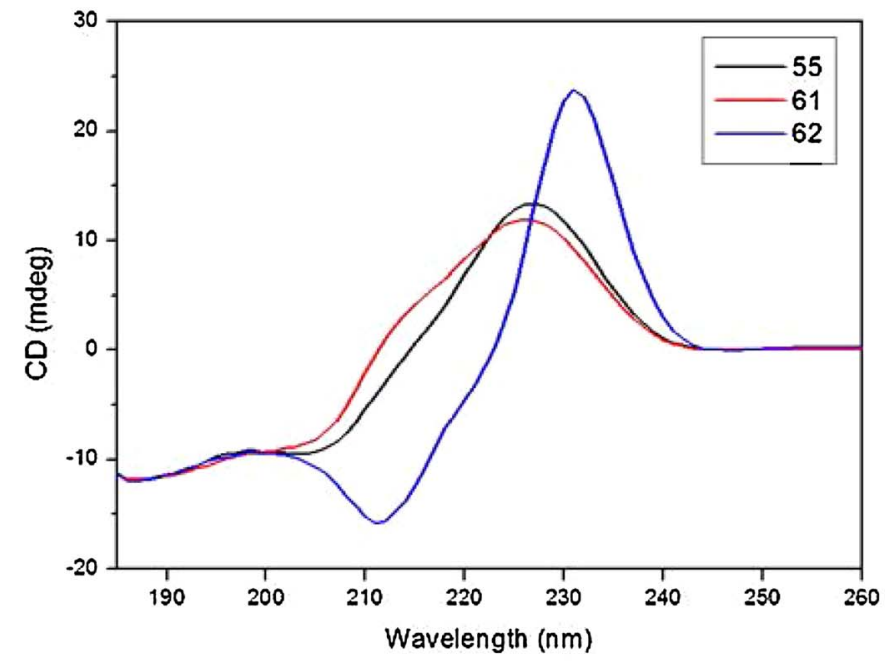

\begin{tabular}{|c|c|c|c|c|}
\hline Peptide & $\% \alpha$-helix & $\%$-sheet & $\%$ Turns & $\%$ Unordered \\
\hline BA55 & 17 & 32 & 18 & 33 \\
\hline BA61 & 5 & 63 & 27 & 5 \\
\hline BA62 & 50 & 22 & 8 & 20 \\
\hline
\end{tabular}
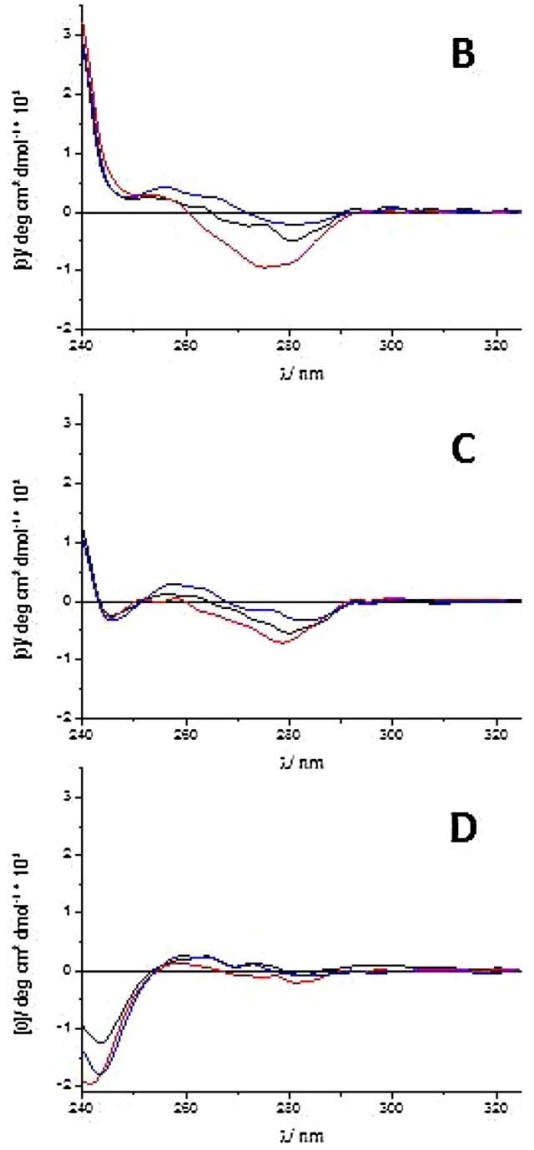

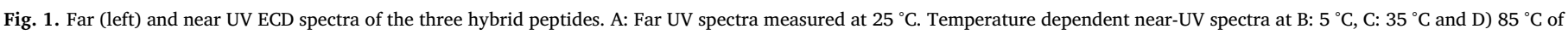
BA55 (black), BA61 (red) and BA62 (blue). (For interpretation of the references to colour in this figure legend, the reader is referred to the web version of this article.)

A

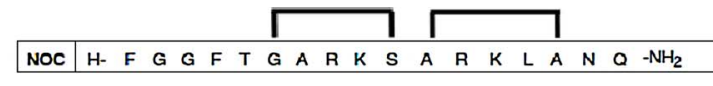

\begin{tabular}{|l|llllllll|lllll|ll|}
\hline \multirow{2}{*}{$B A 55$} & $H-$ & Y & $G$ & $G$ & $F$ & $G$ & $G$ & $G$ & $A$ & $Y$ & $Y$ & A & I & $K$ & $-\mathrm{NH}_{2}$ \\
\hline & $H-$ & Y & $G$ & $G$ & $F$ & $G$ & $G$ & $G$ & $R$ & $Y$ & $Y$ & $R$ & I & $K$ & $-\mathrm{NH}_{2}$ \\
\hline
\end{tabular}

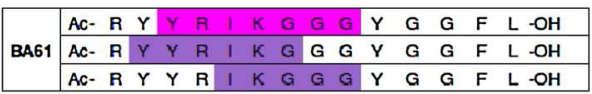

\begin{tabular}{|l|lllll|lllll|ll|}
\hline \multirow{2}{*}{$B A 62$} & $H-$ & $Y$ & $G$ & $G$ & $F$ & $R$ & $Y$ & $Y$ & $R$ & I & $K$ & $-\mathrm{NH}_{2}$ \\
\hline & $H-$ & $Y$ & $G$ & $G$ & $F$ & $R$ & $Y$ & $Y$ & $R$ & I & $K$ & $-\mathrm{NH}_{2}$ \\
\hline
\end{tabular}

$\begin{array}{llllllllllllll}1 & 2 & 3 & 4 & 5 & 6 & 7 & 8 & 9 & 10 & 11 & 12 & 13 & 14\end{array}$

B

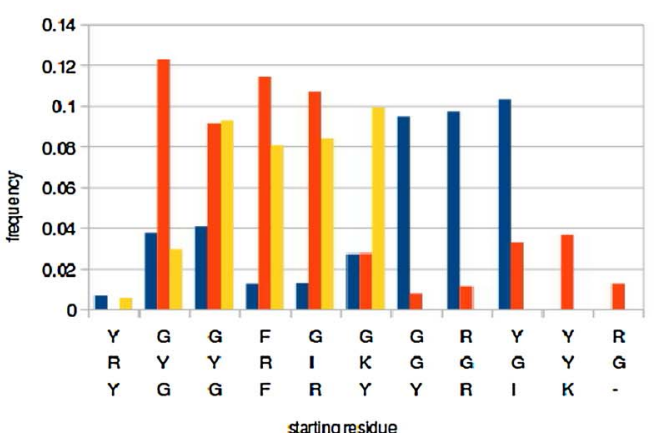

C

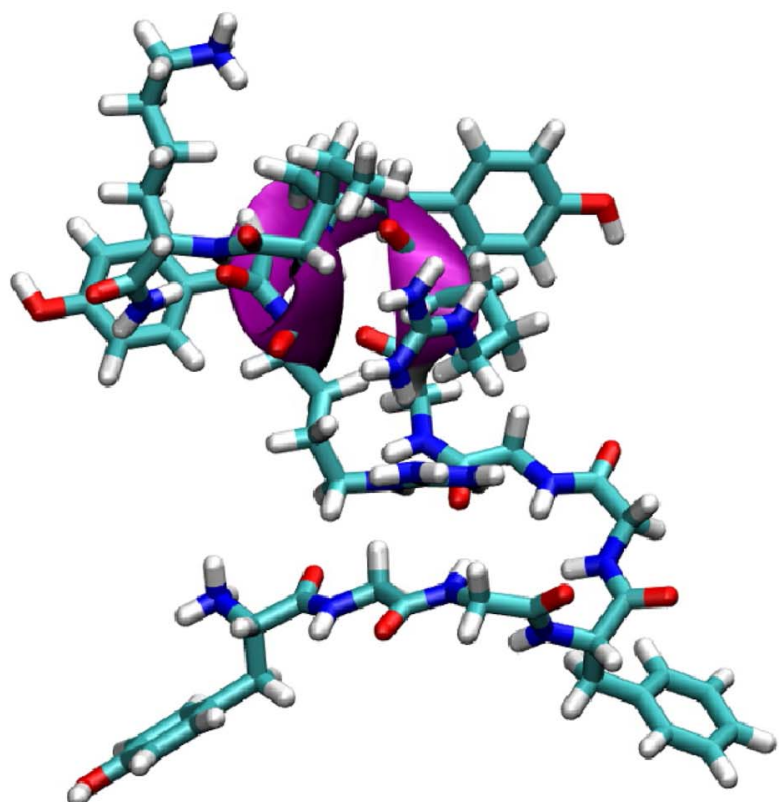

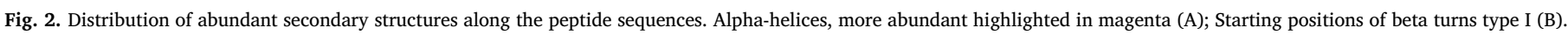

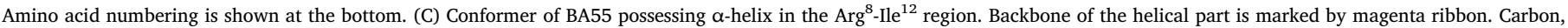

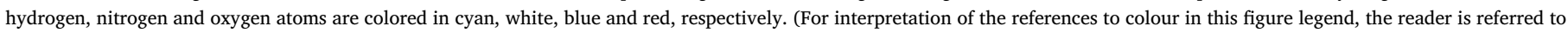
the web version of this article.) 

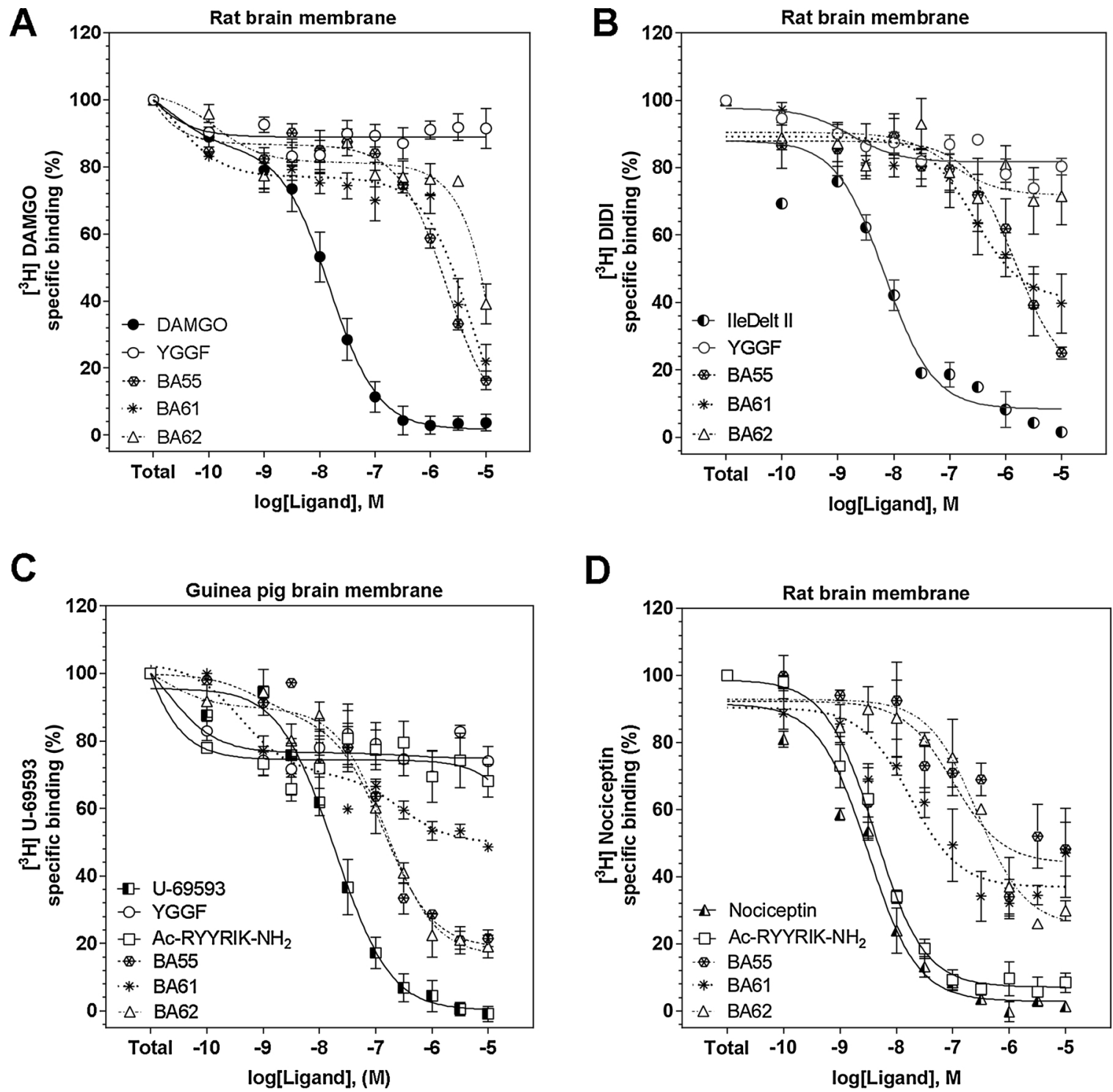

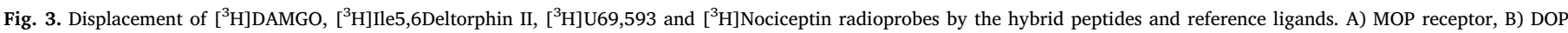

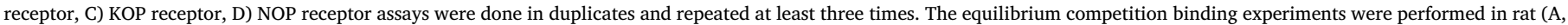
$\mathrm{B}$ and $\mathrm{D})$ and in guinea pig (C) brain membrane homogenates.

Table 1

Evaluation of the three bivalent peptides and reference compounds in radioligand binding assays.

\begin{tabular}{|c|c|c|c|c|c|}
\hline \multirow[t]{2}{*}{ Compounds } & & \multicolumn{4}{|c|}{ Affinity, $p \mathrm{IC}_{50} \pm$ S.E.M. $\left(\mathrm{K}_{\mathrm{i}}, \mathrm{nM}\right)$} \\
\hline & & {$\left[{ }^{3} \mathrm{H}\right] \mathrm{DAMGO}(\mathrm{MOPr})^{\mathrm{a}}$} & {$\left[{ }^{3} \mathrm{H}\right] \mathrm{Ile}^{5,6}$ Deltorphin II (DOPr) ${ }^{\mathrm{a}}$} & {$\left[{ }^{3} \mathrm{H}\right] \mathrm{U}-69,593(\mathrm{KOPr})^{\mathrm{b}}$} & {$\left[{ }^{3} \mathrm{H}\right]$ Nociceptin $(\mathrm{NOPr})^{\mathrm{a}}$} \\
\hline \multicolumn{6}{|l|}{ Selective ligands: } \\
\hline DAMGO (MOPr) & & $7.92 \pm 0.08$ & n.d. & n.d & n.d \\
\hline Ile $^{5,6}$ Deltorphin II (DOPr) & & n.d. & $8.16 \pm 0.12(1.3)$ & n.d & n.d. \\
\hline U-69,593 (KOPr) & & n.d. & n.d. & $7.7 \pm 0.07(11)$ & n.d. \\
\hline Nociceptin (NOPr) & & n.d. & n.d. & n.d. & $8.5 \pm 0.06(2.8)$ \\
\hline Ac-RYYRIK-NH ${ }_{2}$ & & n.d. & n.d. & n.d & $8.4 \pm 2.52(4.2)$ \\
\hline \multicolumn{6}{|l|}{ Fused hybrid peptides: } \\
\hline H-YGGFGGGRYYRIK-NH ${ }_{2}$ & BA55 & $5.72 \pm 0.16(743)$ & $5.96 \pm 0.2(387)$ & $6.9 \pm 0.1(58)$ & $6.56 \pm 2.38(91)$ \\
\hline Ac-RYYRIKGGGYGGFL-OH & BA61§ & $\begin{array}{l}10.6 \pm 0.8(0.02) \S \\
5.25 \pm 0.2(2451) \S\end{array}$ & $7.55 \pm 0.27(73)$ & $\begin{array}{l}8.8 \pm 0.2(0.9) \S \\
6.56 \pm 0.3(155) \S\end{array}$ & $7.75 \pm 3.32(16)$ \\
\hline H-YGGFRYYRIK-NH ${ }_{2}$ & BA62 & $5.24 \pm 0.45(2530)$ & $6.3 \pm 0.35(28)$ & $6.8 \pm 0.1(71)$ & $6.68 \pm 0.26(244)$ \\
\hline
\end{tabular}

§Results of two site fit exhibiting high-affinity binding site $\mathrm{K}_{\mathrm{i}}$ value (upper row) and low-affinity binding site $\mathrm{K}_{\mathrm{i}}$ (lower row) value, respectively. 
Table 2

Receptor-type selectivity comparisons for the hybrid peptides.

\begin{tabular}{|c|c|c|c|c|c|c|c|}
\hline \multirow[t]{2}{*}{ Peptides } & \multicolumn{6}{|c|}{ Binding selectivity ratios ${ }^{\mathrm{a}}$} & \multirow{2}{*}{$\frac{\% \text { relative affinity }^{\mathrm{b}}}{\text { MOP:DOP:KOP:NOP }}$} \\
\hline & $\mathrm{MOPr} / \mathrm{DOPr}$ & $\mathrm{MOPr} / \mathrm{KOPr}$ & $\mathrm{MOPr} / \mathrm{NOPr}$ & $\mathrm{DOPr} / \mathrm{KOPr}$ & $\mathrm{DOPr} / \mathrm{NOPr}$ & $\mathrm{KOPr} / \mathrm{NOPr}$ & \\
\hline BA55 & 1.9 & 13 & 8.2 & 6.7 & 4.3 & 0.6 & $4: 8: 54: 34$ \\
\hline BA61 & 34 & 16 & 153 & 0.5 & 4.6 & 9.7 & $0.5: 16: 8: 75$ \\
\hline BA62 & 90 & 36 & 10 & 0.4 & 0.1 & 0.3 & $1: 66: 26: 8$ \\
\hline
\end{tabular}

${ }^{\text {a }}$ Binding selectivity ratios were calculated from $\mathrm{K}_{\mathrm{i}}$ values. $\mathrm{K}_{\mathrm{i}}$-s for BA61/ $\left[{ }^{3} \mathrm{H}\right]$ DAMGO and BA61/ $\left[{ }^{3} \mathrm{H}\right] \mathrm{U}-69,593$ were calculated using values of the lower affinity sites.

${ }^{\mathrm{b}}$ Per cent relative affinities were quantified according to the formula given by Kosterlitz and Paterson (1980).

Table 3 for significant differences).

Antagonism by receptor type-selective ligands was also studied in $\left[{ }^{35}\right.$ S $]$ GTP $\gamma S$ binding experiments (Fig. 5). Stimulating effect of BA55 was significantly antagonised by DOP receptor, KOP receptor and NOP receptor antagonists, but not by cyprodime, a MOP receptor selective antagonist. G-protein activation by BA61 was substantially inhibited (significance level was $* *$ or $* * *$ ) in the presence of MOP receptor, DOP receptor and NOP receptor antagonists, while not with nor-BNI, the most selective KOP receptor antagonist, indicating that interaction of BA61 with the KOP receptor is weaker. Activating effect of the third hybrid peptide, BA62 was effectively antagonised by NOP receptor, DOP receptor and KOP receptor antagonist, but similarly to BA55, it was not inhibited by cyprodime. This suggests again that the MOP receptor is weakly involved in mediating the effects of these two peptides.

\subsection{Mouse vas deferens bioassay}

Fig. 6. depicts that the BA61, BA55, BA62 similarly to reference compounds inhibited the electrically-evoked MVD muscle contractions in concentration dependent manner. In MVD bioassay the $\mathrm{EC}_{50}(\mathrm{nM})$ values were 160, 3860, 19400 for BA61, BA55, BA62, respectively (Table 4). BA61 was lesser potent than any of the reference compounds but about 24- and 121-fold more potent than BA55 or BA62. The average $\mathrm{E}_{\max }$ was $100 \%$ for each compounds tested in the present work (Table 4). The DOP receptor antagonist naltrindole (NTI) $K_{e}$ values against BA61, BA55, BA62 and [d-Ala $\left.{ }^{2}, \mathrm{~d}_{-}-\mathrm{Leu}^{5}\right]$ enkephalin (DADLE, DOPr agonist) were all within the range of $0.14-1.06 \mathrm{nM}$. The $\mathrm{K}_{\mathrm{e}}(\mathrm{nM})$ value of norbinaltorphimine (nor-BNI, KOPr antagonist) against BA55, BA62 and EKC (KOPr agonist) were $1.25 \pm 0.41 \quad(\mathrm{n}=3)$, $0.41 \pm 0.12(n=4)$ and $0.51 \pm 0.17(n=3)$, respectively (Table 4). On the other side the naloxone (NX) $\mathrm{K}_{\mathrm{e}}$ values against BA55 and BA62 were $14.05 \pm 2.7(n=5)$ and $3.8 \pm 0.8(n=5) n M$, respectively. The calculated $\mathrm{K}_{\mathrm{e}}$ value of NX against DAMGO (typical MOPr agonist) was $1.01 \pm 0.14(\mathrm{n}=3)$ and of JTC-801 against nociceptin (NOPr agonist) was $480 \pm 72(\mathrm{n}=3) \mathrm{nM}$.

\section{Discussion}

Different types of pain of moderate to severe intensity is often treated with opioid compounds with variable success. However, central and peripheral origin unwanted effects such as respiratory depression, constipation, tolerance and dependence are among main factors that limit the use of opiate therapy. One strategy to overcome the major side effects and to prolong the analgesic efficiency of the applied drugs

\section{Rat brain membranes}

A

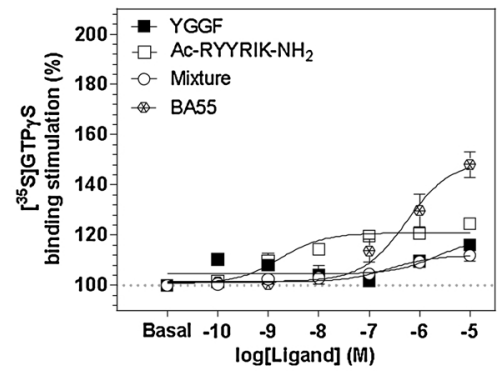

D

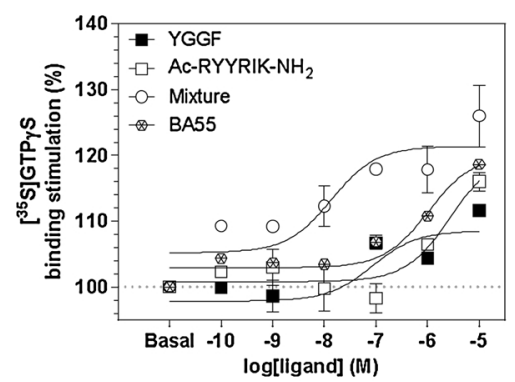

B

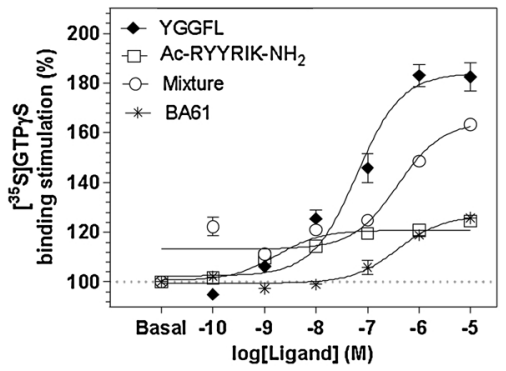

Guine pig brain membranes

E

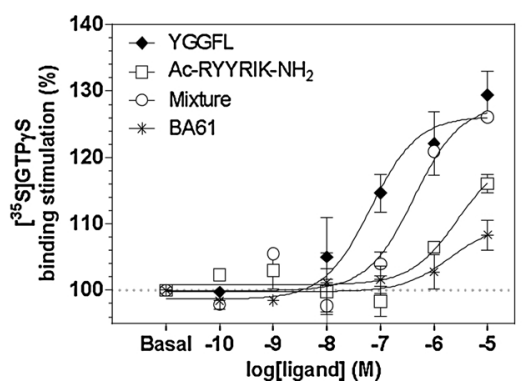

C

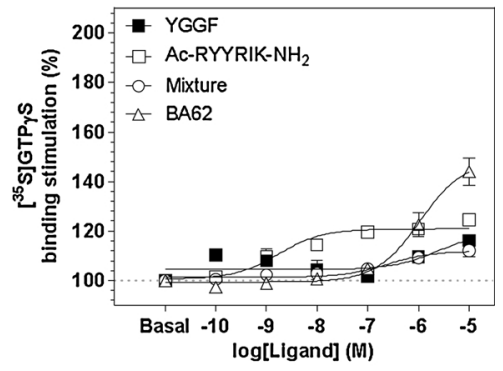

$\mathbf{F}$

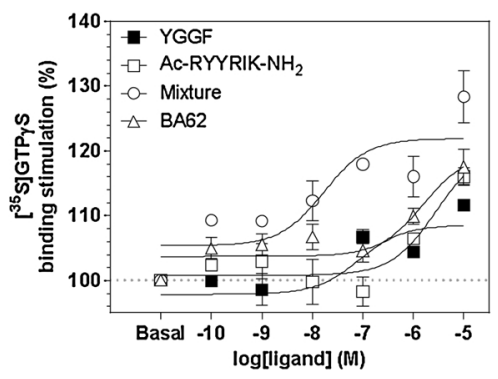

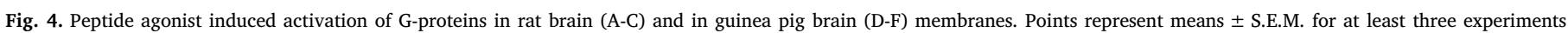

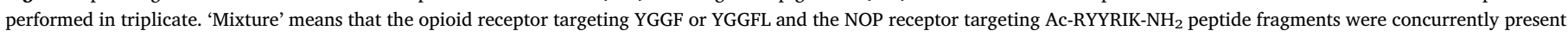
in the reaction tubes without their chemical cross-linking. 
Table 3

Summarized data of G-protein activation by the three chimeric peptides and their parent peptide sequences.

\begin{tabular}{|c|c|c|c|c|}
\hline \multirow[t]{2}{*}{ Peptides } & \multicolumn{2}{|l|}{ Rat brain membranes } & \multicolumn{2}{|l|}{ Guinea pig brain membranes } \\
\hline & Potency $p \mathrm{EC}_{50} \pm$ S.E.M. $\left(\mathrm{EC}_{50}, \mathrm{nM}\right)$ & Efficacy\% $\mathrm{E}_{\max }, \pm$ S.E.M. & Potency $p \mathrm{EC}_{50} \pm$ S.E.M. $\left(\mathrm{EC}_{50}, \mathrm{nM}\right)$ & Efficacy $\% \mathrm{E}_{\max }, \pm$ S.E.M \\
\hline Ac-RYYRIK-NH ${ }_{2}$ & $8.76 \pm 0.21(2)$ & $121 \pm 1$ & $5.57 \pm 0.35(2723$ & $120 \pm 5$ \\
\hline H-YGGF-OH & $5.63 \pm 0.59(2342)$ & $119 \pm 6$ & $7.07 \pm 0.48(85)$ & $108 \pm 3$ \\
\hline Mixture $1 \S$ & $6.61 \pm 0.37(247)$ & $112 \pm 2$ & $7.86 \pm 2.03(14)$ & $121 \pm 1$ \\
\hline Leu-enkephalin & $7.21 \pm 0.11(62)$ & $184 \pm 4$ & $7.18 \pm 0.27(67)$ & $126 \pm 3$ \\
\hline Mixture $2 \&$ & $6.42 \pm 0.14(381)$ & $164 \pm 3^{@}$ & $6.37 \pm 0.18(424)$ & $128 \pm 2$ \\
\hline BA55 & $6.26 \pm 0.18(388)$ & $149 \pm 5$ & $5.98 \pm 0.11(1039)$ & $120 \pm 1$ \\
\hline BA61 & $6.42 \pm 0.15(430)$ & $126 \pm 2$ & $5.72 \pm 0.60(1929)$ & $110 \pm 4$ \\
\hline BA62 & $5.97 \pm 0.15(442)$ & $149 \pm 4$ & $5.81 \pm 0.32(1560)$ & $120 \pm 3$ \\
\hline
\end{tabular}

$\S$ Mixture 1: Ac-RYYRIK-NH $\mathrm{N}_{2}+\mathrm{H}-\mathrm{YGGF}-\mathrm{OH}$, without chemical cross-linking of the components.

\& Mixture 2: Ac-RYYRIK-NH $\mathrm{N}_{2}+\mathrm{H}-\mathrm{YGGFL-OH}$, without chemical cross-linking of the components.

@ Significantly different from Ac-RYYRIK-NH ${ }_{2}(* * * \mathrm{p}<0.001)$ ANOVA followed by Bonferroni's post hoc test.

A

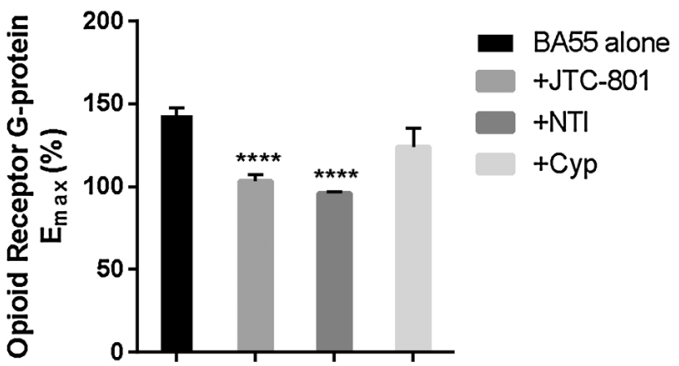

B

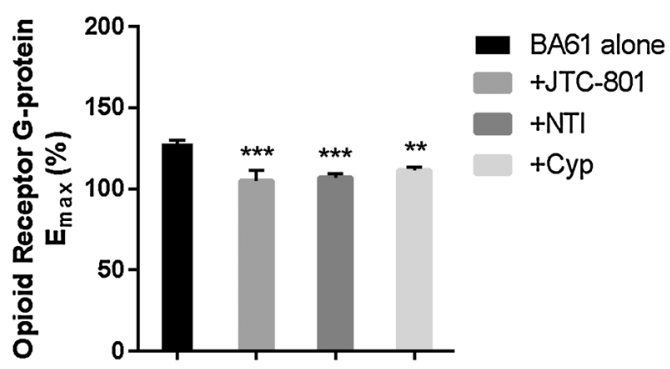

C

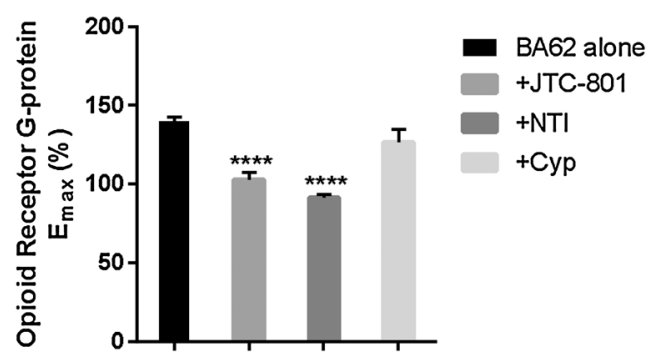

D

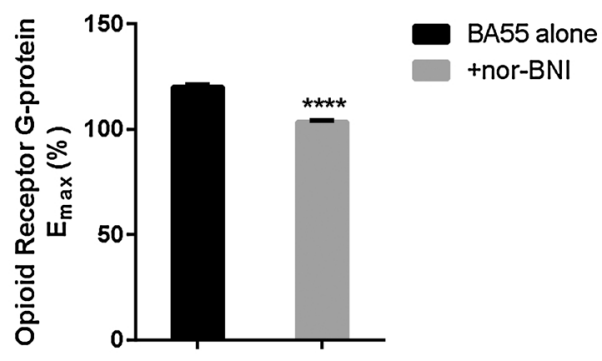

$\mathbf{E}$

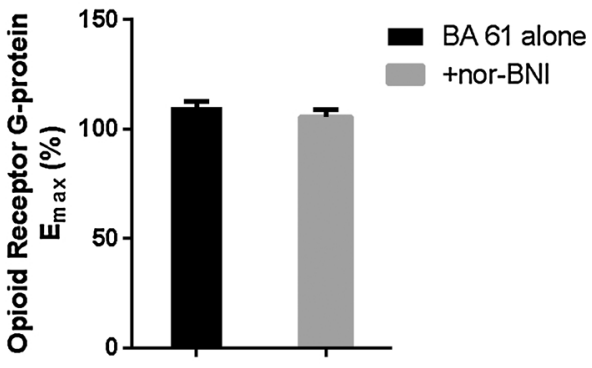

$\mathbf{F}$

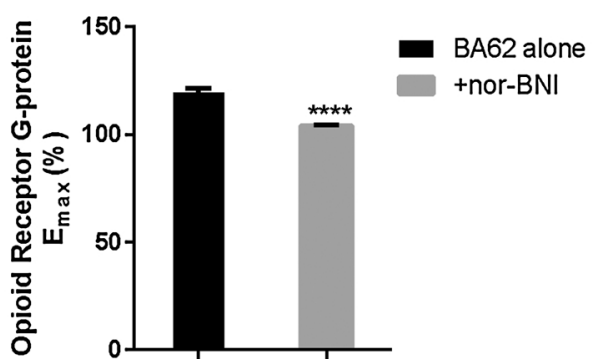

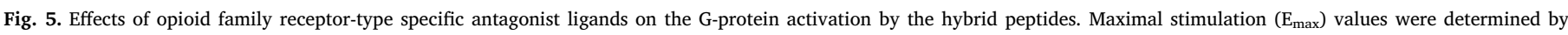

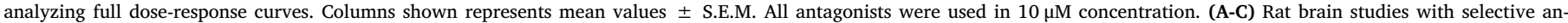

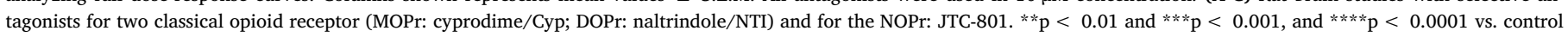

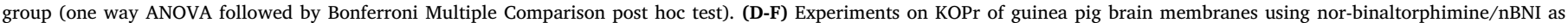
selective antagonist. ${ }^{* * *} \mathrm{p}<0.0001$ vs. control group (unpaired $t$-test with Welch's correction, two-tailed $\mathrm{P}$ value). 


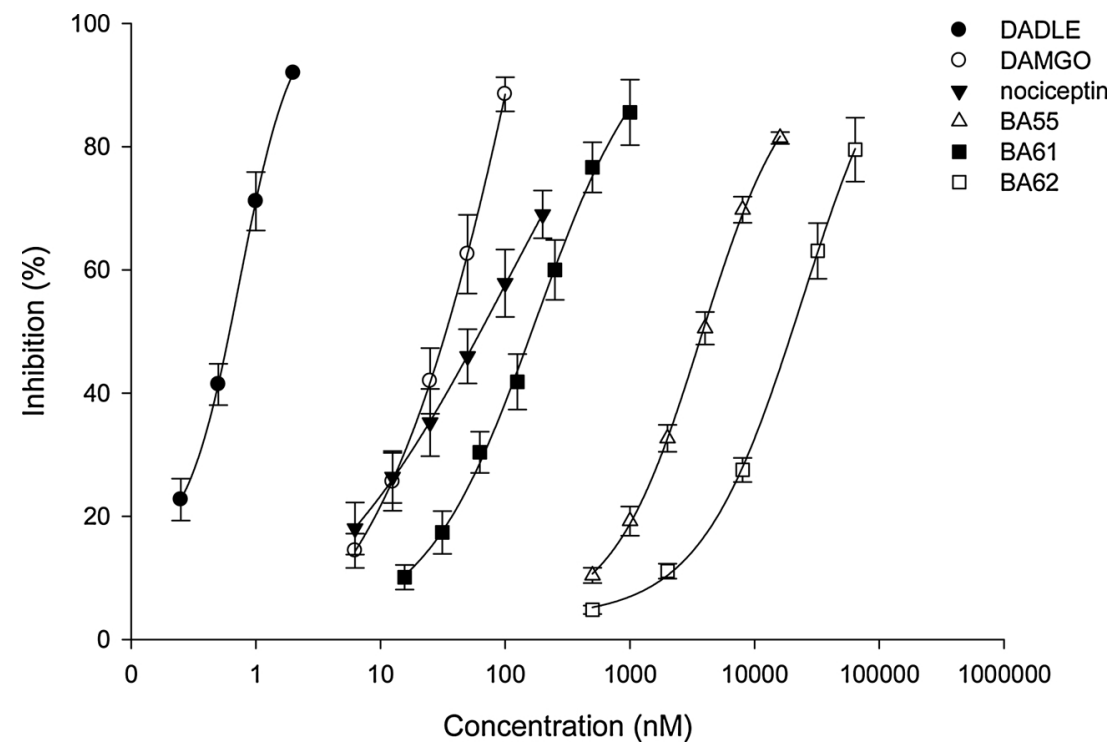

Fig. 6. Concentration-response curves for the bivalent peptides and reference opioid compounds on the electrically evoked contractions of the mouse vas deferens. Data are presented as mean \pm S.E.M. involves the creation of bi- or multifunctional compounds which contain hybridized structures $[21,38]$. Combination of opioid agonist and antagonist pharmacophores in a single molecule has been considered and extensively investigated e.g. [39], but opioids have also been combined with other bioactive neurotransmitters and peptide hormones that are involved in pain perception (e.g. neurotensin, neurokinins, such as substance $\mathrm{P}$, cholecystokinin, cannabinoids, etc. [40-42].

Three chimeric peptides were synthesized and studied in the current work. Amino acid sequence of the opioid peptide building blocks (YGGF) was selected according to the message-address model [43]), while the composition of the other pharmacophore (RYYRIK) based on artificial hexapeptide sequences isolated from a combinatorial peptide library [22]. Ac-RYYRIK- $\mathrm{NH}_{2}$ and Ac-RYYRIK-ol have been reported to display NOP receptor partial agonists with full antagonist properties in the presence of the pure agonist N/FQ $[24-26,44]$. Combination of NOP receptor antagonists with MOP receptor agonists would be perspective as analgesics, although for that reason non-peptide structures could be optimal. Transmembrane helix II of the NOP receptor was shown to be involved in the recognition of the Ac-RYYRIK- $\mathrm{NH}_{2}$ hexapeptide by photoaffinity labelling [45] while another molecular modelling and docking study described that both nociceptin and Ac-RYYRIK- $\mathrm{NH}_{2}$ can able to activate NOP receptor and their receptor-bound conformations have similar 3D structures [46].

Our novel peptide hybrids represent designed structures targeting at least two different GPCRs and perhaps their interacting complexes. Two peptides contain the YGGF opioid message motif at their N-terminus, and this region is followed by the C-terminally located Ac-RYYRIK- $\mathrm{NH}_{2}$ hexapeptide sequence. The two pharmacophores were connected directly in BA62, or interconnected with a triglycine (GGG) spacer sequence in BA55. The third chimeric peptide ligand bears a Ac-RYYRIK$\mathrm{NH}_{2}$ sequence at the N-terminus, that was combined with the YGGF opioid receptor recognising motif or message sequence [43] via a triglycine (GGG) spacer. It is worth noting that, our peptide sequences are different from those reported by [47]. These authors described MOP/ NOP receptor hybrid peptides consisting of full or partial dermorphin sequences found originally in frog skin [48]), fused with the Dooley's Ac-RYYRIK- $\mathrm{NH}_{2}$ hexapeptide [47].

Based on the different abundance in the peptides, the presence of turns close to the N-terminal may be important for the activity at NOP receptor. The presence of helices close to the N-terminal is contradictory. Due to its low percentage in BA61, the effect of helix on the affinity is presumably negligible and the RYYRIK segment is capable of exerting its effect. Comparing BA55 and BA62, despite they uniform Nterminal segment, the latter is inactive. This may be the consequence of helical segments close to N-termini, starting at Gly3. In addition, BA62 is the most abundant in helical segments according to CD spectra. In BA55, the helical segments are shifted from 3 residue away from the Nterminal, by the amount of the Gly-Gly-Gly spacer between the nociceptin fragment YGGF and RYYRIK. It seems that the helicity induced by Ac-RYYRIK- $\mathrm{NH}_{2}$ less disturbed the structure of the N-terminal fragment in BA55 than did in BA62. Additionally, BA55 is less helical than BA62, according to $\mathrm{CD}$.

In terms of binding affinity, the rank order of potency of the three peptides was BA61 > BA55 > BA62 at the KOP receptor. The good KOP receptor activity of BA55 and BA62 is not surprising, because the accumulation of positively charged amino acid side chains (two arginines and one lysine, R.R.K) at the opioid address domain is present in

Table 4

Characterization of the three bivalent peptide ligands and reference opioid agonist compounds in mouse vas deferens (MVD) bioassay.

\begin{tabular}{|c|c|c|c|c|c|}
\hline \multirow[t]{2}{*}{ Ligands } & \multirow[t]{2}{*}{$\mathrm{EC}_{50}(\mathrm{nM}) \pm$ S.E.M. } & \multicolumn{4}{|c|}{$\mathrm{K}_{\mathrm{e}}$ values for antagonists \pm S.E.M. (nM) } \\
\hline & & Naloxone (NX) & Naltrindole (NTI) & nor-BNI & JTC-801 \\
\hline DAMGO & $30 \pm 4$ & $1.01 \pm 0.14$ & * & $9.05 \pm 1.46$ & * \\
\hline DADLE & $0.58 \pm 0.06$ & $*$ & $0.13 \pm 0.02$ & $*$ & * \\
\hline EKC & $5.2 \pm 1.3$ & $7.9 \pm 0.54$ & $1.11 \pm 0.18$ & $0.51 \pm 0.17$ & * \\
\hline Nociceptin & $62 \pm 4$ & * & $*$ & * & $480 \pm 72$ \\
\hline BA55 & $3860 \pm 79$ & $14.05 \pm 2.7$ & $1.06 \pm 0.23$ & $1.25 \pm 0.41$ & * \\
\hline BA61 & $160 \pm 6$ & $17.4 \pm 4.45$ & $0.16 \pm 0.02$ & $1.26 \pm 0.4$ & $3330 \pm 765$ \\
\hline BA62 & $19400 \pm 142$ & $3.8 \pm 0.8$ & $1 \pm 0.3$ & $0.41 \pm 0.12$ & n.d. \\
\hline
\end{tabular}

The experiments were repeated at least three times. n.d.: not determined; *: no antagonist action, NX: naloxone, general opioid antagonist.

NTI: naltrindole, DOP receptor antagonist; nor-BNI, norbinaltorphimine, KOP receptor antagonist; JTC-801: NOP receptor antagonist. 
various prodynorphin- (PDYN) derived endogenous opioid peptides [49], including dynorphin A 1-17 (RR...K.K), dynorphin B or rimorphin (RR.K...) and $\alpha$-neo-endorphin (RK.K). These data are consistent with our hypothesis that appropriate modifications in the address domain of dynorphin analogues may affect efficacy. Our results confirm also the importance of the opioid "message" displayed by many opioid ligands but also suggest a potential role of receptor recognition and activation that may be mediated by EL2 through interactions with the "address" component of dynorphin-like peptides [50]. The good MOP and KOP receptor affinities of BA61 (Ac-RYYRIKGGGYGGF-OH) were not expected, because this peptide has no N-terminal tyrosine (Tyr, Y) at all, which is common in all endogenous opioid peptides, $\beta$-endorphin, enkephalins, dynorphins and neo-endorphins. Moreover, the original opioid message tetrapeptide is hidden at the C-terminus of BA61, so the C-terminal address region of this synthetic oligopeptide ligand has no positively charged amino acids important for the KOP-receptor recognition. The high KOP receptor affinity was not observed among the Dooley's hexapeptide analogues described earlier [24-27,51].

Peptides having the opioid message sequence YGGF at the N-terminus remained comparable full agonists with Leu-enkephalin (YGGFL) when their G-protein activating properties were studied in $\left[{ }^{35} \mathrm{~S}\right] \mathrm{GTP} \gamma \mathrm{S}$ binding experiments (Fig. 3). The $\mathrm{E}_{\max }$ (efficacy) values went up to 149, 149 and $184 \%$ for BA55, BA62 and Leu-enkephalin, respectively. The third peptide starting with Ac-RYYRIK- $\mathrm{NH}_{2}$ sequence possesses partial agonist properties reaching an $\mathrm{E}_{\max }$ value of $126 \%$ (Table 3 ). AcRYYRIK- $\mathrm{NH}_{2}$ hexapeptides were consistently found to be partial agonists and/or antagonist ligands in a variety of biochemical and pharmacological assays [24-27,52]. It is also worthy to mention here that in the G-protein stimulation assays, simple mixtures composed from the parent peptide components of the hybridised ligands behaved differently when their effects were compared to the multitarget fused sequences bearing real chemical connections, i.e., covalent bonding. AcRYYRIK- $\mathrm{NH}_{2}$ was able to inhibit the stimulation by Leu-enkephalin (Fig. 3B panel), when it was present in the mixture, indicating that the Dooley's peptide has opioid antagonist activity in addition to the wellknown antagonism observed at the NOP receptors. In guinea pig brain membranes, where KOP receptors are predominant, BA55 (Fig. 3D panel) and BA62 (Fig. 3F panel) mediated effects were additive by mixing them with the opioid tetrapeptide YGGF, the latter represents a minimum structure for opioid receptor activation [53].

BA55 and BA62 were significantly antagonized by the KOP receptor specific nor-binaltorphimine (nor-BNI) in the $\left[{ }^{35} \mathrm{~S}\right] \mathrm{GTP} \gamma \mathrm{S}$ binding experiments (Fig. 4D and F panels), while BA61 was not affected by the addition of nor-BNI (Fig. 4E panel). This phenomenon supports the KOP receptor preference of those hybrid peptides that contain the Nterminal opioid message sequence YGGF in the correct, N-terminally position. Interestingly enough, when the opioid tetrapeptide is located at the $\mathrm{C}$ terminus of the hybrid compound BA61, only nor-BNI was not able to antagonize the stimulation, while JTC-801, cyprodime and naltrindole produced significant inhibitions.

For a comparison, we extended our study to examine the pharmacological properties of the test peptides in MVD, which hosting MOP, DOP, KOP and NOP receptors. The order of potency in this tissue was BA61 > BA55 > BA62. Applying different opioid receptor subtype antagonists revealed that, BA55 and BA62 showed non selective opioid receptor subtype mediated action (MOP, DOP and KOP receptor), whereas BA61 displayed affinity for DOP and NOP but not for KOP receptor. Based on the above mentioned data, the test peptides displayed potency order that matches what was determined in the binding assay. This similarity was also found in the action of BA55 and BA62 for KOP. In addition, the two peptides showed DOP receptor-mediated effect. However, the selectivity of these two peptides for DOP receptor was less that of DADLE, indicated by dissociation constants (Table 4). The involvement of DOP and KOP receptor in the action of BA55 and BA62 is not surprising, since the two peptides have the same address and message domains. In contrast, BA61 has different N-terminal domain (Ac-R), and yet different C-terminal (carboxyl group). This observation is in good agreement with previous results, according to which the free carboxyl group containing enkephalins preferred DOP receptors $[54,55]$. Moreover, keeping in mind that BA61 has N-terminal preferred by NOP receptor [24-26,44]. Consequently, the observed pharmacological effect of this peptide might be stand on these changes. Indeed, we could not parallel measure the contribution of NOP and DOP receptor mediated by BA61, because MVD hosting all opioid receptor subtypes but the DOPr reserve is high $[56,57]$. This tendency makes MVD very sensitive for DOP receptor mediated effect of BA61. Therefore, we measured the effect of JTC-801 against BA61 in the presence of NTI, a selective DOP receptor antagonist. Applying this strategy we could show the action of BA61 on NOP receptor.

Based on the different abundance in the peptides, the presence of turns close to the N-terminal may be important for the activity at NOP receptor. The presence of helices close to the N-terminal is contradictory. Due to its low percentage in BA61, the effect of helix on the affinity is presumably negligible and the Ac-RYYRIK segment is capable of exerting its effect. Comparing BA55 and BA62, despite their uniform $\mathrm{N}$-terminal segment, the latter is inactive. This may be the consequence of helical segments close to N-termini, starting at $\mathrm{Gly}^{3}$. In addition, BA62 is the most abundant in helical segments according to CD spectra. In BA55, the helical segments are shifted from 3 residue away from the $\mathrm{N}$-terminal, by the amount of the Gly-Gly-Gly spacer between the nociceptin fragment YGGF and RYYRIK. It seems that the helicity induced by RYYRIK disturbed less the structure of the N-terminal fragment in BA55 than did in BA62. Additionally, the location of the helices in BA55 is very similar to that in helix-constrained nociceptin analogues [58] (Fig. 2) allowing a nociceptin-like activation mechanism. A typical conformer of peptide BA55 having helical C-terminal tail is shown in Fig. 2C.

Summarizing the results we can tell that each of the three novel hybrid peptides carries either opioid- or NOP receptor interacting properties or both, as expected during the design. One of the original goal that was the combination of the natural opioid agonist tetrapeptide "message" region with the artificial NOP-receptor selective antagonist (RYYRIK) peptide sequence is fulfilled, although some of the data did not yield the desired specific result. On the other hand, fine selectivity for an individual receptor of the novel peptides was not expected, because these are targeting at least two receptor proteins. The resulting hybrid structures can at least partly served as bivalent compounds for receptor labelling. Our most important and surprising observation is that BA61 behaved as partial agonist at the opioid receptors notwithstanding there is no N-terminal opioid "message" sequence in its structure. Taken together, the tridecapeptide H-YGGFGGGRYYRIK-NH $\mathrm{N}_{2}$ (BA55) is moderately potent in the MVD bioassay, it exhibits a KOP/ NOP receptor preference, and it has mainly unordered conformations in solution. The shorter hybrid decapeptide composed of opioid message and NOP receptor/nociceptin address domains, H-YGGFRYYRIK-NH $\mathrm{N}_{2}$ (BA62), exhibited the weakest inhibition on the mouse vas deferens, it has more $\alpha$-helix in its structure, and this chimeric peptide has been the most efficacious agonist in the G-protein stimulation assays. The third bivalent compound, the tetradecapeptide Ac-RYYRIKGGGYGGFL-OH (BA61) seems to be a quaint KOP receptor ligand, although its amino acid sequence is completely differing from those of the kappa-receptor selective endogenous opioid peptides. Bearing a NOP receptor recognising hexapeptide sequence, the high affinity of BA61 toward the NOP receptor has also been restored. Experiments on receptor co-expressing cell lines are in progress to examine the effects of these hybrid peptides on MOP-NOP receptor heterodimers.

\section{Acknowledgements}

This research was supported by an OTKA-108518 grant provided by National Research, Development and Innovation Office (NKFIH), Budapest, Hungary. 


\section{References}

[1] M. Waldhoer, S.E. Bartlett, J.L. Whistler, Opioid receptors, Annu. Rev. Biochem. 73 (2004) 953-990, http://dx.doi.org/10.1146/annurev.biochem.73.011303.073940.

[2] B.L. Kieffer, C.J. Evans, Opioid receptors: from binding sites to visible molecules in vivo, Neuropharmacology 56 (Suppl. 1) (2009) 205-212, http://dx.doi.org/10. 1016/j.neuropharm.2008.07.033.

[3] Y. Feng, X. He, Y. Yang, D. Chao, L.H. Lazarus, Y. Xia, Current research on opioid receptor function, Curr. Drug Targets 13 (2012) 230-246 (accessed 14 September 2016), http://www.pubmedcentral.nih.gov/articlerender.fcgi?artid = 3371376\& tool $=$ pmcentrez\&rendertype $=$ abstract.

[4] B.M. Cox, M.J. Christie, L. Devi, L. Toll, J.R. Traynor, Challenges for opioid receptor nomenclature: IUPHAR review 9, Br. J. Pharmacol. 172 (2015) 317-323, http://dx. doi.org/10.1111/bph.12612.

[5] C.W. Stevens, Bioinformatics and evolution of vertebrate nociceptin and opioid receptors, Vitam. Horm. 97 (2015) 57-94, http://dx.doi.org/10.1016/bs.vh.2014. 10.002

[6] S. Benyhe, F. Zador, F. Otvös, Biochemistry of opioid (morphine) receptors: binding, structure and molecular modelling, Acta Biol. Szeged 59 (2015) 17-37.

[7] J.C. Meunier, C. Mollereau, L. Toll, C. Suaudeau, C. Moisand, P. Alvinerie, J.L. Butour, J.C. Guillemot, P. Ferrara, B. Monsarrat, Isolation and structure of the endogenous agonist of opioid receptor-like ORL1 receptor, Nature 377 (1995) 532-535, http://dx.doi.org/10.1038/377532a0.

[8] R.K. Reinscheid, H.P. Nothacker, A. Bourson, A. Ardati, R.A. Henningsen, J.R. Bunzow, D.K. Grandy, H. Langen, F.J. Monsma, O. Civelli, Orphanin FQ: a neuropeptide that activates an opioidlike $\mathrm{G}$ protein-coupled receptor, Science 270 (1995) 792-794 (Accessed 14 September 2016), http://www.ncbi.nlm.nih.gov/ pubmed/7481766.

[9] J. Hughes, T.W. Smith, H.W. Kosterlitz, L.A. Fothergill, B.A. Morgan, H.R. Morris, Identification of two related pentapeptides from the brain with potent opiate agonist activity, Nature 258 (1975) 577-580 (Accessed 14 September 2016), http:// www.ncbi.nlm.nih.gov/pubmed/1207728.

[10] C.H. Li, D. Chung, Isolation and structure of an untriakontapeptide with opiate activity from camel pituitary glands, Proc. Natl. Acad. Sci. U. S. A. 73 (1976) 1145-1158 (Accessed 14 September 2016), http://www.pubmedcentral.nih.gov/ articlerender.fcgi? artid $=430217 \&$ tool $=$ pmcentrez\&rendertype $=$ abstract.

[11] A. Goldstein, W. Fischli, L.I. Lowney, M. Hunkapiller, L. Hood, Porcine pituitary dynorphin: complete amino acid sequence of the biologically active heptadecapeptide, Proc. Natl. Acad. Sci. U. S. A. 78 (1981) 7219-7223 (Accessed 14 September 2016), http://www.pubmedcentral.nih.gov/articlerender.fcgi?artid = 349228\&tool $=$ pmcentrez\&rendertype $=$ abstract.

[12] S.D. Bryant, Y. Jinsmaa, S. Salvadori, Y. Okada, L.H. Lazarus, Dmt and opioid peptides: a potent alliance, Biopolymers 71 (2003) 86-102, http://dx.doi.org/10. 1002/bip.10399.

[13] L. Gentilucci, New trends in the development of opioid peptide analogues as advanced remedies for pain relief, Curr. Top. Med. Chem. 4 (2004) 19-38 (Accessed 14 September 2016), http://www.ncbi.nlm.nih.gov/pubmed/14754374.

[14] A. Janecka, J. Fichna, T. Janecki, Opioid receptors and their ligands, Curr. Top. Med. Chem. 4 (2004) 1-17 (Accessed 14 September 2016), http://www.ncbi.nlm. nih.gov/pubmed/14754373.

[15] A. Janecka, R. Staniszewska, J. Fichna, Endomorphin analogs, Curr. Med. Chem. 14 (2007) 3201-3208 (Accessed 14 September 2016), http://www.ncbi.nlm.nih.gov/ pubmed/18220754.

[16] P.W. Schiller, Opioid peptide-derived analgesics, AAPS J. 7 (2005) E560-E575, http://dx.doi.org/10.1208/aapsj070356.

[17] L. Gentilucci, A. Tolomelli, F. Squassabia, Peptides and peptidomimetics in medicine, surgery and biotechnology, Curr. Med. Chem. 13 (2006) 2449-2466 (Accessed 14 September 2016), http://www.ncbi.nlm.nih.gov/pubmed/16918365.

[18] A.K. Giri, V.J. Hruby, Investigational peptide and peptidomimetic $\mu$ and $\delta$ opioid receptor agonists in the relief of pain, Expert Opin. Investig. Drugs. 23 (2014) 227-241, http://dx.doi.org/10.1517/13543784.2014.856879.

[19] A.M. Lipkowski, Double-enkephalins-synthesis, activity on guinea-pig ileum, and analgesic effect, Peptides 3 (1982) 697-700 (Accessed 14 September 2016), http:// www.ncbi.nlm.nih.gov/pubmed/7134034.

[20] F. Feliciani, F. Pinnen, A. Stefanucci, R. Costante, I. Cacciatore, G. Lucente, A. Mollica, Structure-activity relationships of biphalin analogs and their biological evaluation on opioid receptors., Mini Rev, Med. Chem. 13 (2013) 11-33 (Accessed 14 September 2016), http://www.ncbi.nlm.nih.gov/pubmed/22512573.

[21] P. Kleczkowska, A.W. Lipkowski, D. Tourwé, S. Ballet, Hybrid opioid/non-opioid ligands in pain research, Curr. Pharm. Des. 19 (2013) 7435-7450 (Accessed 2 November 2016), http://www.ncbi.nlm.nih.gov/pubmed/23448481.

[22] C.T. Dooley, C.G. Spaeth, I.P. Berzetei-Gurske, K. Craymer, I.D. Adapa, S.R. Brandt, R.A. Houghten, L. Toll, Binding and in vitro activities of peptides with high affinity for the nociceptin/orphanin FQ receptor, ORL1, J. Pharmacol. Exp. Ther. 283 (1997) 735-741 http://www.ncbi.nlm.nih.gov/pubmed/9353393.

[23] H. Berger, E. Albrecht, G. Wallukat, M. Bienert, Antagonism by acetyl-RYYRIK-NH2 of $\mathrm{G}$ protein activation in rat brain preparations and of chronotropic effect on rat cardiomyocytes evoked by nociceptin/orphanin FQ, Br. J. Pharmacol. 126 (1999) 555-568, http://dx.doi.org/10.1038/sj.bjp.0702353.

[24] C. Kawano, K. Okada, T. Honda, T. Nose, K. Sakaguchi, T. Costa, Y. Shimohigashi, Structural requirements of nociceptin antagonist Ac-RYYRIK-NH2 for receptor binding, J. Pept. Sci. 8 (2002) 561-579, http://dx.doi.org/10.1002/psc.415.

25] L. Kocsis, G. Orosz, A. Magyar, M. Al-Khrasani, E. Kató, A.Z. Rónai, B. Bes, J.C. Meunier, O. Gündüz, G. Tóth, A. Borsodi, S. Benyhe, Nociceptin antagonism: probing the receptor by N-acetyl oligopeptides, Regul. Pept. 122 (2004) 199-207, http://dx doi.org/10.1016/j.regpep. 2004.06.019.

[26] O. Gündüz, F. Sipos, B. Spagnolo, L. Kocsis, A. Magyar, G. Orosz, A. Borsodi, G. Caló, S. Benyhe, In vitro binding and functional studies of Ac-RYYRIK-ol and its derivatives, novel partial agonists of the nociceptin/orphanin $\mathrm{F} / \mathrm{Q}$ receptor, Neurosignals 15 (2006) 91-101, http://dx.doi.org/10.1159/000094743.

[27] O. Gündüz, A. Rizzi, A. Baldisserotto, R. Guerrini, B. Spagnolo, E.C. Gavioli, L. Kocsis, A. Magyar, S. Benyhe, A. Borsodi, G. Calò, In vitro and in vivo pharmacological characterization of the nociceptin/orphanin FQ receptor ligand AcRYYRIK-ol, Eur. J. Pharmacol. 539 (2006) 39-48, http://dx.doi.org/10.1016/j. ejphar.2006.03.075.

[28] D. Frishman, P. Argos, Knowledge-based protein secondary structure assignment, Proteins Struct, Funct. Genet. 23 (1995) 566-579, http://dx.doi.org/10.1002/prot. 340230412.

[29] E. Bojnik, J. Farkas, A. Magyar, C. Tömböly, U. Güclü, O. Gündüz, A. Borsodi, M. Corbani, S. Benyhe, Selective and high affinity labeling of neuronal and recombinant nociceptin receptors with the hexapeptide radioprobe $[(3) \mathrm{H}] \mathrm{Ac}-$ RYYRIK-ol, Neurochem. Int. 55 (2009) 458-466, http://dx.doi.org/10.1016/j. neuint 2009.04 .014

[30] F. Zádor, D. Kocsis, A. Borsodi, S. Benyhe, Micromolar concentrations of rimonabant directly inhibits delta opioid receptor specific ligand binding and agonist-induced G-protein activity, Neurochem. Int. 67 (2014) 14-22, http://dx.doi.org/10. 1016/j.neuint.2013.12.005

[31] S. Benyhe, J. Farkas, G. Tóth, M. Wollemann, Met5-enkephalin-Arg6-Phe7, an endogenous neuropeptide, binds to multiple opioid and nonopioid sites in rat brain, $\mathrm{J}$. Neurosci. Res. 48 (1997) 249-258.

[32] J.R. Traynor, S.R. Nahorski, Modulation by mu-opioid agonists of guanosine-5'-O(3-[35S] thio)triphosphate binding to membranes from human neuroblastoma SHSY5Y cells, Mol. Pharmacol. 47 (1995) 848-854 (Accessed 13 March 2017), http:// www.ncbi.nlm.nih.gov/pubmed/7723747.

[33] A.Z. Rónai, L. Gráf, J.I. Székely, Z. Dunai-Kovács, S. Bajusz, Differential behaviour of LPH-(61-91)-peptide in different model systems: comparison of the opioid activities of LPH-(61-91)-peptide and its fragments, FEBS Lett. 74 (1977) 182-184, http://dx.doi.org/10.1016/0014-5793(77)80842-9.

[34] R.G. Pertwee, S.R. Fernando, G. Griffin, W. Ryan, R.K. Razdan, D.R. Compton, B.R. Martin, Agonist-antagonist characterization of 6 '-cyanohex-2'-yne- $\Delta 8$-tetrahydrocannabinol in two isolated tissue preparations, Eur. J. Pharmacol. 315 (1996) 195-201, http://dx.doi.org/10.1016/S0014-2999(96)00631-0.

[35] H.W. Kosterlitz, A.J. Watt, Kinetic parameters of narcotic agonists and antagonists, with particular reference to N-allylnoroxymorphone (naloxone), Br. J. Pharmacol. Chemother. 33 (1968) 266-276 http://www.pubmedcentral.nih.gov/articlerender. fcgi artid $=1570231 \&$ tool $=$ pmcentrez\&rendertype $=$ abstract.

[36] N. Sreerama, R.W. Woody, Estimation of protein secondary structure from circular dichroism spectra: comparison of CONTIN, SELCON, and CDSSTR methods with an expanded reference set, Anal. Biochem. 287 (2000) 252-260, http://dx.doi.org/10. 1006/abio.2000.4880.

[37] H.W. Kosterlitz, S.J. Paterson, J.S. Morley, Characterization of opioid receptors in nervous tissue [and discussion], Proc. R. Soc. B Biol. Sci. 210 (1980) 113-122, http://dx.doi.org/10.1098/rspb.1980.0122.

[38] S. Dvoracsko, A. Stefanucci, E. Novellino, A. Mollica, The design of multitarget ligands for chronic and neuropathic pain, Future Med. Chem.. 7 (2015) 2469-2483, http://dx.doi.org/10.4155/fmc.15.156.

[39] K. Guillemyn, J. Starnowska, C. Lagard, J. Dyniewicz, E. Rojewska, J. Mika, N.N. Chung, V. Utard, P. Kosson, A.W. Lipkowski, L. Chevillard, P. Arranz-Gibert, M. Teixidó, B. Megarbane, D. Tourwé, F. Simonin, B. Przewlocka, P.W. Schiller, S. Ballet, Bifunctional peptide-Based opioid agonist-Nociceptin antagonist ligands for dual treatment of acute and neuropathic pain, J. Med. Chem. 59 (2016) 3777-3792, http://dx.doi.org/10.1021/acs.jmedchem.5b01976.

[40] A. Mollica, R. Costante, A. Stefanucci, F. Pinnen, G. Luisi, S. Pieretti, A. Borsodi, E. Bojnik, S. Benyhe, Hybrid peptides endomorphin-2/DAMGO: design, synthesi and biological evaluation, Eur. J. Med. Chem. 68 (2013) 167-177, http://dx.doi. org/10.1016/j.ejmech.2013.07.044.

[41] P. Kleczkowska, E. Bojnik, A. Leśniak, P. Kosson, I. Van den Eynde, S. Ballet, S. Benyhe, D. Tourwé, A.W. Lipkowski, Identification of Dmt-D-Lys-Phe-Phe-OH as a highly antinociceptive tetrapeptide metabolite of the opioid-neurotensin hybrid peptide PK20, Pharmacol. Rep. 65 (2013) 836-846 (Accessed 14 September 2016), http://www.ncbi.nlm.nih.gov/pubmed/24145077.

[42] A. Kowalczyk, P. Kleczkowska, M. Rẹkawek, K. Kulik, A. Lesniak, A. Erdei, A. Borics, C. Martin, K. Pawlik, A.W. Lipkowski, S. Benyhe, H. Makulska-Nowak, S. Ballet, M. Bujalska-Zadrozny, Biological evaluation and molecular docking studies of AA3052, a compound containing a (-selective opioid peptide agonist DALDA and d-Phe-Phe-d-Phe-Leu-Leu-NH2, a substance P analogue, Eur. J. Pharm. Sci. 93 (2016) 11-20, http://dx.doi.org/10.1016/j.ejps.2016.07.009.

[43] R. Schwyzer, Molecular mechanism of opioid receptor selection, Biochemistry 25 (1986) 6335-6342, http://dx.doi.org/10.1021/bi00368a075.

[44] H. Berger, R. Bigoni, E. Albrecht, R.M. Richter, E. Krause, M. Bienert, G. Calo', The nociceptin/orphanin FQ receptor ligand acetyl-RYYRIK-amide exhibits antagonistic and agonistic properties, Peptides 21 (2000) 1131-1139 (Accessed 2 November 2016), http://www.ncbi.nlm.nih.gov/pubmed/10998548.

[45] B. Bes, J.-C. Meunier, Identification of a hexapeptide binding region in the nociceptin (ORL1) receptor by photo-affinity labelling with Ac-Arg-Bpa-Tyr-Arg-TrpArg-NH2, Biochem. Biophys. Res. Commun. 310 (2003) 992-1001 (Accessed 2 November 2016), http://www.ncbi.nlm.nih.gov/pubmed/14550303.

[46] N. Akuzawa, S. Takeda, M. Ishiguro, Structural modelling and mutation analysis of a nociceptin receptor and its ligand complexes, J. Biochem. 141 (2007) 907-916, http://dx.doi.org/10.1093/jb/mvm100.

[47] S. Kawano, R. Ito, M. Nishiyama, M. Kubo, T. Matsushima, M. Minamisawa, 
A. Ambo, Y. Sasaki, Receptor binding properties and antinociceptive effects of chimeric peptides consisting of a micro-opioid receptor agonist and an ORL1 receptor antagonist, Biol. Pharm. Bull. 30 (2007) 1260-1264 (Accessed 14 September 2016), http://www.ncbi.nlm.nih.gov/pubmed/17603164.

[48] V. Erspamer, P. Melchiorri, M. Broccardo, G.F. Erspamer, P. Falaschi, G. Improta, L. Negri, T. Renda, The brain-gut-skin triangle: new peptides, Peptides 2 (1981) 7-16, http://dx.doi.org/10.1016/0196-9781(81)90003-6.

[49] H. Kakidani, Y. Furutani, H. Takahashi, M. Noda, Y. Morimoto, T. Hirose, M. Asai, S. Inayama, S. Nakanishi, S. Numa, Cloning and sequence analysis of cDNA for porcine beta-neo-endorphin/dynorphin precursor, Nature 298 (1982) 245-249 (Accessed 14 September 2016), http://www.ncbi.nlm.nih.gov/pubmed/6123953.

[50] G. Paterlini, P.S. Portoghese, D.M. Ferguson, Molecular simulation of dynorphin A(1-10) binding to extracellular loop 2 of the kappa-opioid receptor. A model for receptor activation, J. Med. Chem. 40 (1997) 3254-3262, http://dx.doi.org/10. $1021 / \mathrm{jm} 970252 \mathrm{j}$.

[51] J. Li, H. Nishimura, A. Matsushima, Y. Shimohigashi, N-methylthioacetylation of RYYRIK-NH2 with enhanced specific binding affinity and high antagonist activity for nociceptin ORL1 receptor, Bioorg. Med. Chem. 22 (2014) 5721-5726, http://dx. doi.org/10.1016/j.bmc.2014.09.049.

[52] J. Li, K. Isozaki, K. Okada, A. Matsushima, T. Nose, T. Costa, Y. Shimohigashi, Designed modification of partial agonist of ORL1 nociceptin receptor for conversion into highly potent antagonist, Bioorg. Med. Chem. 16 (2008) 2635-2644, http://dx. doi.org/10.1016/j.bmc.2007.11.043.
[53] a R. Jacobson, a R. Gintzler, L.M. Sayre, Minimum-structure enkephalin analogues incorporating L-tyrosine, $\mathrm{D}$ (or L)-phenylalanine, and a diamine spacer, J. Med. Chem. 32 (1989) 1708-1717, http://dx.doi.org/10.1021/jm00128a007.

[54] A.Z. Rónai, I. Berzétei, S. Bajusz, Differentiation between opioid peptides by naltrexone, Eur. J. Pharmacol. 45 (1977) 393-394, http://dx.doi.org/10.1016/00142999(77)90281-3.

[55] A.Z. Rónai, J.I. Székely, I. Berzétei, E. Miglécz, S. Bajusz, Tetrapeptide-amide analogues of enkephalin: the role of C-terminus in determining the character of opioid activity, Biochem. Biophys. Res. Commun. 91 (1979) 1239-1249, http://dx. doi.org/10.1016/0006-291X(79)91200-2.

[56] J.A. Lord, A.A. Waterfield, J. Hughes, H.W. Kosterlitz, Endogenous opioid peptides: multiple agonists and receptors, Nature 267 (1977) 495-499 (Accessed 13 March 2017), http://www.ncbi.nlm.nih.gov/pubmed/195217.

[57] M. Al-Khrasani, G. Orosz, L. Kocsis, V. Farkas, A. Magyar, I. Lengyel, S. Benyhe, A. Borsodi, A.Z. Rónai, Receptor constants for endomorphin-1 and endomorphin-1ol indicate differences in efficacy and receptor occupancy, Eur. J. Pharmacol. 421 (2001) 61-67 (Accessed 13 March 2017), http://www.ncbi.nlm.nih.gov/pubmed/ 11408050.

[58] R.-J. Lohman, R.S. Harrison, G. Ruiz-Gómez, H.N. Hoang, N.E. Shepherd, S. Chow, T.A. Hill, P.K. Madala, D.P. Fairlie, Helix-constrained nociceptin peptides are potent agonists and antagonists of ORL-1 and nociception, Vitam. Horm. 97 (2015) 1-55, http://dx.doi.org/10.1016/bs.vh.2014.10.001. 
Erdei AI, Borbely A, Magyar A, Szücs E, Ötvös F, Gombos D, Al-Khrasani M, Stefanucci A,Dimmito M.P, Luisi G, Mollica A, Benyhe S. Biochemical and pharmacological investigation of novel nociceptin/OFQ analogues and N/OFQ-RYYRIK hybrid peptides. PEPTIDES (2018). 


\title{
Biochemical and pharmacological investigation of novel nociceptin/OFQ analogues and N/OFQ-RYYRIK hybrid peptides
}

\author{
Anna I. Erdei ${ }^{\mathrm{a}, \mathrm{e}}$, Adina Borbély ${ }^{\mathrm{b}}$, Anna Magyar ${ }^{\mathrm{b}}$, Edina Szúics ${ }^{\mathrm{a}, \mathrm{e}}$, Ferenc Ötvös ${ }^{\mathrm{a}}$, Dávid Gombos ${ }^{\mathrm{a}}$, \\ Mahmoud Al-Khrasani ${ }^{\mathrm{c}}$, Azzurra Stefanucci ${ }^{\mathrm{d}}$, Marilisa Pia Dimmito ${ }^{\mathrm{d}}$, Grazia Luisi ${ }^{\mathrm{d}}$, \\ Adriano Mollica ${ }^{\mathrm{d}}$, Sándor Benyhe $\mathrm{a}^{\mathrm{a}, *}$ \\ ${ }^{a}$ Institute of Biochemistry, Biological Research Center, Hungarian Academy of Sciences, H-6726 Szeged, Temesvári krt. 62., Hungary \\ ${ }^{\mathrm{b}}$ MTA-ELTE Research Group of Peptide Chemistry, Hungarian Academy of Sciences, Eötvös Loránd University, H-1117, Budapest, Pázmány Péter sétány 1/A, Hungary \\ ${ }^{\mathrm{c}}$ Department of Pharmacology and Pharmacotherapy, Semmelweis University, H-1445 Budapest, Nagyvárad tér 4., Hungary \\ ${ }^{\mathrm{d}}$ Dipartimento di Farmacia, Università degli Studi "G. d'Annunzio" di Chieti-Pescara, Via dei Vestini 31, Chieti, 66100, Italy \\ ${ }^{\mathrm{e}}$ Doctoral School of Theoretical Medicine, University of Szeged, Faculty of Medicine, Szeged, Hungary
}

\section{A R T I C L E I N F O}

\section{Keywords:}

Opioid receptor

Nociceptin

Hybrid peptides

Receptor binding

G-protein activation

Mouse vas deferens bioassay

Bivalent ligands

\begin{abstract}
A B S T R A C T
The endogenous ligand nociceptin (N/OFQ) and a positively charged synthetic peptide RYYRIK are both selective for the nociceptin opioid receptor (NOPr). Despite their structural dissimilarity, N/OFQ and RYYRIK compete for the same binding site of NOP receptor possessing full and partial agonistic character, respectively. In the view of the message-address concept, hybrid peptide constructs were probed for the NOP receptor combining different regions of N/OFQ and RYYRIK related peptide sequences. Nine novel nociceptin- or Ac- $\mathrm{RYYRIK-NH}_{2}$ peptide variants or hybrid peptides were synthesized and characterized. Peptides P2 and P8 contain fragments of

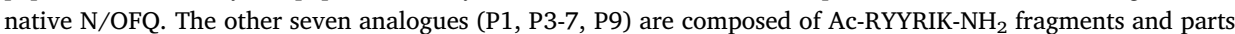
of the original nociceptin sequence. The analogues were characterized in receptor binding assays and G-protein activation experiments on rat brain membranes, as well as by electrically stimulated mouse vas deferens bioassay. In receptor binding assays ligands $\mathrm{P} 2, \mathrm{P} 4, \mathrm{P} 6\left(\mathrm{~K}_{\mathrm{i}} 0.37 \mathrm{nM}\right)$ and $\mathrm{P} 7$ showed higher affinity $\left(\mathrm{K}_{\mathrm{i}} 0.65 \mathrm{nM}, 0.6 \mathrm{nM}\right.$, $0.37 \mathrm{nM}$ and $0.44 \mathrm{nM}$, respectively) for NOP receptor than their parent compounds N/OFQ $\left(\mathrm{K}_{\mathrm{i}} 2.8 \mathrm{nM}\right)$ or AcRYYRIK-NH $\mathrm{N}_{2}\left(\mathrm{~K}_{\mathrm{i}} 4.2 \mathrm{nM}\right)$. In $\left[{ }^{35} \mathrm{~S}\right] \mathrm{GTP} \gamma \mathrm{S}$ binding experiments P2 and P3 behaved as full agonists. The other variants exhibited partial agonist properties characterized by submaximal stimulatory effects. In mouse vas deferens bioassay only P2 showed agonist activity. P4, P5, P6 inhibited the biological activity of N/OFQ more effectively than the NOP receptor selective antagonist JTC-801. In summary, hybrid peptides P4, P5 and P6 proved to be NOP receptor partial agonists even antagonists, while P2 peptide retained the full agonist property.
\end{abstract}

\section{Introduction}

The NOP receptor, belonging to the superfamily of G-protein-coupled receptors, was discovered in 1994, after the cloning of opioid-like orphan receptors $[1,2]$. It is well known that the N/OFQ-NOP receptor system is widely distributed throughout the nervous system and is involved in the modulation of numerous biological functions, such as pain, depression, reward, learning and memory, food intake, cardiovascular and kidney functions [3]. This multifunctionality of the $\mathrm{N} /$ OFQ-NOP receptor system makes NOP receptor a pharmacologically important target. NOP receptor agonists, antagonists and partial agonists may have broad therapeutic potential for treating several disorders. Agonists could be useful for treating drug addiction, anxiety, stress, cough and anorexia. Antagonists might be preferable for treating various pain states, depression and Parkinson's disease. Partial agonists that behave as antagonists in the presence of a pure agonist are able to induce water diuresis [3].

The natural endopeptide ligand of NOP receptor is the heptadecapeptide nociceptin or N/OFQ (FGGFTGARKSARKLANQ) [4-6]. The NOP receptor displays high homology with classical opioid receptors (MOP, DOP and KOP receptors), even though it is not able to bind to traditional opioid ligands and is not sensitive to naloxone in binding assays [2,7]. Being an endogenous ligand, N/OFQ binds to the NOP receptor with high affinity and activates it with good efficacy in biochemical experiments. Pharmacological properties of the heptadecapeptide N/OFQ are more complex, because pronociceptive and

\footnotetext{
* Corresponding author.

E-mail address: benyhe@brc.hu (S. Benyhe).
} 
antinociceptive effects were also described. N/OFQ was originally thought to increase a painful stimulus since intracerebroventricular (i.c.v.) injection of this peptide led to a decrease in tail-flick and hotplate latency in mice. Further studies suggested that N/OFQ blocks opiate analgesia when administered i.c.v. but potentiates opiate analgesia and has antinociceptive activity when administered intrathecally [7]. The nociceptin ligand shows some homology with endogenous opioid peptides particularly dynorphin A, which is a KOP receptor selective agonist $[8,9]$. However, N/OFQ shows poor affinity for classical opioid receptors, which is attributed to its $N$-terminal residue Phe (instead of Tyr) [3]. This feature makes nociceptin highly selective for the NOP receptor over other opioid receptors.

Therefore, structure-activity relationship (SAR) studies were performed on N/OFQ to identify the key chemical modifications of its sequence to enhance its potency, metabolic stability, yet modulate its agonist efficacy, which could lead to the development of effective pharmacophores $[3,10]$. These SAR studies revealed that the main pharmacological features of N/OFQ are retained in the N/OFQ (1-13) fragment and the role of the C-terminal tetrapeptide region (14-17) is negligible.

Besides extensive studies of N/OFQ, screening a hexapeptide combinatorial library led to the identification of several positively hexapeptides with high affinity for the NOP receptor [11], of which AcRYYRIK-NH2, Ac-RYYRWK- NH2, Ac-RYYRWR-NH2, Ac-RYYLWR-NH2 and Ac-RYYKWK-NH2 were investigated in further in vitro studies. Although these Dooley's hexapeptides substantially differ in their sequence from nociceptin, they are also highly selective for the NOP receptor over the other opioid receptors behaving as partial agonists, antagonists or full agonist, depending on the tissue preparation or experimental conditions [12,13].

Comparison of the sequences of N/OFQ and the hexapeptides points to a single common feature, namely all four basic residues of N/OFQ are comprised within a six residue long region (8-13) which, however, is far from the putative message region. Based on the fact that the hexapeptides and N/OFQ show very similar affinity and selectivity profiles, it seems obvious that these hexapeptides contain the message and address information within a significantly shorter fragment.

It is known that the $N$-terminal sequence FGGF of N/OFQ binds deep in the transmembrane binding pocket of the NOP receptor [14], while the positively charged N/OFQ (8-13) binds the negatively charged ECL2 domain of NOP receptor [14], which has a critical role in receptor activation [14,15]. Molecular dynamics simulations suggest that N/OFQ (14-17) does not interact with the NOP receptor [15]. This may be explained by the SAR studies, which show that the shortest active fragment of nociceptin is N/OFQ (1-13) [16,17].

It has been reported that Dooley's hexapeptides such as Ac-RYYRIK$\mathrm{NH}_{2}$ competitively inhibited N/OFQ binding to the NOP receptor [18] and therefore their binding sites may overlap [19]. Since Ac-RYYRIK$\mathrm{NH}_{2}$ contains basic amino acid residues, similarly to N/OFQ (8-13), it was assumed that this hexapeptide also bound to the acidic ECL2 [20]. However, Kawano et al found that Ac-RYYRIK- $\mathrm{NH}_{2}$ interacted with the receptor site to which nociception (1-7) or -(14-17) binds [19]. Akuzawa et al obtained similar results: they found that Ac-RYYRIK- $\mathrm{NH}_{2}$ and nociception (1-4) shared the NOP receptor binding pocket [21]. Bes and Meunier performed photoaffinity labeling studies using the photolabile Dooley's hexapeptide Ac-RYYRWR- $\mathrm{NH}_{2}$. Their results suggested that, contrary to the previously mentioned two hypotheses, these basic hexapeptides could bind to the TM2 domain of NOP receptor, so N/OFQ and Ac-RYYRYK- $\mathrm{NH}_{2}$ did not share the binding sites on NOP receptor [20].

In this study nine new nociceptin analogues were constructed. Group 1 of these variants (consisting of 2 peptides denoted by P2 and P8) contained fragments of the natural nociceptin peptide, while Group 2 (7 ligands denoted by P1, P3, P4-7 and P9) included those analogues which were composed of Ac-RYYRIK and parts of the native nociceptin sequence. The hexapeptide motif RYYRIK was present at the $\mathrm{N}$ - terminus, the middle (P3) or the C-terminus (P9) of these chimeric peptide ligands.

We hypothesized that the hybrid peptides in Group 2, which contain fragments of the N/OFQ sequence and RYYRIK may share the binding sites with nociceptin on the NOP receptor and bind to it with greater affinity than their parent peptides. Furthermore, we assumed that those variants in Group 2 which carry Ac-RYYRIK at the $N$-terminus (P1, P4P7) could competitively inhibit N/OFQ in a highly selective manner.

This paper is devoted to see whether the binding and receptor activation of the NOP receptor by novel synthetic peptide analoguess can be explained by modular interactions by combining the message and address regions of structurally distant peptide ligands. Although an experimental design with all permutations of the supposed domains in NOP (plus RYYRIK and C-terminal amidation added) would supposedly serve more satisfactory answer using a fairly high number of peptides, present paper is addressing only certain key points in the modular building of active N/OFQ analogs. It has been described that the truncated $\mathrm{N} / \mathrm{OFQ}(1-13)-\mathrm{NH}_{2}$ showed similar affinity and efficacy as the unmodified N/OFQ, which was explained as a consequence of the $C$ terminal amidation [22]. Therefore, we decided to amidate the $C$-terminus of some analogues (P1-4, P9), to test our hypothesis that this modification improves affinity and potency of these hybrid peptides. The present study aimed to characterize the pharmacological properties (affinity, selectivity and receptor preference) of the nine nociceptin peptide analogues in receptor binding and functional $\left[{ }^{35} \mathrm{~S}\right] \mathrm{GTP} \gamma \mathrm{S}$ binding assays, as well as in mouse vas deferens bioassay. It is expected that hybrid sequences started with the Dooley's motif (P1 and P4-7) will rather be possessing either partial agonist or antagonist properties.

\section{Materials and methods}

\subsection{Radiochemicals}

$\left[{ }^{3} \mathrm{H}\right]$ nociceptin (specific activity: $115.5 \mathrm{Ci} / \mathrm{mmol}$ ) was purchased from PerkinElmer (Boston, USA). [ $\left.{ }^{3} \mathrm{H}\right] \mathrm{HS}-665$ ([23]; s.a: $13.1 \mathrm{Ci} /$ mmol), [ $\left.{ }^{3} \mathrm{H}\right]$ DAMGO (s.a: $38.8 \mathrm{Ci} / \mathrm{mmol}$ ) and $\left[{ }^{3} \mathrm{H}\right] \mathrm{Ile}{ }^{5,6}$ Deltorphin II ([24]; s.a: $19.6 \mathrm{Ci} / \mathrm{mmol}$ ) were radiolabeled by the Laboratory of Chemical Biology group in BRC (Szeged, Hungary). Guanosine $5^{\prime}-O-\gamma$-thio$\left[{ }^{35} \mathrm{~S}\right]$-triphosphate $\left(\left[{ }^{35} \mathrm{~S}\right] \mathrm{GTP} \gamma \mathrm{S}\right.$; s.a: $\left.1000 \mathrm{Ci} / \mathrm{mmol}\right)$ was purchased from Hartmann Analytic (Braunschweig, Germany).

\subsection{Peptides}

Nociceptin (1-17) and Tyr-D-Ala-Gly-(NMe)Phe-Gly-ol (DAMGO) were obtained from Bachem Holding AG (Bubendorf, Switzerland). [D$\mathrm{Ala}^{2}, \mathrm{D}-\mathrm{Leu}^{5}$ ]enkephalin (DADLE) was purchased from Sigma-Aldrich (Budapest, Hungary). [Ile ${ }^{5,6}$ ]-Deltorphin II (IleDelt II) was synthetized in the laboratory of the Chemical Biology group of the Biological Research Center (BRC), Szeged, Hungary. The novel peptides were prepared as follows: All solvents and coupling reagents were purchased from VWR (Radnor, PN, USA). Fmoc amino acids and Fmoc-Rink-amide MBHA resin $(0.68 \mathrm{mmol} / \mathrm{g})$ were purchased from Chem-Impex (Wood Dale, IL, USA) and IRIS Biotech GmbH (Marktredwitz, DH, Germany). Amino acids were used with orthogonal protecting groups as follows: OtBu for Tyr, Thr, Ser side chains, Pbf protecting group for Arg side chain, Boc protecting group for Lys side chain and Trt for Asn and Gln side chains [21]. The peptides were synthesized by Fmoc-SPPS (standard solid phase peptide synthesis) using TBTU/HOBt/DIPEA for coupling reactions and piperidine 20\% solution in DMF for Fmoc group deprotection as previously described [22,23].

Purification of the crude peptides were carried out by RP-HPLC using a Kromasil 100-5C18, $4.6 \mathrm{~mm}$ x $250 \mathrm{~mm}, 5 \mu \mathrm{m}$ column, at a flow rate of $4.0 \mathrm{~mL} / \mathrm{min}$ and a linear gradient of $\mathrm{H}_{2} \mathrm{O} /$ acetonitrile/0.1\% TFA ranging from $5 \%$ acetonitrile to $95 \%$ acetonitrile in $35 \mathrm{~min}$.

The purity of all final TFA salts was confirmed by analytical RPHPLC (C18-4.6 mm X $250 \mathrm{~mm}, 5 \mu \mathrm{m}$ column) at a flow rate of $1 \mathrm{~mL} /$ 
min, using eluent as a gradient of $\mathrm{H}_{2} \mathrm{O}$ /acetonitrile $0.1 \%$ TFA ranging from $15 \%$ acetonitrile to $45 \%$ acetonitrile in $12 \mathrm{~min}$ and was found to be $\geq 95 \%$. The identity of final peptides was confirmed by ESI-LRMS. The mass spectrometry (MS) system consisted of an API 150EX, (Applied Biosystems) ion trap mass spectrometer (Foster City, CA) equipped with an electrospray ionization (ESI) source. The capillary temperature was set to $300{ }^{\circ} \mathrm{C}$ and the spray voltage to $4.00 \mathrm{kV}$. The fluid was nebulized using nitrogen $\left(\mathrm{N}_{2}\right)$ as the sheath and auxiliary.

\subsection{Other chemicals}

Tris-HCl, $\mathrm{MgCl}_{2} \times 6 \mathrm{H}_{2} \mathrm{O}, \mathrm{NaCl}$, EGTA and GTP analogue GTP $\gamma \mathrm{S}$ were purchased from Sigma-Aldrich (Budapest, Hungary). SB-612 and JTC80 were purchased from Tocris Bioscience (Bristol, UK). Naloxone was kindly provided by the company Endo Laboratories DuPont de Nemours (Wilmington, DE, USA). The UltimaGold ${ }^{\mathrm{TM}}$ MV aqueous scintillation cocktail was purchased from PerkinElmer (Boston, USA).

\subsection{Animals}

In in vitro receptor binding experiments we applied inbred Wistar rats (250-300 g body weight) which were housed in the local animal house of BRC (Szeged, Hungary), and male guinea pigs ( $\sim 700 \mathrm{~g}$ body weight, LAL/HA/BR strain) which originated from LAB-ÁLL Bt. (Budapest, Hungary). In mouse vas deferens bioassay we used NMRI mice (35-45g). Mice were purchased from Toxicoop (Budapest, Hungary) and were housed in the local animal house of the Department of Pharmacology and Pharmacotherapy of the Semmelweis University (Budapest, Hungary).

All animals were kept in groups of five in a temperature controlled room $\left(21-24^{\circ} \mathrm{C}\right)$ under a 12:12 light and dark cycle, allowed free access to tap water and standard rodent food until the time of sacrifice. The animals were handled humanely, in complete accordance with the European directive 2010/63/EU on the protection of animals used for scientific purposes and the Hungarian Act for the Protection of Animals in Research (XXVIII.tv. 32.§). Both the number of animals and their suffering were minimized throughout our experiments.

\section{Membrane preparation}

\subsection{Preparation of rat brain membranes}

Throughout the in vitro receptor binding experiments we applied rat and guinea pig brain membranes. The membrane fractions were prepared according to the method described previously [24]. Briefly, the animals were decapitated and the brains were quickly removed. The brains without the cerebellum were homogenized in ice-cold $50 \mathrm{mM}$ Tris-HCl buffer (pH 7.4) using a Teflon-glass homogenizer. The filtered homogenates were centrifuged at $40,000 \times \mathrm{g}$ for $20 \mathrm{~min}$ at $4^{\circ} \mathrm{C}$. Afterwards the pellet was resuspended in $50 \mathrm{mM}$ Tris- $\mathrm{HCl}$ (pH 7.4) buffer and incubated at $37{ }^{\circ} \mathrm{C}$ for $30 \mathrm{~min}$ in a shaking water-bath. The centrifugation step was repeated after the incubation. The final pellet was suspended in $50 \mathrm{mM}$ Tris- $\mathrm{HCl}(\mathrm{pH}$ 7.4) buffer containing $0.32 \mathrm{M}$ sucrose and stored at $-85^{\circ} \mathrm{C}$ until further use.

\subsection{Radioligand binding competition experiments}

Aliquots of frozen rat and guinea pig brain membrane homogenates $\left(40,000 \mathrm{x} \mathrm{g}, 20 \mathrm{~min}, 4^{\circ} \mathrm{C}\right)$ were centrifuged and washed to remove sucrose. The pellets were suspended in $50 \mathrm{mM}$ Tris- $\mathrm{HCl}$ buffer ( $\mathrm{pH} 7.4$ ) with up to $0.3-0.5 \mathrm{mg} / \mathrm{ml}$ of protein. Membranes were incubated with $1 \mathrm{nM}$ of the radioligands and increasing concentrations $\left(10^{-10}-10^{-5}\right.$ $\mathrm{M})$ of the various unlabeled peptides to be tested. Incubation conditions depended on the radioligands: for $\left[{ }^{3} \mathrm{H}\right]$ DAMGO and $\left[{ }^{3} \mathrm{H}\right]$ Ile ${ }^{5,6}$ Deltorphin II $35^{\circ} \mathrm{C}$ for $45 \mathrm{~min}$, for $\left[{ }^{3} \mathrm{H}\right] \mathrm{HS}-66530^{\circ} \mathrm{C}$ for $45 \mathrm{~min}$, and for $\left[{ }^{3} \mathrm{H}\right]$ nociceptin $30^{\circ} \mathrm{C}$ for $30 \mathrm{~min}$. Guinea pig brain was used in those experiments in which the tested ligands were investigated for KOP receptor, because it has significantly more KOP receptors than rat brain. Total binding was measured in the presence of the given radioligands, while non-specific binding was determined in the presence of $10 \mu \mathrm{M}$ of unlabeled naloxone, naltrindole, U-69,593 and nociceptin, respectively. After the incubation, the reaction was terminated by filtrating the samples through Whatman GF/C $\left(\left[{ }^{3} \mathrm{H}\right]\right.$ DAMGO, $\left[{ }^{3} \mathrm{H}\right]$ Ile ${ }^{5,6}$ Deltorphin II or GF/B ( $\left[{ }^{3} \mathrm{H}\right] \mathrm{U}-69593$ and $\left[{ }^{3} \mathrm{H}\right]$ nociceptin) glass fibre filters (GE Healthcare, Little Chalfont, UK) under vacuum (Brandel M24R Cell Harvester; Brandel Harvesters, Gaithersburg, MD). The filters were washed three times with $5 \mathrm{ml}$ ice-cold $50 \mathrm{mM}$ Tris- $\mathrm{HCl}(\mathrm{pH}$ 7.4) and then with UltimaGold MV aqueous scintillation cocktail (Perkin Elmer, Waltham, MA) to detect the radioactivity with a Packard Tricarb 2300TR LSC spectrometer. The competition binding assays were performed in duplicates and repeated at least three times.

\section{3. $\left[{ }^{35} S\right] G T P \gamma S$ binding experiments}

The functional $\left[{ }^{35} \mathrm{~S}\right] \mathrm{GTP} \gamma \mathrm{S}$ binding assays were performed as described previously [25], with slight modifications. Rat and guinea pig brain membrane fractions ( $\sim 10 \mu$ g of protein/sample) were incubated at $30{ }^{\circ} \mathrm{C}$ for $60 \mathrm{~min}$ in Tris-EGTA buffer. The buffer contained $50 \mathrm{mM}$ Tris-HCl, $1 \mathrm{mM}$ EGTA, $3 \mathrm{mM} \mathrm{MgCl} 2,100 \mathrm{mM} \mathrm{NaCl}, 30 \mu \mathrm{M}$ GDP, (pH 7.4), as well as $20 \mathrm{MBq} / 0.05 \mathrm{~cm}^{3}\left[{ }^{35} \mathrm{~S}\right] \mathrm{GTP} \gamma \mathrm{S}(0.05 \mathrm{nM})$ and increasing concentrations $\left(10^{-10}-10^{-5} \mathrm{M}\right)$ of the tested nociceptin analogues and hybrid peptides. To investigate the NOP receptor selectivity $10 \mu \mathrm{M}$ NOP receptor specific antagonist SB-612,111 was used. The final volume was $1 \mathrm{ml}$. Afterwards total binding (T) in the absence of the tested compounds was determined, and non-specific binding (NS) in the presence of $10 \mu \mathrm{M}$ unlabeled GTP $\gamma$ S to calculate basal activity.

The reaction was terminated after incubation and bound and unbound $\left[{ }^{35} \mathrm{~S}\right] \mathrm{GTP} \gamma \mathrm{S}$ were separated. The radioactivity of the filters was measured in the same way as described before.

\section{Isolated tissue assay}

\subsection{Mouse vas deferens bioassay}

Mouse vas deferens (NMRI mice, 35-45 g) was prepared as described before [26]. After the preparation vas deferens were suspended in $5 \mathrm{ml}$ organ baths containing $\mathrm{Mg}^{2+}$ free Krebs buffer $(118.1 \mathrm{mM} \mathrm{NaCl}, 25 \mathrm{mM}$ $\mathrm{NaHCO}_{3}, 4.7 \mathrm{mM} \mathrm{KCl}, 11 \mathrm{mM}$ glucose, $1.2 \mathrm{mM} \mathrm{KH}_{2} \mathrm{PO}_{4}, 1.8 \mathrm{mM} \mathrm{CaCl}_{2}$ ) and aerated with carbogen $\left(\mathrm{O}_{2}: \mathrm{CO}_{2}=95: 5\right)$ at $31^{\circ} \mathrm{C}$. The tissues were mounted between two electrodes under an initial tension of $0.1 \mathrm{~g}$. The stimulation parameters were as follows: field stimulation, pairs $(100 \mathrm{~ms}$ pulse distance) of rectangular impulses ( $1 \mathrm{~ms}$ pulse width, $9 \mathrm{~V} / \mathrm{cm}$ i.e. supramaximal intensity) were repeated by $10 \mathrm{~s}$. The muscle contractions were monitored by computer, using a data recording and the analysis system LabChart 5 (ADInstruments Pty LTD, Australia).

Before adding the first dose of agonists, $30-40 \mathrm{~min}$ equilibration was performed on the tissues under stimulation. Then the cumulative concentration-response curves of to nociceptin analogues, hybrid peptides, nociception (1-17), or the control compounds were constructed.

This method was suitable for separating peptides with agonist activity from peptides with antagonist activity. To determine the dissociation constants $(\mathrm{Ke})$ of the antagonists,

the single-dose method was used [27].

\subsection{Data analysis and terminology}

All the experiments were repeated at least 3 times and the data were expressed as means \pm standard error of mean (S.E.M.) in logarithmic form. The radioligand competition binding experiments were performed in duplicates, while the $\left[{ }^{35} \mathrm{~S}\right] \mathrm{GTP} \gamma \mathrm{S}$ binding assays were carried out in triplicates. The experimental data were analyzed and points were fitted with GraphPad Prism 6.0 (GraphPad Prism Software Inc., San 
Diego, CA, USA, www.graphpad.com) using non-linear regression. "One-site competition" was applied in the radioligand competition binding assays to determine unlabelled ligand affinity $\left(\mathrm{IC}_{50}\right)$. In the $\left[{ }^{35} \mathrm{~S}\right] \mathrm{GTP} \gamma \mathrm{S}$ binding assays the 'Sigmoid dose-response' equation was used to determine ligand potency $\left(\mathrm{EC}_{50}\right)$ and maximum G-protein efficacy $\left(E_{\max }\right)$. The curve fitting program outputs the logarithm of the standard errors of mean (S.E.M.) for $\mathrm{IC}_{50}$ and $\mathrm{EC}_{50}$ values, due to the data representation. The equilibrium inhibition constant $\left(\mathrm{K}_{\mathrm{i}}\right)$ was calculated according to the Cheng-Prusoff equation: $\mathrm{K}_{\mathrm{i}}=\mathrm{IC}_{50} /\left(1+[\mathrm{L}] / \mathrm{K}_{\mathrm{d}}\right)$ [28] where $\mathrm{IC}_{50}$ is defined as the concentration of the competitor which produces $50 \%$ displacement, and [L] designates the concentration of the labelled ligand. Basal activity was determined in $\left[{ }^{35} \mathrm{~S}\right] \mathrm{GTP} \gamma \mathrm{S}$ binding assays in the absence of receptor ligands, and was settled at $100 \%$. The data were normalized to the basal activity. Agonist potencies were expressed as $\mathrm{pEC}_{50}$. The $\mathrm{E}_{\max }$ is the maximal effect that an agonist can trigger in a given tissue or preparation. In the $\left[{ }^{35} \mathrm{~S}\right] \mathrm{GTP} \gamma \mathrm{S}$ binding assay $\mathrm{E}_{\max }$ of agonists represents the maximal stimulation over the basal and it is expressed in \%.

After the analysis of experimental data from the MVD bioassay, $\mathrm{EC}_{50}$ were determined from individual logarithmic concentration-response curves. The equilibrium dissociation constant of antagonists $\left(\mathrm{K}_{\mathrm{e}}\right)$ was calculated using the single-dose method [27]. $\mathrm{K}_{\mathrm{e}}$ values were calculated with the following formula: $\mathrm{K}_{\mathrm{e}}=$ concentration of antagonist/[dose ratio - 1] [29]. Unpaired $t$-test with two-tailed p-value was used to see the differences between the two data sets, while for three or more data sets one-way ANOVA with Tukey's post hoc test was performed to determine statistical significance. Significance was accepted at the $\mathrm{p}<0.05$ level.

\section{Results}

\subsection{Receptor binding assays}

The sequences of the newly synthesized and characterized nociceptin analogues and nociceptin-RYYRIK hybrid peptides are summarized in Table 1, sorted into two groups: Group 1 consists of 2 ligands denoted as P2 and P8, which do not contain the RYYRIK motif, while Group 2 is comprised of 7 peptides denoted as P1, P3-7 and P9.

In order to determine the NOP receptor binding affinity of the novel peptides radioligand competition binding assays were carried out with $\left[{ }^{3} \mathrm{H}\right]$ nociceptin on rat brain membranes. For control their parent compounds (nociceptin and Ac-RYYRIK- $\mathrm{NH}_{2}$ ) were also examined.

As shown in Fig. $1 \mathrm{AB}$ and Table 2, peptides P1-P7 competed more effectively for NOP receptor than P8 or P9, which showed negligible affinity towards NOP receptor.

Surprisingly, P3 also showed low affinity in spite of FGGF being present at its $N$-terminal. On the other hand, P1, P2, P4, P6 and P7

Table 1

List of fused hybrid peptides and their parent compounds with abbreviated names and sequences.

\begin{tabular}{lll}
\hline Name/code & Length & Sequence \\
\hline $\begin{array}{l}\text { Parent peptides } \\
\text { Nociceptin, N/OFQ }\end{array}$ & 17 & \\
$\begin{array}{l}\text { Dooley's peptide } \\
\text { Group 1 (without RYYRIK) }\end{array}$ & 6 & H-FGGFTGARKSARKLANQ-OH \\
P2 & 17 & Ac-RYYRIK- $\mathrm{NH}_{2}$ \\
P8 & 11 & H-FGGFTSARKGARKLANQ-NH \\
Group 2 (containing RYYRIK) & & H-FGGFGGGFGGF-NH \\
P1 & 14 & \\
P3 & 18 & Ac-RYYRIKGARKLANQ-NH \\
P4 & 14 & H-FGGFRYYRIKSARKLANQ-NH \\
P5 & 14 & Ac-RYYRIKSARKLANQ-NH \\
P6 & 18 & Ac-RYYRIKSARKLANQ-OH \\
P7 & 14 & Ac-RYYRIKGARKSARKLANQ-OH \\
P9 & 13 & Ac-RYYRIKGARKSARK-OH \\
& & H-FGGFGGGRYYRIK-NH \\
\end{tabular}

displayed higher affinity to NOP receptor compared to the parent compounds. Although P2 differs from nociceptin in that it contains $\mathrm{Ser}^{6}$ instead of $\mathrm{Gly}^{6}$, and $\mathrm{Gly}^{10}$ instead of $\mathrm{Ser}^{10}$, we observed a remarkable affinity $\left(\mathrm{K}_{\mathrm{i}}=0.65\right)$ against $\left[{ }^{3} \mathrm{H}\right]$ nociceptin.

The chimeric peptides possessing Ac-RYYRIK N-terminal were tested for KOP, MOP and DOP to reveal selectivity within the opioid receptor family. The results showed that none of the nociceptin-RYYRIK hybrid peptides displayed DOP receptor affinity (data not shown). However, $\left[{ }^{3} \mathrm{H}\right]$ DAMGO was almost fully displaced from its receptor by P4 in higher concentrations. P1 and P7 showed relatively high affinity in the MOP receptor binding ( $\mathrm{K}_{\mathrm{i}}=13$ and $209 \mathrm{nM}$ ) (data not shown).

In competition binding assays performed with $\left[{ }^{3} \mathrm{H}\right] \mathrm{HS} 665$, P4, P6 and P7 compounds fully displaced $\left[{ }^{3} \mathrm{H}\right] \mathrm{HS} 665$ binding, however the inhibition was in the micromolar concentration range (data not shown).

\section{2. $\left[{ }^{35} S\right] G T P \gamma S$ binding experiments}

$\left[{ }^{35} \mathrm{~S}\right] \mathrm{GTP} \gamma \mathrm{S}$ binding experiments were performed on rat brain membranes to determine the potency $\left(\mathrm{pEC}_{50}\right)$ and efficacy $\left(\mathrm{E}_{\max }\right)$ of the nociceptin analogues and nociceptin-RYYRIK hybrid peptides. The test compounds were compared with their parent compounds, nociceptin, and Ac-RYYRIK-NH $\mathrm{N}_{2}$.

As it can be seen in Table 3 all the peptides moderately stimulated the monitored G-protein except for P2 and P3. While P1, P4-P9 indicated partial agonist properties, P2 and P3 exhibited full agonist activity similar to nociceptin ( $E_{\max }: 157 \%, 152 \%$ and $148 \%$ for P2, P3 and nociceptin, respectively) (Fig. 2).

To reverse or inhibit the G-protein stimulatory effect of the test compounds, we applied NOP receptor specific antagonist SB612.111 in $10 \mu \mathrm{M}$ concentrations (Fig.3). The stimulating effects of P2 and P3 were significantly antagonized by SB612.111, which confirms that NOP receptor is involved in mediating the effects of these peptides.

\subsection{Mouse vas deferens bioassay}

The aim of the mouse vas deferens bioassay was the clarification the agonist or antagonist activity of the nociceptin analogues and nociceptin-RYYRIK hybrid peptides. As a first step we set out their ability of twitch response inhibition to electrical field stimulation without a NOP receptor antagonist to determine their agonistic activity. As detailed in Table 4, the tested peptides showed slight inhibition only at high concentrations (i.e., $10 \mu \mathrm{M}$ ) even in the case of P2. Although P2 displayed high affinity $\left(\mathrm{K}_{\mathrm{i}}=0.65\right)$ for NOP receptor in radioligand competition binding assays and high efficacy (157\%) in $\left[{ }^{35} \mathrm{~S}\right] \mathrm{GTP} \gamma \mathrm{S}$ binding experiments, we only observed weak affinity for P2 (426 nM) in comparison with nociceptin $(62.4 \mathrm{nM})$ in mouse vas deferens bioassay. After characterizing the agonist activity of the tested peptides, we investigated their antagonist activity in the presence of nociceptin. The affinities of antagonists $\left(\mathrm{K}_{\mathrm{e}}\right)$ are summarized in Table 4. P5 $\left(\mathrm{K}_{\mathrm{e}}=136 \mathrm{nM}, \mathrm{n}=9\right), \mathrm{P} 6\left(\mathrm{~K}_{\mathrm{e}}=166 \mathrm{nM}, \mathrm{n}=6\right)$ and $\mathrm{P} 4\left(\mathrm{~K}_{\mathrm{e}}=258 \mathrm{nM}\right.$, $\mathrm{n}=5$ ) could antagonize the effect of nociceptin more effectively than the control antagonist JTC- $801\left(\mathrm{~K}_{\mathrm{e}}=480 \mathrm{nM}, \mathrm{n}=11\right)$, which displayed a negligible partial agonist activity in high concentration $(10 \mu \mathrm{M})$ similar to P4, P5, P6 and P7.

\section{Discussion}

The single natural ligand of the G-protein coupled NOP receptor, nociceptin (N/OFQ, FGGFTGARKSARKLANQ) was identified in 1995 via reverse pharmacology $[3,4]$. N/OFQ together with its NOP receptor forms the N/OFQ-NOP system, which has been intensively studied over the past 20 years. The investigations have revealed that both NOP receptor agonists and antagonists have significant therapeutic potential. Structure-activity relationship (SAR) studies were performed to identify those amino acids and/or sequences in the N/OFQ sequence that are essential for binding to and activation of NOP receptor. 

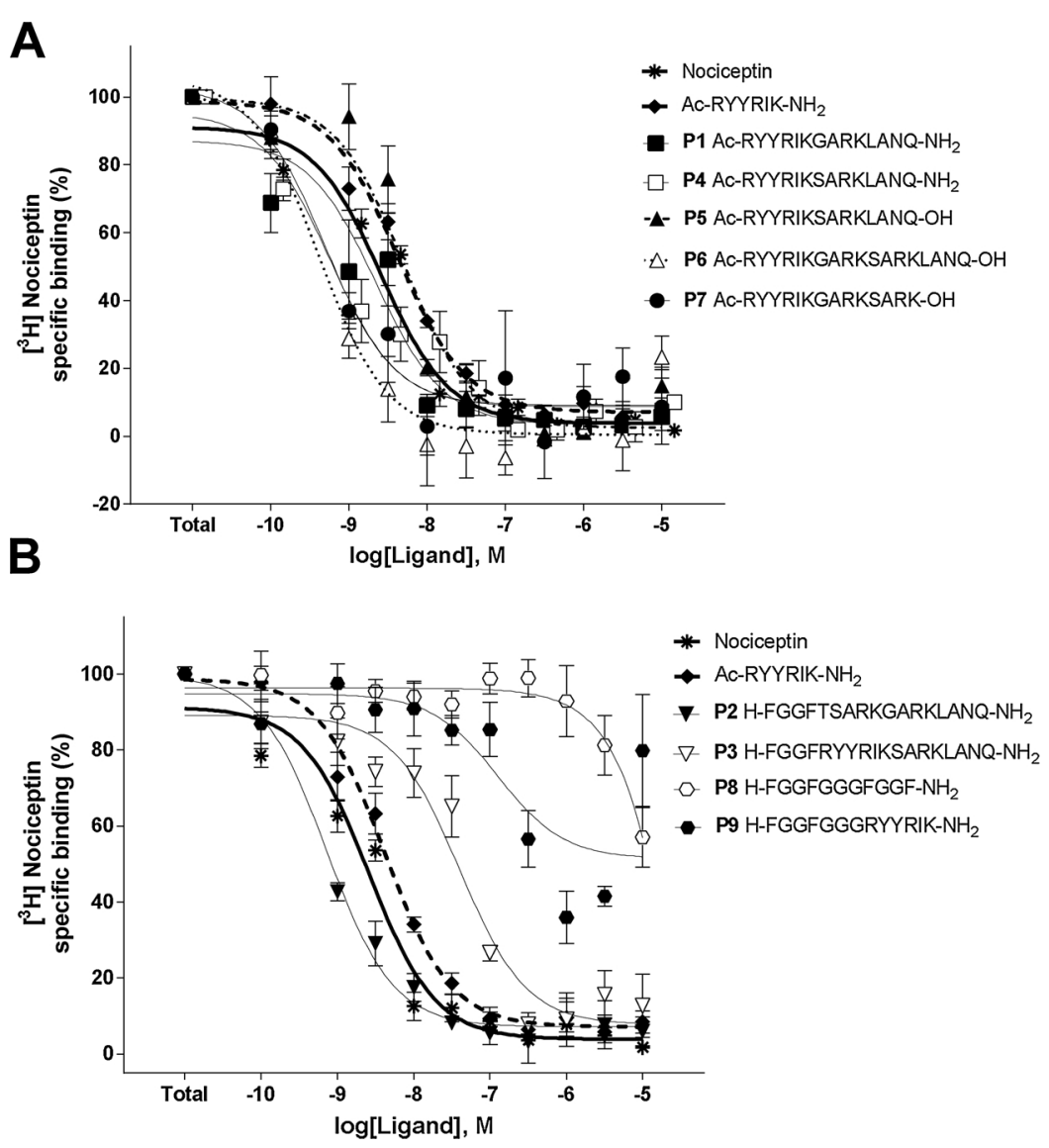

Fig. 1. NOP receptor binding affinity of nociceptin hybrid peptides (A and B) compared to nociceptin and Ac-RYYRIK-NH $\mathrm{H}_{2}$ in $\left[{ }^{3} \mathrm{H}\right]$ nociceptin competition binding assays in rat brain membrane homogenates. Figures represent the specific binding of $\left[{ }^{3} \mathrm{H}\right]$ nociceptin in percentage in the presence of increasing concentrations $\left(10^{-10}-10^{-5} \mathrm{M}\right)$ of the indicated unlabeled ligands. The level of total specific binding was defined as $100 \%$ and points represent means \pm S.E.M. for at least three experiments performed in duplicates.
Furthermore, such chemical modifications were investigated that could increase potency, metabolic stability and agonist efficacy, or alter the agonist and antagonist properties.

In this study 9 novel nociceptin variants were synthesized and characterized. Group 1 of these variants comprises peptides P2 and P8, which contain fragments of the natural nociceptin peptide. Group 2 includes those analogues (P1, P3, P4, P5, P6, P7, P9) which are composed of the Ac-RYYRIK- $\mathrm{NH}_{2}$ hexapeptide and parts of the original nociceptin sequence. RYYRIK could be present at the beginning ( $N$ terminal), the middle or the end ( $C$-terminal) of these synthetic peptides. We chose Ac-RYYRIK- $\mathrm{NH}_{2}$ because it acted as an antagonist in the presence of nociceptin and inhibited its biological activity.

Initially it was reported that transmembrane helix 2 of the NOP receptor takes part in the recognition of Ac-RYYRIK- $\mathrm{NH}_{2}$, but other molecular modelling and docking studies found that Ac-RYYRIK- $\mathrm{NH}_{2}$ interacts with those sits of NOP receptor such as N/OFQ, which implies that the binding sites of N/OFQ and RYYRIK may overlap. One of the implications of this result is that hybrid peptides from the combination of RYYRIK and parts of nociceptin may bind to NOP receptor with greater affinity than nociceptin itself.

The 9 peptides were first studied in receptor binding assays. $\mathrm{P} 8(\mathrm{H}-$ FGGFGGGFGGF-NH ${ }_{2}$ ) and P2 (H-FGGFTSARKGARKLANQ- $\mathrm{NH}_{2}$ ) belonging to Group 1 had different affinities for the NOP receptor. While P8 was practically unable to displace $\left[{ }^{3} \mathrm{H}\right]$ nociceptin, the $\mathrm{K}_{\mathrm{i}}$ value of $\mathrm{P} 2$ was lower than that of nociceptin. By synthesizing P8 our aim was to investigate whether we could create a high affinity peptide resembling

Table 2

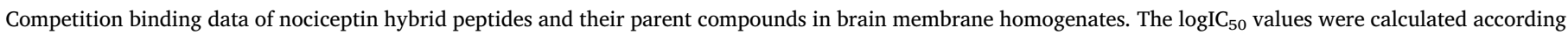
to the competition binding curves.

\begin{tabular}{|c|c|c|c|c|}
\hline & & \multicolumn{3}{|c|}{ Affinity, pIC50 \pm S.E.M. $\left(\mathrm{K}_{\mathrm{i}}, \mathrm{nM}\right)$} \\
\hline \multicolumn{2}{|c|}{ Compounds } & {$\left[{ }^{3} \mathrm{H}\right] \mathrm{HS} 665$ (KOP receptor) } & {$\left[{ }^{3} \mathrm{H}\right]$ DAMGO (MOP receptor) } & {$\left[{ }^{3} \mathrm{H}\right]$ nociceptin (NOP receptor) } \\
\hline \multicolumn{5}{|c|}{ Parent compounds } \\
\hline \multicolumn{2}{|c|}{ Nociceptin } & $9.34 \pm 2.9(0.4)$ & $8.26 \pm 0.33(4.79)$ & $8.5 \pm 0.1(2.8)$ \\
\hline \multicolumn{2}{|c|}{ Ac-RYYRIK-NH ${ }_{2}$} & $6.22 \pm 1.1(529)$ & $7.3 \pm 3.2(24.6)$ & $8.4 \pm 2.5(4.2)$ \\
\hline \multicolumn{5}{|c|}{ Fused hybrid peptides } \\
\hline $\mathrm{P} 1$ & Ac-RYYRIKGARKLANQ- $\mathrm{NH}_{2}$ & $5.8 \pm 0.5(1482)$ & $7.6 \pm 2.2(26)$ & $8.7 \pm 0.2(2)$ \\
\hline $\mathrm{P} 2$ & H-FGGFTSARKGARKLANQ-NH ${ }_{2}$ & n.d. & n.d. & $9.1 \pm 0.1(0.65)$ \\
\hline P3 & H-FGGFRYYRIKSARKLANQ- $\mathrm{NH}_{2}$ & n.d. & n.d. & $7.4 \pm 0.12(36)$ \\
\hline $\mathrm{P} 4$ & Ac-RYYRIKSARKLANQ-NH ${ }_{2}$ & $5.6 \pm 0.2(2510)$ & $5.3 \pm 0.4(4549)$ & $9.3 \pm 0.1(0.6)$ \\
\hline P5 & Ac-RYYRIKSARKLANQ-OH & $5 \pm 0.7(9699)$ & $5.6 \pm 3.2(2432)$ & $8.3 \pm 0.1(4.44)$ \\
\hline P6 & Ac-RYYRIKGARKSARKLANQ-OH & $5.5 \pm 0.2(3202)$ & $4.9 \pm 0.7(12,120)$ & $9.4 \pm 0.2(0.37)$ \\
\hline P7 & Ac-RYYRIKGARKSARK-OH & $5.4 \pm 0.3(3998)$ & $6.4 \pm 0.4(422)$ & $9.3 \pm 0.2(0.44)$ \\
\hline P8 & H-FGGFGGGFGGF-NH ${ }_{2}$ & n.d. & n.d. & $4.2 \pm 2.2(6192)$ \\
\hline P9 & H-FGGFGGGRYYRIK-NH ${ }_{2}$ & n.d. & n.d. & $6.9 \pm 0.3(112)$ \\
\hline
\end{tabular}

n.d.: not determined. 
Table 3

The stimulation of G-protein by the nociceptin hybrid peptides and their parent compounds in $\left[{ }^{35} \mathrm{~S}\right] \mathrm{GTP} \gamma \mathrm{S}$ binding assays using rat brain membrane homogenates. The efficacy $\left(\mathrm{E}_{\max }\right)$ and ligand potency $\left(\mathrm{pEC}_{50}\right)$ values were calculated by analyzing dose-response binding curves.

\begin{tabular}{|c|c|c|c|}
\hline \multicolumn{2}{|c|}{ Peptides } & \multicolumn{2}{|l|}{ Rat brain membranes } \\
\hline & & $\begin{array}{l}\text { Potency } p \mathrm{EC}_{50} \pm \\
\text { S.E.M. }\left(\mathrm{EC}_{50}, \mathrm{nM}\right)\end{array}$ & $\begin{array}{l}\text { Efficacy \% } \mathrm{E}_{\max } \text {, } \\
\pm \text { S.E.M. }\end{array}$ \\
\hline \multicolumn{4}{|c|}{ Parent compounds } \\
\hline Noc & ceptin & $8.0 \pm 0.2(9.2)$ & $148 \pm 3.6$ \\
\hline $\begin{array}{l}\text { Ac- } \\
\text { Fus }\end{array}$ & \multicolumn{2}{|c|}{ Fused hybrid peptides } & $121 \pm 1.2$ \\
\hline $\mathrm{P} 1$ & Ac-RYYRIKGARKLANQ- $\mathrm{NH}_{2}$ & $6.6 \pm 0.5(258)$ & $127 \pm 4.6$ \\
\hline $\mathrm{P} 2$ & H-FGGFTSARKGARKLANQ-NH & $6.5 \pm 0.35(338)$ & $157 \pm 0.34$ \\
\hline P3 & H-FGGFRYYRIKSARKLANQ-NH ${ }_{2}$ & $5.85 \pm 0.28(1430)$ & $152 \pm 8.2$ \\
\hline P4 & Ac-RYYRIKSARKLANQ- $\mathrm{NH}_{2}$ & $6.9 \pm 0.41(119)$ & $119 \pm 3.65$ \\
\hline P5 & Ac-RYYRIKSARKLANQ-OH & $8.3 \pm 0.3(5.4)$ & $140 \pm 2.6$ \\
\hline P6 & Ac-RYYRIKGARKSARKLANQ-OH & $7.5 \pm 0.6(147)$ & $126 \pm 2.33$ \\
\hline P7 & Ac-RYYRIKGARKSARK-OH & $8.93 \pm 0.51(1.2)$ & $114 \pm 2.5$ \\
\hline P8 & H-FGGFGGGFGGF-NH ${ }_{2}$ & $7.4 \pm 1.2(44)$ & $123 \pm 1.02$ \\
\hline & H-FGGFGGGRYYRIK-NH ${ }_{2}$ & $8.9 \pm 1.3(1.3)$ & $119 \pm 1.01$ \\
\hline
\end{tabular}

little bit to biphalin [30]. However, the absence of the address domain resulted in a loss of binding ability probably because of the lack of some basic residues and other residues essential for binding. The sequences of P2 and N/OFQ are different, because N/OFQ contains the GARKSARK central motif, which is replaced with the SARKGARK sequence in P2, so the positions of the apolar Gly and the polar Ser have changed. A further difference is that P2 bears an amidated C-terminus. In terms of binding affinity at the NOP receptor P2 proved to be the best peptide analogue among the compounds studied. Similarly to the endogenous N/OFQ sequence, P2 exhibited a full agonist profile $\left(\mathrm{E}_{\max } 157 \%\right)$ although with lower potency in the $\left[{ }^{35} \mathrm{~S}\right] \mathrm{GTP} \gamma \mathrm{S}$ binding experiments. Beside N/OFQ, P2 was the other peptide carrying pure agonist activity in the mouse vas deferens bioassay. Taken together, despite the three modifications, the biochemical and pharmacological properties of P2 and N/OFQ remained close to each other.

The variants belonging to Group 2 (P1, P4, P5, P6 and P7) displaced $\left[{ }^{3} \mathrm{H}\right]$ nociceptin with high affinity. P4, P6 and P7 showed lower $\mathrm{K}_{\mathrm{i}}$ values than even the parent peptides, indicating increased affinities. The cause of these high affinity values may well be that these peptides combine the favorable properties of RYYRIK and N/OFQ. Kawano et al. found that RYYRIK is likely to interact with the site of NOP receptor where nociception (1-7) and nociception (14-17) are involved [19]. Experimental results show that RYYRIK binds to the N/OFQ binding site with greater affinity than the original FGGF message domain, for which the Ac-RYY residues are primarily responsible. P4, P6 and P7 also

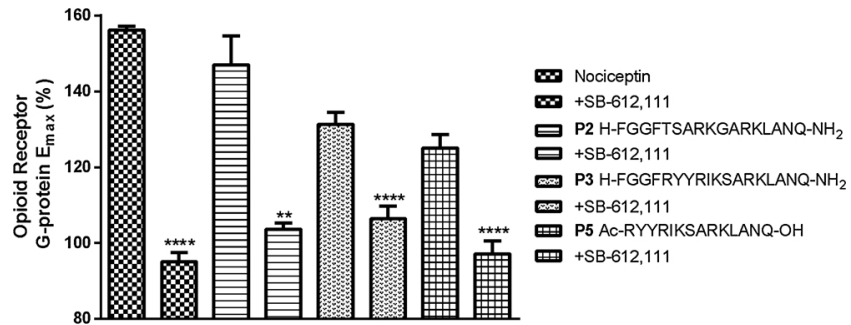

Fig. 3. Effect of a nociceptin receptor specific antagonist ligand (SB-612,111) on the G-protein activation by the nociceptin hybrid peptides. Columns shown represent mean values \pm S.E.M. SB-612,111 was used in $10 \mu \mathrm{M}$ concentration. ${ }^{* * \mathrm{p}}<0.01$ and $* * * * \mathrm{p}<0.0001$ vs. control group (unpaired $t$-test with Welch's correction, two-tailed p-value).

Table 4

Effects of the nociceptin hybrid peptides and reference compounds on the electrically stimulated mouse vas deferens.

\begin{tabular}{|c|c|c|c|}
\hline \multicolumn{2}{|c|}{ Ligands } & $\begin{array}{l}\mathrm{EC}_{50}(\mathrm{nM}) \pm \\
\text { S.E.M. }\end{array}$ & $\begin{array}{l}\mathrm{K}_{\mathrm{e}} \text { values for } \\
\text { antagonists } \pm \text { S.E.M. } \\
\text { (nM) }\end{array}$ \\
\hline \multicolumn{4}{|c|}{ Control compounds } \\
\hline Noc & ceptin & $62 \pm 4$ & n.e. \\
\hline JTC & 301 & $>100000$ & $480 \pm 72$ \\
\hline \multicolumn{4}{|c|}{ Fused hybrid peptides } \\
\hline & Ac-RYYRIKGARKLANQ- $\mathrm{NH}_{2}$ & $>10000$ & $1943 \pm 341$ \\
\hline P2 & H-FGGFTSARKGARKLANQ-NH ${ }_{2}$ & $426 \pm 76$ & n.e. \\
\hline P3 & H-FGGFRYYRIKSARKLANQ-NH ${ }_{2}$ & $>1,000,000$ & n.e. \\
\hline P4 & Ac-RYYRIKSARKLANQ- $\mathrm{NH}_{2}$ & $>100000$ & $258 \pm 61$ \\
\hline P5 & Ac-RYYRIKSARKLANQ-OH & $>1,000,000$ & $136 \pm 26$ \\
\hline P6 & Ac-RYYRIKGARKSARKLANQ-OH & $>100000$ & $166 \pm 31$ \\
\hline P7 & Ac-RYYRIKGARKSARK-OH & $>1,000,000$ & $507 \pm 79$ \\
\hline P8 & H-FGGFGGGFGGF-NH ${ }_{2}$ & $>1,000,000$ & n.e. \\
\hline & H-FGGFGGGRYYRIK-NH ${ }_{2}$ & $>1,000,000$ & n.e. \\
\hline
\end{tabular}

n.e.: no effect.

contain the nociceptin address domain. Thus, by fusion of RYYRIK and $\mathrm{N} / \mathrm{OFQ}$, we could combine their beneficial properties that may have contributed to the increase of affinity.

It is worth noting that although the amino acid sequences of P4 and P5 are identical, P4 had a 7 times greater affinity $\left(K_{i}=0.6 \mathrm{nM}\right)$ than P5 $\left(\mathrm{K}_{\mathrm{i}}=4 \mathrm{nM}\right)$ towards the NOP receptor. This is explained by the fact that the C-terminus of P4 was amidated while that of P5 was not. It has already been shown that the truncated and amidated nociceptin (1-13)$\mathrm{NH}_{2}$ exhibits a binding affinity and biological activity similar to the unmodified N/OFQ, in contrast with the deamidated truncated nociceptin (1-13), which showed poorer affinity and activity [22].
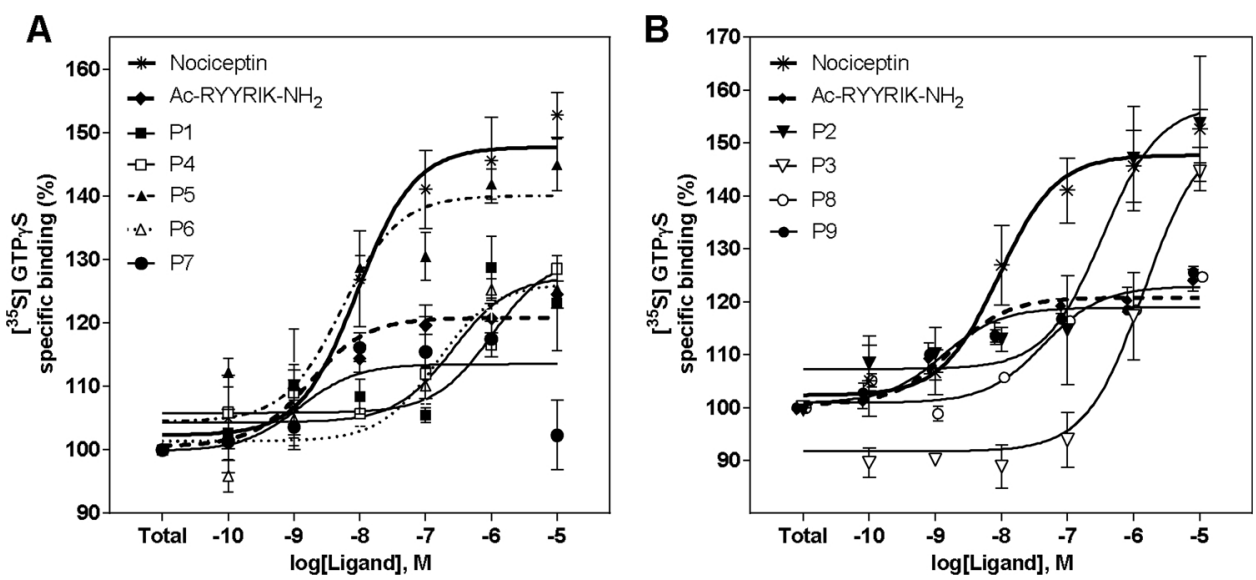

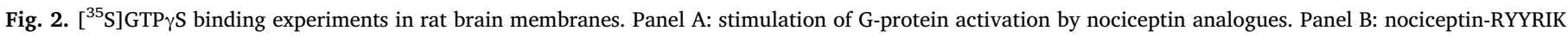
hybrid peptides induced activation of G-proteins. Points represent means \pm S.E.M. for at least three repeated experiments performed in triplicate. 
It was interesting to see that P1, which contains $\mathrm{Gly}^{7}$ instead of Ser ${ }^{7}$, displayed $30 \%$ lower $\mathrm{K}_{\mathrm{i}}$ value than $\mathrm{P} 4$ toward the NOP receptor. We assume that the apolar Gly at position 7 in the P1 ligand caused the reduction in affinity.

Although it is well known that N/OFQ and RYYRIK bind selectively to the NOP receptor, we aimed to investigate whether hybrid peptides made of highly charged RYYRIK fused with portions of N/OFQ could retain their NOP receptor selectivity, since the sequence of nociceptin peptide exhibits some similarity with the endogenous KOP receptor selective dynorphin A, e.g. message domain, and many charged amino acids in the address domain.

The results showed that the hybrid compounds had a weaker affinity for the KOP receptor than the parent compounds, so it could be excluded that hybridization of the two peptides could increase KOP receptor selectivity at the expense of NOP receptor selectivity.

In $\left[{ }^{35} \mathrm{~S}\right] \mathrm{GTP} \gamma \mathrm{S}$ assays, P8 acted as a partial agonist, while the $\mathrm{E}_{\max }$ value of P2 was higher than that of N/OFQ. It should be noted that while $\mathrm{P} 2$ had an $\mathrm{EC}_{50}$ of $338 \mathrm{nM}$ (Table 3), the $\mathrm{EC}_{50}$ value of N/OFQ is $1.9 \mathrm{nM}$, i.e. N/OFQ is over $36 \mathrm{x}$ more potent as $\mathrm{P} 2$. Of note, drugs of high efficacy have advantage in therapy, because they are able to activate NOP receptor in pathological conditions where NOP receptor reserve is low.

It has been demonstrated in case of N/OFQ that substituting the apolar - neutral Gly ${ }^{6}$ to Ala may slightly reduce the potency [10]. In the light of the fact that the potency has greatly decreased in our case, it is assumed that the replacement of the apolar amino acid with a more polar $\mathrm{Ser}^{6}$ was responsible for the large decrease.

P4, P6 and P7 showed partial agonist activity while P5 was a full agonist in the G-protein assay. Of the five variants, the best $\mathrm{EC}_{50}$ was shown by P5 $(1.2 \mathrm{nM})$ and P7 $(5.4 \mathrm{nM})$. The $\mathrm{E}_{\max }$ value of peptide P4 was $131 \pm 0.42$, while that of P5 was $140 \pm 2.6$. This contradicts our expectations, according to which $\mathrm{P} 4$ (which was amidated at the $C$ terminal end) was expected to show full agonist activity. However, P4 showed lower potency and lower $\mathrm{E}_{\max }(1028 \mathrm{nM})$ values as expected. Although P9 produced rather weak efficacy $\left(E_{\max }=119 \pm 1.01\right)$, its potency was still strong. Conversely, $\mathrm{P} 3$ produced high $\mathrm{E}_{\max }$ value with substantially weaker potency $(1430 \mathrm{nM})$. We assume that this weak effect could have arisen from the insertion of the RYYRIK hexapeptide into the nociceptin sequence. The role of the positively charged segment was addressed by peptides P3 and P9: In P9 the N-terminal FGGF (essential in N/OFQ) was connected to RYYRIK by the GGG spacer positioning the first Arg residue to the same place where N/OFQ holds the first Arg residue $\left(\mathrm{Arg}^{8}\right)$. At a time the minimal active length of 13 (in N/OFQ) was kept. The very week affinity of the resulting peptide, however, points to the importance of sequence specific interactions rather than to the position of the charged segment. P3 showed somewhat higher affinity, presumably due to the presence of the natural address region (in a more or less the correct distance from the $\mathrm{N}$ terminal) and the $\mathrm{Arg}^{8}$ residue essential in N/OFQ.

Variants that showed full agonist activity (P2, P3, P5) in the Gprotein assay, were also tested for NOP receptor selectivity. To achieve this, an effective NOP receptor selective antagonist, SB612, was used. The Fig. 3 clearly shows that the $\mathrm{E}_{\max }$ of P2, P3 and P5 were decreased in the presence of the antagonist. This demonstrates that our hybrid peptide ligands affected NOP receptor in a selective way.

Following in vitro biochemical studies, the pharmacological effects of the peptide variants were also investigated in mouse vas deferens bioassay. First, the ligands were tested alone to determine their agonist potency and efficacy. The studied ligands did not exhibit agonist activity, except for P2, in the case of which the $\mathrm{EC}_{50}$ was $426 \pm 76 \mathrm{nM}$, while it was over $10 \mu \mathrm{M}$ for all other peptides.

This result is surprising because the ligands proved to be promising in both binding and $\left[{ }^{35} \mathrm{~S}\right] \mathrm{GTP} \gamma \mathrm{S}$ tests based on the $\mathrm{K}_{\mathrm{i}}, \mathrm{EC}_{50}$ and $\mathrm{E}_{\max }$ values. Apart from this, the peptides are considered worthy of further investigations. Furthermore, it is important to note that, although P3 was also expected to achieve better agonist activity based on its $E_{\max }$ value (which was better than that of N/OFQ), despite our expectations, this ligand was inactive in the bioassay.

Only those ligands were expected to have antagonistic activity that contained RYYRIK at their $N$-terminal because RYYRIK itself acted as antagonist in previous $\left[{ }^{35} \mathrm{~S}\right] \mathrm{GTP} \gamma \mathrm{S}$ and mouse vas deferens experiments. Our results confirmed these expectations, as partial agonist ligands that did not contain RYYRIK, or did contain RYYRIK but not at their $N$ terminus (P9), proved to be inactive. P8 and P9 were found to be partial agonists in the $\left[{ }^{35} \mathrm{~S}\right] \mathrm{GTP} \gamma \mathrm{S}$ binding experiments, but they were completely inactive in the mouse vas deferens bioassay. In the radioligand binding studies only P9 exhibited a relatively high affinity, while P8 bearing two FGGF tandem 'message' motifs was practically inactive (Ki $>6 \mu \mathrm{M}$ ). One of the longest hybrid octadecapeptide variants P3 also showed high affinity in competition binding assays and high efficacy in $\left[{ }^{35} \mathrm{~S}\right] \mathrm{GTP} \gamma \mathrm{S}$ binding tests, but it was fully inactive in mouse vas deferens bioassay. These findings suggest that the use of a diversified experimental approach is better in characterizing novel synthetic analogues with previously unknown properties.

Summarizing the results, those ligands have been shown to be the most potent antagonists that carry RYYRIK on the $N$-terminus. These results suggest that the binding sites of RYYRIK and nociceptin on NOP receptor may overlap. However, it cannot be ruled out that RYYRIK binds to the NOP receptor at the TM2 domain. For P2 it can be established that, although it bound to NOP receptor with greater affinity than N/OFQ, and its $E_{\max }$ value was also greater than that of nociceptin, its $\mathrm{EC}_{50}$ was lower in both GTP and MVD tests than the $\mathrm{EC}_{50}$ of nociceptin (36 times and 7 times, respectively). It is worth mentioning that, despite the fact that P5 performed worse than P4 in the binding tests, the receptor activity test showed full agonist activity, and its potency was 190 times higher than that of P4. The mouse vas deferens bioassay also showed that P5 acts as a more effective antagonist than P4. This contradicts our hypothesis that the amidation of the $C$-terminus increases the affinity and biological activity of N/OFQ peptide analogues. The present data demonstrated that only one of our experimentally studied peptides, P2 retained the full agonist property, while those hybrids which contain the Dooley's sequence at their N-terminal (P1 and P4-7) exhibited partial agonism with significant antagonist activity. Ultimately, it would be useful to further investigate these peptides in in vivo experiments as well.

\section{References}

[1] J.R. Bunzow, C. Saez, M. Mortrud, C. Bouvier, J.T. Williams, M. Low, D.K. Grandy, Molecular cloning and tissue distribution of a putative member of the rat opioid receptor gene family that is not a $\mu, \delta$ or $\kappa$ opioid receptor type, FEBS Lett. 347 (1994) 284-288, https://doi.org/10.1016/0014-5793(94)00561-3.

[2] C. Mollereau, M. Parmentier, P. Mailleux, J.-L. Butour, C. Moisand, P. Chalon, D. Caput, G. Vassart, J.-C. Meunier, ORL1, a novel member of the opioid receptor family: cloning, functional expression and localization, FEBS Lett. 341 (1994) 33-38, https://doi.org/10.1016/0014-5793(94)80235-1.

[3] G. Calo, R. Guerrini, Medicinal chemistry, pharmacology, and biological actions of peptide Ligands selective for the nociceptin/orphanin FQ receptor, ACS Symp. Ser. 1131 (2013) 275-325, https://doi.org/10.1021/bk-2013-1131.ch015.

[4] R.K. Reinscheid, H.P. Nothacker, A. Bourson, A. Ardati, R.A. Henningsen, J.R. Bunzow, D.K. Grandy, H. Langen, F.J. Monsma, O. Civelli, Orphanin FQ: a neuropeptide that activates an opioidlike $G$ protein-coupled receptor, Science 270 (1995) 792-794 (Accessed 14 September 2016), http://www.ncbi.nlm.nih.gov/ pubmed/7481766.

[5] J.C. Meunier, C. Mollereau, L. Toll, C. Suaudeau, C. Moisand, P. Alvinerie, J.L. Butour, J.C. Guillemot, P. Ferrara, B. Monsarrat, Isolation and structure of the endogenous agonist of opioid receptor-like ORL1 receptor, Nature 377 (1995) 532-535, https://doi.org/10.1038/377532a0.

[6] O. Civelli, R.K. Reinscheid, Y. Zhang, Z. Wang, R. Fredriksson, H.B. Schiöth, G Protein-coupled receptor deorphanizations, Annu. Rev. Pharmacol. Toxicol. 53 (2013) 127-146, https://doi.org/10.1146/annurev-pharmtox-010611-134548.

[7] G. Calo', R. Guerrini, A. Rizzi, S. Salvadori, D. Regoli, Pharmacology of nociceptin and its receptor: a novel therapeutic target, Br. J. Pharmacol. 129 (2000) 1261-1283, https://doi.org/10.1038/sj.bjp.0703219.

[8] S. Lapalu, C. Moisand, H. Mazarguil, G. Cambois, C. Mollereau, J.C. Meunier, Comparison of the structure-activity relationships of nociceptin and dynorphin A using chimeric peptides, FEBS Lett. 417 (1997) 333-336 (Accessed 3 April 2018), http://www.ncbi.nlm.nih.gov/pubmed/9409745.

[9] G. Sundström, S. Dreborg, D. Larhammar, Concomitant duplications of opioid 
peptide and receptor genes before the origin of jawed vertebrates, PLoS One 5 (2010) e10512, , https://doi.org/10.1371/journal.pone.0010512.

[10] C. Mustazza, G. Bastanzio, Development of nociceptin receptor (NOP) agonists and antagonists, Med. Res. Rev. 31 (2011) 605-648, https://doi.org/10.1002/med. 20197.

[11] C.T. Dooley, C.G. Spaeth, I.P. Berzetei-Gurske, K. Craymer, I.D. Adapa, S.R. Brandt, R.A. Houghten, L. Toll, Binding and in vitro activities of peptides with high affinity for the nociceptin/orphanin FQ receptor, ORL1, J. Pharmacol. Exp. Ther. 283 (1997) 735-741 http://www.ncbi.nlm.nih.gov/pubmed/9353393.

[12] H. Berger, R. Bigoni, E. Albrecht, R.M. Richter, E. Krause, M. Bienert, G. Calo', The nociceptin/orphanin FQ receptor ligand acetyl-RYYRIK-amide exhibits antagonistic and agonistic properties, Peptides 21 (2000) 1131-1139 (accessed November 2, 2016), http://www.ncbi.nlm.nih.gov/pubmed/10998548.

[13] N.T. Zaveri, Nociceptin opioid receptor (NOP) as a therapeutic target: progress in translation from preclinical research to clinical utility, J. Med. Chem. 59 (2016) 7011-7028, https://doi.org/10.1021/acs.jmedchem.5b01499.

[14] L. Toll, M.R. Bruchas, G. Calo, B.M. Cox, N.T. Zaveri, Nociceptin/orphanin FQ receptor structure, signaling, ligands, functions, and interactions with opioid systems, Pharmacol. Rev. 034929 (Apr. (68)) (2016) 419-457, https://doi.org/10.1124/pr. 114.009209 Epub 2016 Mar 8. Review.

[15] P.R. Daga, N.T. Zaveri, Homology modeling and molecular dynamics simulations of the active state of the nociceptin receptor reveal new insights into agonist binding and activation, Proteins 80 (2012) 1948-1961, https://doi.org/10.1002/prot. 24077.

[16] R. Guerrini, G. Calo', A. Rizzi, C. Bianchi, L.H. Lazarus, S. Salvadori, P.A. Temussi, D. Regoli, Address and message sequences for the nociceptin receptor: a structure - activity study of nociceptin-(1 - 13)-peptide amide, J. Med. Chem. 40 (1997) 1789-1793, https://doi.org/10.1021/jm970011b.

[17] C.T. Dooley, R.A. Houghten, Orphanin FQ: receptor binding and analog structure activity relationships in rat brain, Life Sci. 59 (1996) PL23-PL29 (accessed August 13, 2018), http://www.ncbi.nlm.nih.gov/pubmed/8684262.

[18] C.T. Dooley, C.G. Spaeth, I.P. Berzetei-Gurske, K. Craymer, I.D. Adapa, S.R. Brandt, R.A. Houghten, L. Toll, Binding and in vitro activities of peptides with high affinity for the nociceptin/orphanin FQ receptor, ORL1, J. Pharmacol. Exp. Ther. 283 (1997) 735-741 (accessed June 5, 2018), http://www.ncbi.nlm.nih.gov/pubmed/ 9353393.

[19] C. Kawano, K. Okada, T. Honda, T. Nose, K. Sakaguchi, T. Costa, Y. Shimohigashi, Structural requirements of nociceptin antagonist Ac-RYYRIK-NH2 for receptor binding, J. Pept. Sci. 8 (2002) 561-569, https://doi.org/10.1002/psc. 415.

[20] B. Bes, J.-C. Meunier, Identification of a hexapeptide binding region in the nociceptin (ORL1) receptor by photo-affinity labelling with Ac-Arg-Bpa-Tyr-Arg-TrpArg-NH2, Biochem. Biophys. Res. Commun. 310 (2003) 992-1001 (Accessed 2
November 2016), http://www.ncbi.nlm.nih.gov/pubmed/14550303.

[21] N. Akuzawa, S. Takeda, M. Ishiguro, Structural modelling and mutation analysis of a nociceptin receptor and its ligand complexes, J. Biochem. 141 (2007) 907-916, https://doi.org/10.1093/jb/mvm100.

[22] G. Calò, A. Rizzi, G. Bogoni, V. Neugebauer, S. Salvadori, R. Guerrini, C. Bianchi, D. Regoli, The mouse vas deferens: a pharmacological preparation sensitive to nociceptin, Eur. J. Pharmacol. 311 (1996) R3-5 (Accessed 3 April 2018), http:// www.ncbi.nlm.nih.gov/pubmed/8884244.

[23] E. Guerrieri, J.R. Mallareddy, G. Tóth, H. Schmidhammer, M. Spetea, Synthesis and pharmacological evaluation of $\left[{ }^{3} \mathrm{H}\right] \mathrm{HS} 665$, a novel, highly selective radioligand for the kappa opioid receptor, ACS Chem. Neurosci. 6 (2015) 456-463, https://doi. org/10.1021/cn5002792.

[24] S.T. Nevin, L. Kabasakal, F. \&v\&t, G. Töth, A. Borsodi, Binding characteristics of the novel highly selective delta agonist, [3H]lle5 $\sim 6$ Deltorphin II, Neuropeptides (1994) (Accessed 2 August 2018), https://ac.els-cdn.com/0143417994900809/1s2.0-0143417994900809-main.pdf? tid = ae31bb22-9ff4-4eb1-b531 d9283ea7190d\&acdnat $=1533210404$ 09f3c1a01a1fc85bed0e2a6ce7d16009.

[25] A. Mollica, R. Costante, A. Stefanucci, F. Pinnen, G. Luisi, S. Pieretti, A. Borsodi, E. Bojnik, S. Benyhe, Hybrid peptides endomorphin-2/DAMGO: design, synthesis and biological evaluation, Eur. J. Med. Chem. 68 (2013) 167-177, https://doi.org/ 10.1016/j.ejmech.2013.07.044.

[26] A. Mollica, G. Zengin, S. Durdagi, R. Ekhteiari Salmas, G. Macedonio, A. Stefanucci, M.P. Dimmito, E. Novellino, Combinatorial peptide library screening for discovery of diverse $\alpha$-glucosidase inhibitors using molecular dynamics simulations and binary QSAR models, J. Biomol. Struct. Dyn. (2018) 1-15, https://doi.org/10. 1080/07391102.2018.1439403.

[27] E. Bojnik, J. Farkas, A. Magyar, C. Tömböly, U. Güçlü, O. Gündüz, A. Borsodi, M. Corbani, S. Benyhe, Selective and high affinity labeling of neuronal and recombinant nociceptin receptors with the hexapeptide radioprobe $[(3) \mathrm{H}] \mathrm{Ac}-$ RYYRIK-ol, Neurochem. Int. 55 (2009) 458-466, https://doi.org/10.1016/j.neuint 2009.04.014.

[28] J.R. Traynor, S.R. Nahorski, Modulation by mu-opioid agonists of guanosine-5'-O(3-[35S]thio)triphosphate binding to membranes from human neuroblastoma $\mathrm{SH}$ SY5Y cells, Mol. Pharmacol. 47 (1995) 848-54 http://www.ncbi.nlm.nih.gov/ pubmed/7723747 (Accessed 13 March 2017).

[29] A.Z. Rónai, I. Berzétei, S. Bajusz, Differentiation between opioid peptides by naltrexone, Eur. J. Pharmacol. 45 (1977) 393-394, https://doi.org/10.1016/00142999(77)90281-3.

[30] H.W. Kosterlitz, A.J. Watt, Kinetic parameters of narcotic agonists and antagonists, with particular reference to $\mathrm{N}$-allylnoroxymorphone (naloxone), Br. J. Pharmacol Chemother. 33 (1968) 266-276 http://www.pubmedcentral.nih.gov/articlerender. fcgi artid $=1570231 \&$ tool $=$ pmcentrez\&rendertype $=$ abstract. 